\title{
General Report on the Larval and Post-Larval Teleosteans in Plymouth Waters.
}

By

R. S. Clark, M.A., B.Sc.,

Naturalist to the Association, Plymouth Laboratory.

With 11 Figures in the Text.

CONTENTS.

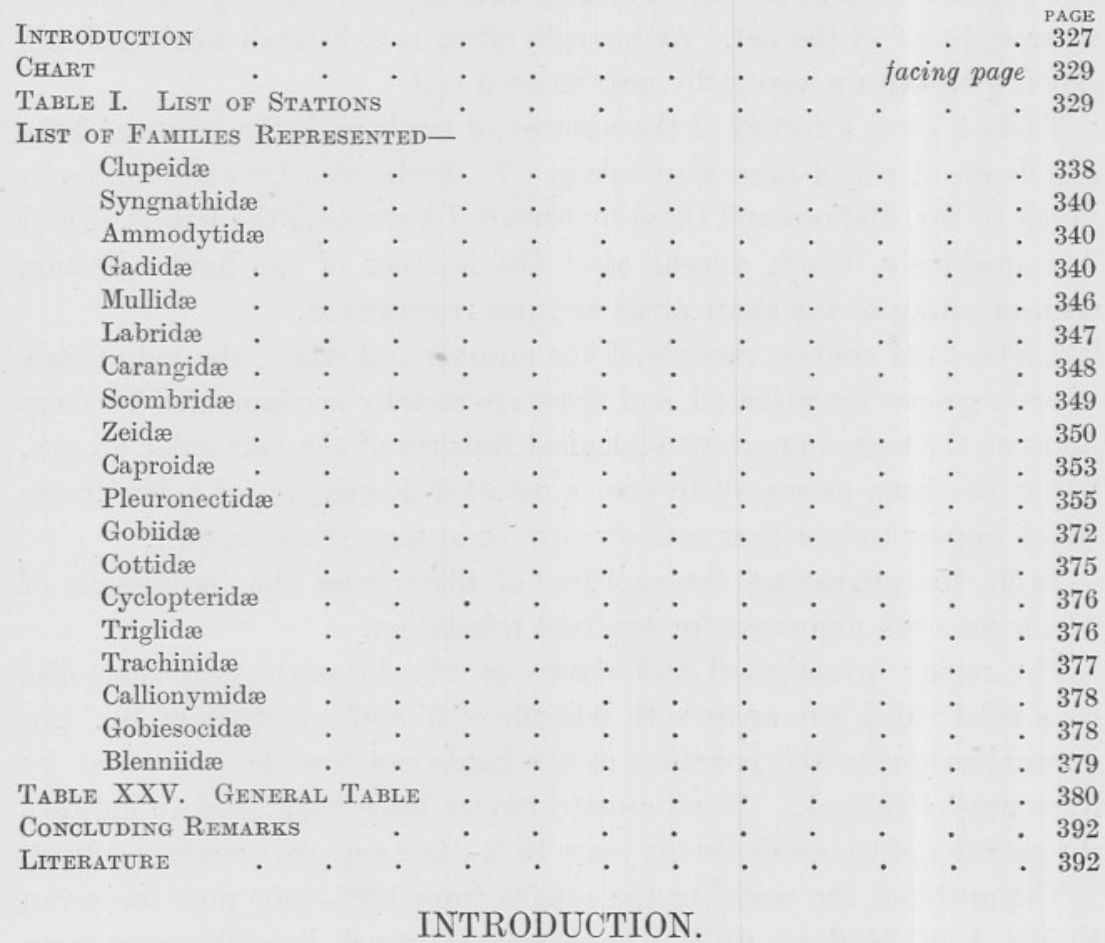

THE material on which the present report is based was collected by the Oithona from 1906 to 1909 inclusive, and during the latter half of 1913. Attention was directed particularly to the capture and determination of the post-larval fishes. The investigations during the first four years were carried out by Mr. A. E. Hefford, and his notes have been fully relied upon for the identification of the species. For the collecting and working out of the 1913 material I am directly and wholly responsible. 
The young-fish trawl was used throughout for the capture of the specimens, and hauls were taken at depths ranging from the surface to the bottom. This method of securing the young pelagic stages has proved so successful in the Danish researches that it has been followed at Plymouth, with equally good results.

All the nets used were constructed on the system of the Petersen young-fish trawl, and three qualities of material were used. These were coarse sacking ("Stramin "), with mesh $\frac{1}{16}$ " square; cheesecloth, with mesh $\frac{x}{32} "$ square; and mosquito netting. In order to withstand the strain of pulling on board, the last type was strengthened by an outer herring-net. It was noticeable that every sample taken with the first two types contained a mass of stringy substance, indicating considerable wear and tear of the net. As a result, these nets became weakened and quickly broken up, especially near the cod end.

Table 1 gives a record of the number of hauls with the locality, date, and depth at which these were taken. To distinguish between the hauls taken by Mr. Hefford and those by myself, I have used the letters $\mathrm{H}$ and A respectively, which appear after the number of the haul. Letters corresponding to the chart areas are also represented.

Tables 2-24 contain records of the number and size of the individuals of each species investigated, and these are usually accompanied by short notes on the more important biological features of the particular groups, but it has been necessary to give a detailed description of a few forms which appear to be either entirely new, or at most, little known.

Table 25 summarizes the captures of the species the individuals of which were too numerous for separate tabulation.

The region investigated and shown on the accompanying chart has been subdivided into areas with latitude of $5^{\prime}$ and longitude of $10^{\prime}$. An approximation to the positions of the hauls can thus be arrived at by reference to Table 1. Small crossed circles have been used to indicate the position of the hauls for the years 1906-1909 and plain circles for 1913 .

The credit of the work for the results from 1906-1909 must be given to Mr. A. E. Hefford, while I have received much helpful advice from Dr. Allen, Mr. C. Tate Regan, Dr. Kyle and Mr. E. T. Browne. In the preparation of this report $I$ have had the assistance of my colleague Mr. E. Ford, to whom I am also greatly indebted for the excellent series of drawings which are reproduced in the text and for the lettering in the chart. Further, Mr. Gossen has been a valuable help in the collecting and sorting out of the material. 


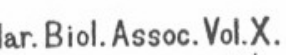

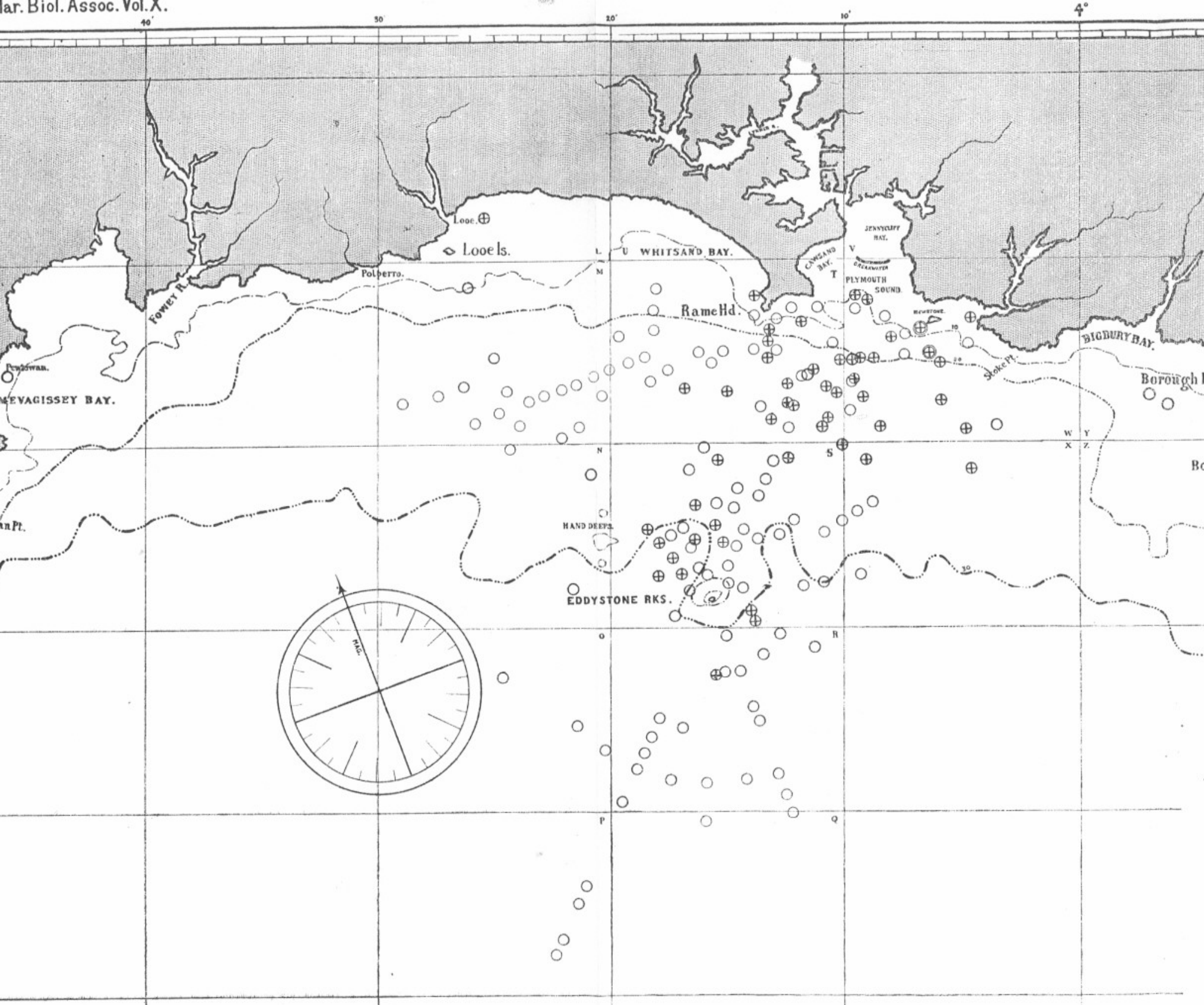

APPROACHES 'PLYMOUTH.

CHART ro ILLUSTRATE

HAULS Or YOUNG FISH TRAWL.

CARRIED OUT BY

S.S.01 THONA. 1906-09\&1913.

To face $p$. 329. 


\section{TABLE I. LIST OF STATIONS.}

Explanation of abbreviations. S.=surface. M.=midwater. B.=bottom. M.H.=midnight haul.

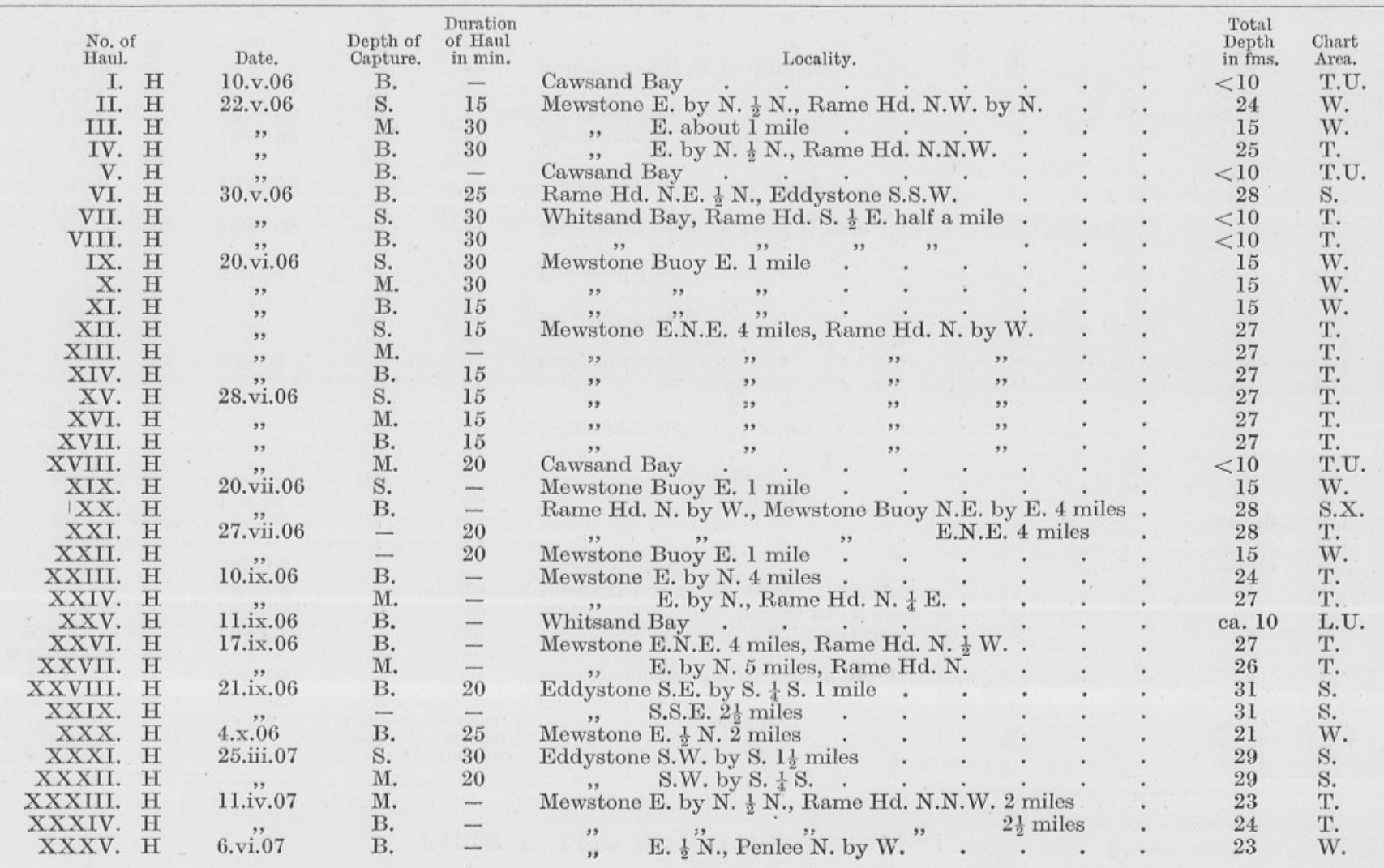


TABLE I. LIST OF STATIONS.-Continued.

Explanation of abbreviations. S. = surface. M. = midwater. B.=bottom. M.H.=midnight haul.

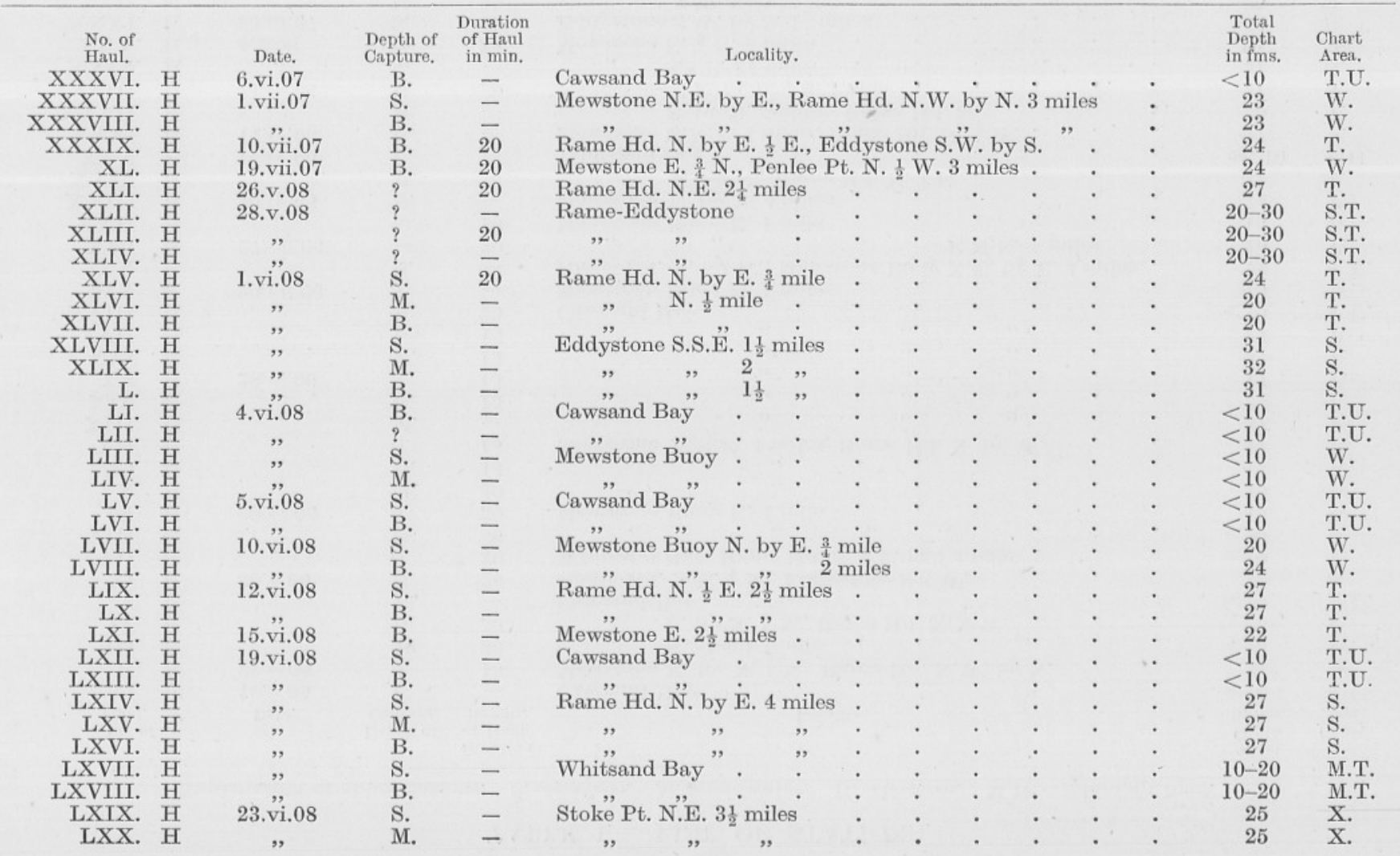


LXXI. H

LXXII. H

LXXIII. H

LXXIV. H

LXXV. H

LXXVI. H

LXXVII. H

LXXVIII. H

LXXIX. H

LXXX. H

LXXXI. H

LXXXII. H

LXXXIII. H

LXXXIV. H

LXXXV. H

LXXXVI. H

LXXXVII, H

LXXXVIII, H

LXXXIX. H XC. H XCI. H XCII. H

XCIII. H

XCIV. H

XCV. H

XCVI. H

XCVII. H

XCVIII. H

XCIX. H

C. H

CI. $\mathrm{H}$

CII. H

CIII. H

CIV. H

CV. H

CVI. H

CVII. H

CVIII. H

CIX. H

CX. H

CXI. H 23.vi.08

25. vi.08

30.vi.08

2. vii.08

15. vii. 08

"

20. vii. 08

21. vii.08

30.vii.08

6.viii.08

10.viii.08

17.viii.08

20. ".iii.08

26. viii.08

28.iv.09

3.v. 09

7.v. 09

13.v.09

24.v.09

2. vi.09

10.vi.09

22. "vi.09

25. "ैं. 09

29.vi.09

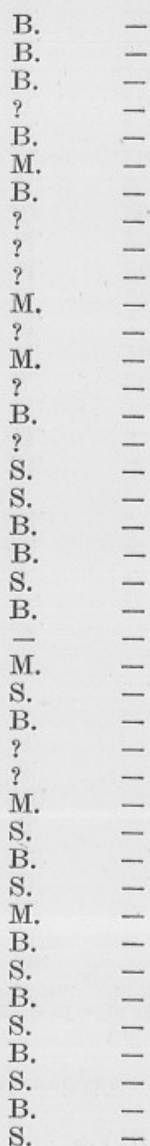

Stoke Pt. N.E. $3 \frac{1}{2}$ miles

Cawsand Bay

Looe Is. W.S.W. $1 \frac{1}{4}$ miles

Rame Hd. N.E. $2 \frac{1}{4}$ miles

Cawsand Bay

Mewstone E. by S. $\frac{3}{4}$ mile

Cawsand Bay

Mewstone E. by N. $1 \frac{3}{4}$ miles .

Eddystone S. by W. $2 \frac{1}{2}$ "miles

Mewstone Buoy N. by Ẅ. 1 mile

Eddystone N. by E. $\frac{1}{2}$ E. 2 miles

Mewstone N.E. 4 miles

Breakwater N.N.E. 1 mile

Mewstone N.E. 3 miles

Cawsand Bay

Mewstone N. 3 miles

Cawsand Bay

Bovisand Bay

Eddystone S.S.W. 2 miles

Whitsand Bay

Rame Hd. N̈. 2 miles

Whitsand Bay"

Cawsand Bay

Eddystone N’.W. by W. 1 mile

\begin{tabular}{cl}
25 & X. \\
$<10$ & T.U. \\
15 & M. \\
27 & T. \\
$<10$ & T.U. \\
12 & W. \\
12 & W. \\
$<10$ & T.U. \\
ca. 18 & W. \\
ca. 18 & W. \\
30 & S. \\
30 & S. \\
20 & W. \\
35 & R. \\
35 & R. \\
27 & X. \\
$<10$ & W. \\
26 & W. \\
26 & W. \\
$<10$ & T.U. \\
25 & W. \\
25 & W. \\
$<10$ & T.U. \\
$<10$ & T.U. \\
$<10$ & T.U. \\
$<10$ & T.U. \\
$<10$ & T.U. \\
$<10$ & W. \\
$<10$ & S. \\
$10-20$ & M.T. \\
$10-20$ & M.T. \\
26 & T. \\
26 & T. \\
26 & T. \\
$10-20$ & M.T. \\
$10-20$ & M.T. \\
$<10$ & T.U. \\
$<10$ & T.U. \\
$<10$ & T.U. \\
$<10$ & T.U. \\
31 & S. \\
\hline 10 &
\end{tabular}


TABLE I. LIST OF STATIONS.-Continued.

Explanation of abbreviations. S. $=$ surface. M. $=$ midwater. B. $=$ bottom. M.H.=midnight haul.

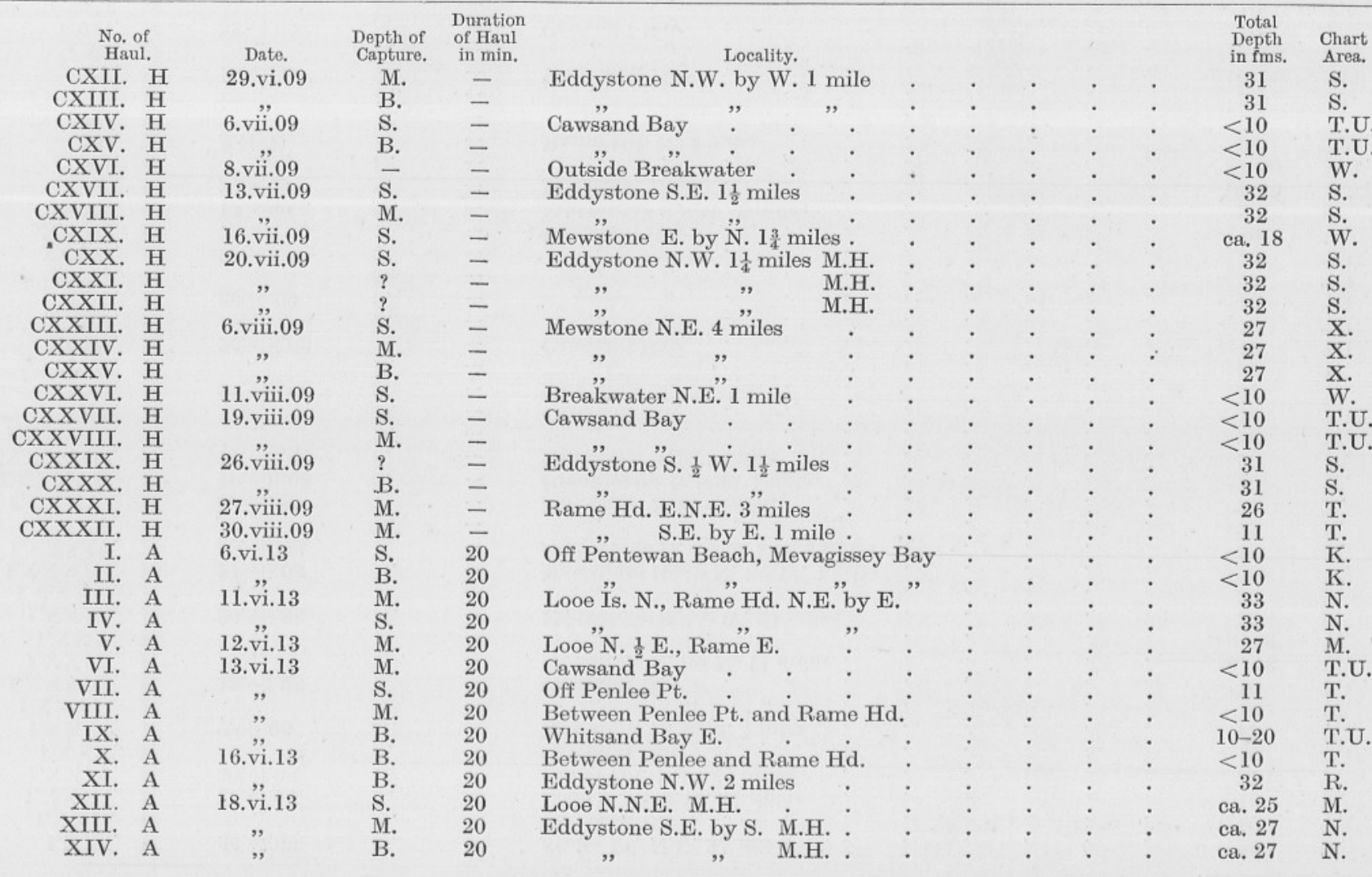




\begin{tabular}{|c|c|c|c|}
\hline XV. & A & 18.vi.13 & M. \\
\hline XVI. & A & 19.vi.13 & M. \\
\hline XVII. & A & $"$ & M. \\
\hline XVIII. & A & & $?$ \\
\hline XIX. & A & 20.vi.13 & M. \\
\hline $\mathrm{XX}$. & A & & s. \\
\hline XXI. & A & 24.vi.13 & S. \\
\hline XXII. & A & 27.vi.13 & M. \\
\hline XXIII. & A & 30.vi.13 & B. \\
\hline XXIV. & A & 3.vii.13 & M. \\
\hline XXV. & A & 7.vii.13 & B. \\
\hline XXVI. & A & 8.vii.13 & M. \\
\hline XXVII. & A & 10.vii.13 & S. \\
\hline XXVIII. & $\mathrm{A}$ & 11.vii.13 & M. \\
\hline XXIX. & A & & S. \\
\hline XXX. & A & 14.vii.13 & M. \\
\hline XXXI. & A & & s. \\
\hline XXXII. & A & 15.vii.13 & B. \\
\hline XXXIII. & A & & S. \\
\hline XXXIV. & A & 16.vii.13 & M. \\
\hline $\mathrm{XXXV}$ & A & 17.vii.13 & S. \\
\hline XXXVI. & A & 18.vii.13 & M. \\
\hline XXXVII. & A & 24.vii.13 & B. \\
\hline XXXVIII. & A & 24.vii.13 & M. \\
\hline XXXIX. & A & 25.vii.13 & S. \\
\hline XL. & A & 28.vii.13 & M. \\
\hline XLI. & A & ," & M. \\
\hline XLII. & A & ", & M. \\
\hline XLIII. & A & & S. \\
\hline XLIV. & A & 29.vii.13 & S. \\
\hline XLV. & A & , & B. \\
\hline XLVI. & A & & M. \\
\hline XLVII. & A & 30.vii.13 & S. \\
\hline XLVIII. & A & & B. \\
\hline XLIX. & A & 31.vii.13 & B. \\
\hline L. & A & ," & M. \\
\hline LI. & A & ", & M. \\
\hline LII. & A & & S. \\
\hline LIII. & A & 1.viii.13 & s. \\
\hline LIV. & A & 2.viii.13 & S. \\
\hline LV. & A & ", & S. \\
\hline
\end{tabular}

Off Rame Hd.

Rame Hd. N.W. i W. 2 miles Mewstone N.E. by E. 1 mile . Cawsand Bay

Between Mewstone and Stoke Pt. Eddystone $\frac{3}{4}$ mile W.

Rame E. by N. $6 \frac{1}{2}$ miles

Rame E. $\frac{1}{2}$ N. 5 miles .

Looe Eddystone .

Whitsand Bay E.

Bigbury Bay

Cawsand Bay

Looe Eddystone.

Whitsand Bay

Off Polperro

Off Looe

Rame E. 5 miles .

White Patch to New Ground Buoy, Plymouth Sound

Rame Hd. N. by W. $\frac{1}{2}$ W. 2 miles

Eddystone E.S.E.

Rame”N.E. by ${ }^{\prime \prime}$. 1 mile

Cawsand Bay

Outside Breakwater

Jennycliff Bay

Eddystone S. by W. $\frac{1}{2}$ mile

, S.E. $\frac{1}{2}$ mile .

Jennycliff Bay

E. 1 mile

Rame E. 7 miles

$$
\text { , } \quad 6 \text { miles } \text { miles } \text {. }
$$

Eddystone N. 2 miles M.H. .

$$
\text { , N. } 3 \text { miles M.H. . }
$$

\begin{tabular}{cl}
$10-20$ & T. \\
17 & T. \\
20 & W. \\
$<10$ & T.U. \\
$10-20$ & W. \\
29 & S. \\
26 & M. \\
27 & M. \\
$20-30$ & M. \\
$20-30$ & M. \\
$10-20$ & T.U. \\
$10-20$ & Y. \\
$<10$ & T.U. \\
$20-30$ & M. \\
$20-30$ & M. \\
$10-20$ & M.T. \\
$10-20$ & M.T. \\
ca. 20 & M. \\
$<10$ & L.M. \\
27 & M. \\
$<10$ & V. \\
23 & T. \\
ca. 30 & S. \\
ca. 30 & S. \\
25 & T. \\
$<10$ & T. \\
$<10$ & W. \\
$<10$ & V. \\
$<10$ & V. \\
ca. 29 & S. \\
ca. 25 & S. \\
31 & S. \\
$<10$ & V. \\
$<10$ & V. \\
27 & M. \\
27 & M. \\
27 & M. \\
26 & T. \\
36 & R. \\
ca. 35 & R. \\
38 & R. \\
& \\
\hline
\end{tabular}


TABLE I. LIST OF STATIONS.-Continued.

Explanation of abbreviations. S.=surface. M. $=$ midwater. $\quad$ B. $=$ bottom. M.H. $=$ midnight haul.

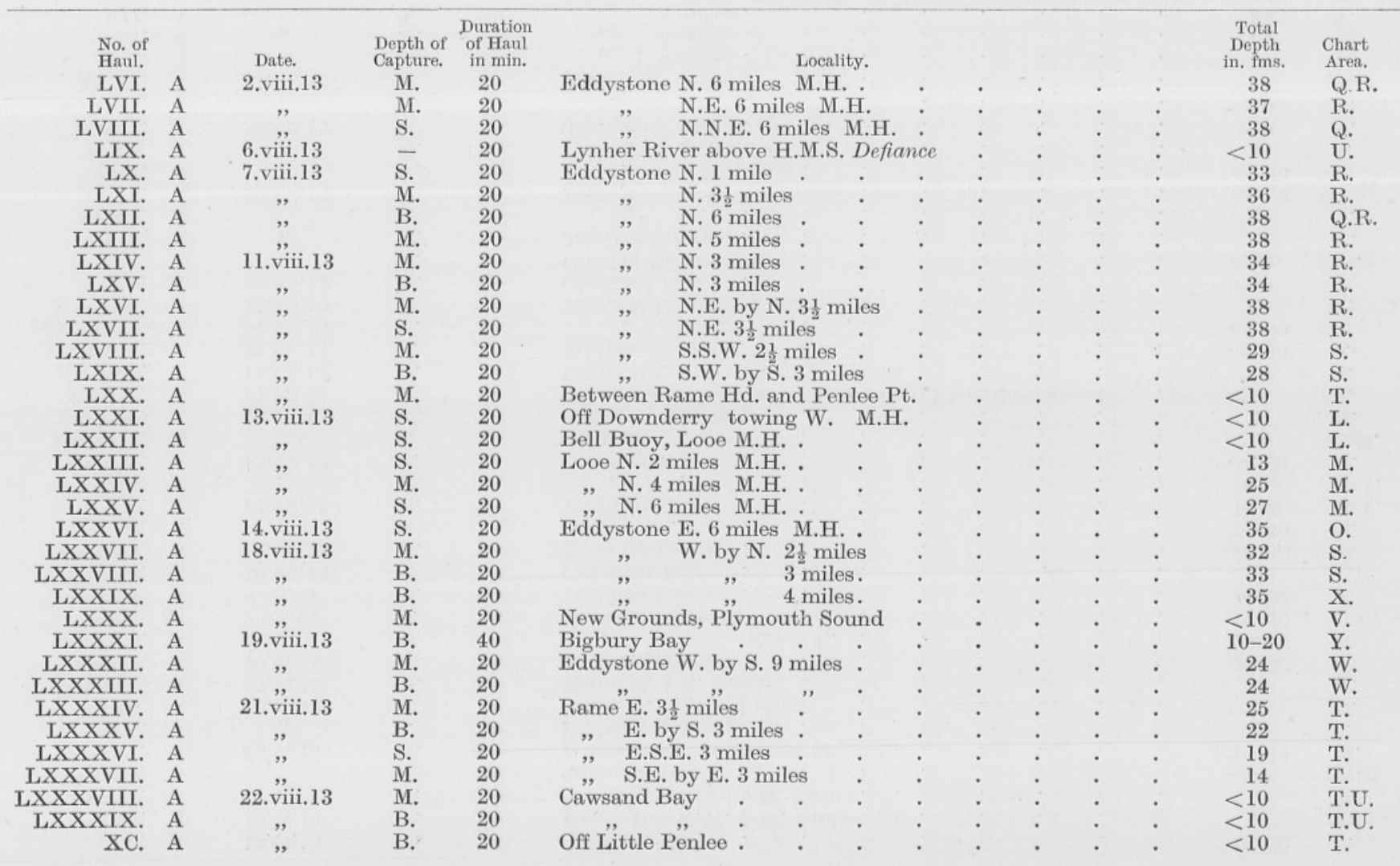




\begin{tabular}{|c|c|c|c|}
\hline XCI. & A & 25.viii.13 & s. \\
\hline XCII. & $\mathrm{A}$ & , & M. \\
\hline XCIII. & A & ," & M. \\
\hline XCIV. & $\mathrm{A}$ & ,, & M. \\
\hline XCV. & A & ," & M. \\
\hline XCVI. & A & ", & B. \\
\hline XCVII. & $\mathrm{A}$ & ," & B. \\
\hline XCVIII. & A & & M. \\
\hline XCIX. & $\mathrm{A}$ & 26.viii.13 & M. \\
\hline C. & A & 27.viii.13 & M. \\
\hline CI. & A & , & M. \\
\hline CII. & $\mathrm{A}$ & & M. \\
\hline CIII. & A & 29.viii.13 & M. \\
\hline CIV. & $\mathrm{A}$ & , & B. \\
\hline CV. & $\mathrm{A}$ & (3) & M. \\
\hline CVI. & A & & B. \\
\hline CVII. & A & 1.ix.13 & M. \\
\hline CVIII. & A & ", & M. \\
\hline CIX. & $\mathrm{A}$ & ," & B. \\
\hline CX. & A & & B. \\
\hline CXI. & A & 3.ix.13 & M. \\
\hline CXII. & $\mathrm{A}$ & ," & S. \\
\hline CXIII. & A & & S. \\
\hline CXIV. & $\mathrm{A}$ & 5.ix.13 & B. \\
\hline CXV. & A & 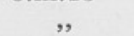 & M. \\
\hline CXVI. & $\mathrm{A}$ & ," & M. \\
\hline CXVII. & A & ", & M. \\
\hline CXVIII. & A & ", & M. \\
\hline CXIX. & A & & M. \\
\hline CXX. & A & 8.ix.13 & M. \\
\hline CXXI. & A & & B. \\
\hline CXXII. & $\mathrm{A}$ & ," & B. \\
\hline CXXIII. & A & ," & M. \\
\hline CXXIV. & A & & B. \\
\hline CXXV. & A & 9.ix.13 & M. \\
\hline CXXVI. & A & & B. \\
\hline CXXVII. & A & ,, & M. \\
\hline XXVIII. & A & ,, & M. \\
\hline CXXIX. & A & , & S. \\
\hline CXXX. & A & 10.ix.13 & M. \\
\hline CXXXI. & A & 11.ix.13 & M. \\
\hline
\end{tabular}

Eddystone N. 5 miles M.H. . $\quad$. $\quad$. $\quad$. $\quad$. 38

,"

N. by E. 5 miles M.H.

N.N.E. 5 miles M.H.

N.E. by N. 5 miles M.H.

N.E. 5 miles M.H.

N.E. by E. 5 miles M.H.

E.N.E. 5 miles M.H.

N.W. 3 miles

W.S.W. 5 miles

W. by S. $4 \frac{1}{2}$ miles

W. by S. 4 miles .

N.E. by N. $3 \frac{1}{2}$ miles

Eddystone N.E. $4 \frac{1}{2}$ miles

N.E. 6 miles
Rame"E. $3 \frac{1}{2}$ miles

N.E. 5
N.E. 6
miles
miles

" $\quad 5 \frac{1}{2}$ miles

Eddystone N.N.W. 2 miles M.H. :

$$
\begin{array}{ll}
, & \text { S.W. } 3 \text { miles } \\
, & \text { N.E. } 8 \frac{1}{2} \text { miles } \\
, & , \quad 9 \text { miles } \\
, & , \quad 10 \text { miles } \\
, & , \quad, \quad 10 \frac{1}{2} \text { miles } \\
, \quad & \quad 4 \text { miles }
\end{array}
$$

Rame" N. by ${ }^{W} .2$ miles

Eddystone"s.W. 4 miles

" S.W. by S. $2 \frac{1}{2}$ miles

Rame"Hd. E.N.E." $1 \frac{1}{2}$ miles .

$$
\begin{array}{ll}
" & \text { E. by N. } 3 \text { miles } \\
\text { ". } 4 \text { miles } & \text { E. } 6 \text { miles : }
\end{array}
$$

Looe N. 4 miles

Off Downderry

Eddystone S.W. 5 miles

R.
R.
R.
R.
R.
O.
O.
O.
R.
X.
X.
S..$~$
R.
R.
R.
R.
T.
M.T.
M.
M.
R.
R.
S.
P.
P.
P.
P.
R.
R.
T.
T.
S.
S.
S.
T.
T.
T.
M.
M.
L.
T.


TABLE I. LIST OF STATIONS.-Continued.

Explanation of abbreviations. S.=surface. M.=midwater. B.=bottom. M.H.=midnight haul.

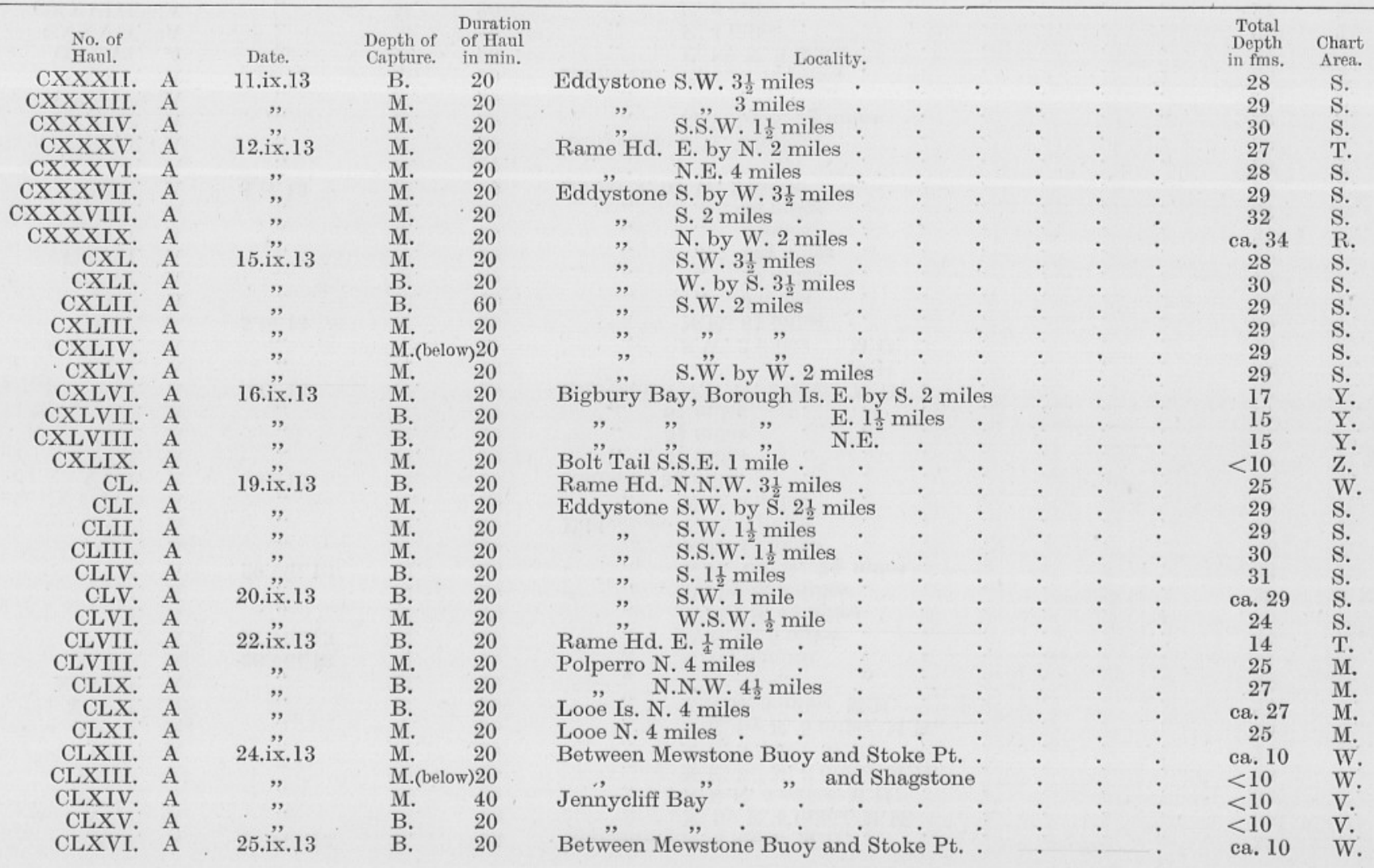




\begin{tabular}{|c|c|c|c|}
\hline CLXVII. & A & 25.ix.13 & M. \\
\hline CLXVIII. & A & ," & S. \\
\hline CLXIX. & A & ", & M. \\
\hline CLXX. & A & & B. \\
\hline CLXXI. & $\mathrm{A}$ & 26.ix.13 & M. \\
\hline CLXXII. & A & , & M. \\
\hline CLXXIII. & A & , & B. \\
\hline CLXXIV. & A & ", & B. \\
\hline CLXXV. & A & , & M. \\
\hline CLXXVI. & A & , & B. \\
\hline CLXXVII. & A & & S. \\
\hline CLXXVIII. & A & 29.ix.13 & M. \\
\hline CLXXIX. & A & & B. \\
\hline CLXXX. & $\mathrm{A}$ & 30.ix.13 & M. \\
\hline CLXXXI. & A & , & B. \\
\hline CLXXXII. & A & ", & M. \\
\hline CLXXXIII. & A & & M. \\
\hline CLXXXIV. & $\mathrm{A}$ & 1.x.13 & B. \\
\hline CLXXXV. & A & , & M. \\
\hline CLXXXVI. & A & & B. \\
\hline LXXXVII. & $\mathrm{A}$ & 10.x.13 & B. \\
\hline LXXXVIII. & A & 13.x. 13 & B. \\
\hline CLXXXIX. & A & $14 . x .13$ & B. \\
\hline CXC. & A &, & M. \\
\hline CXCI. & $\mathrm{A}$ & & M. \\
\hline CXCII. & A & 24.x.13 & M. \\
\hline CXCIII. & A & ,, & B. \\
\hline CXCIV. & A & & M. \\
\hline CXCV. & A & 27.x.13 & B. \\
\hline CXCVI. & A & & B. \\
\hline CXCVII. & A & 7.xi.13 & B. \\
\hline CXCVIII. & A & & M. \\
\hline CXCIX. & A & 13.xi.13 & B. \\
\hline CC. & A & & B. \\
\hline CCI. & A & ", & B. \\
\hline CCII. & A & & M. \\
\hline CCIII. & $\mathrm{A}$ & 26.xi.13 & B. \\
\hline CCIV. & A & , & B. \\
\hline & & & \\
\hline
\end{tabular}

Between Mewstone Buoy and Stoke Pt.. Eddystone W.'S.W. 3 miles .

Rame"E. 5 miles .

$$
\begin{aligned}
& \text {, } 5 \frac{1}{2} \text { miles. } \\
& \text {," } 6 \text { miles } \\
& \text { " } 4 \frac{1}{2} \text { miles. } \\
& \text { ", } 4 \text { miles. }
\end{aligned}
$$

Eddystone S.S.W. 2 miles S. by E. 2 miles Mewstone Buoy $\frac{3}{4}$ mile N.

",$"$.

$10-20$

Rame Hd. N.

Mewstone E. $\frac{1}{4}$ mile

Rame Ḧd. E. by N. 3 miles

, E. by s. 4 miles

Rame E. 6 miles .

, E. by N. 6 miles.

, E.N.E. $6 \frac{1}{2}$ miles .

Cawsand Bay

Mewstone S.E. by E. 2 miles .

Rame Hd. N. 1 mile

N.N.E. $2 \frac{1}{2}$ miles .

South of Breakwater

Penlee N.W. by W. 2 miles

Between Penlee and Rame Hd.

Eddystone S.W. 5 miles Breakwater S.W. by S. 3 miles

" $\quad$ S. 1 mile ca. 18

ca. 26

$10-20$

14

10

11

27

27

ca. 23

W.

W.

S.

$\mathrm{S}$.

M.

M.

M.

M.

M.

M.T.

T.

S.

S.

W.

W.

T.

T.

L.M.

L.M.

T.

W.

W.

T.

T.

27

26

ca. 28

$<10$

ca. 12

24

27

$<10$

ca. 15

$<10$

$<10$

27

29

31
T.

M.

M.

N.

T.U.

T.

T.

W.

W.

T.

T.

T.

S.

S. 


\section{CLUPEID AE.}

The Clupeoids, which are recorded in Table XXV, have not been fully determined specifically, though the material contains examples of three species, Clupea harengus L., C. sprattus L. and C. pitchardus Walb. A survey of Table 2 shows a maximum frequency in numbers during May and June, and the records for these two months are chiefly those of the Sprat, though Herring and Pilchard are also represented. The increase in numbers during September and October, after a decrease in July and August, was due largely to the capture of larval Pilchards, which were easily identified by the presence of an oil globule and segmented yolk. The occurrence of the eggs and early stages of $C$. pilchardus during a considerable part of the year raises the important question (which will be discussed in a later contribution) as to the periods of spawning for this species.

\section{SYNGNATHID Æ.}

TABLE III.

Record of Number and Size of Inidividuals.

\begin{tabular}{|c|c|c|c|c|c|c|c|c|c|}
\hline \multicolumn{2}{|c|}{$\begin{array}{l}\text { No. of } \\
\text { Haul. }\end{array}$} & \multirow{2}{*}{$\begin{array}{l}\text { Date. } \\
\text { 22.v.06 }\end{array}$} & \multirow{2}{*}{$\begin{array}{c}\text { Depth. } \\
\text { B. }\end{array}$} & \multicolumn{2}{|c|}{$\begin{array}{l}\text { S. acus. } \\
\text { No. Size mm. }\end{array}$} & \multicolumn{2}{|c|}{$\begin{array}{l}\text { S. rostellatus. } \\
\text { No. Size mm. }\end{array}$} & \multicolumn{2}{|c|}{$\begin{array}{l}\text { N. æquoreus. } \\
\text { No. Size mm. }\end{array}$} \\
\hline IV. & $\mathrm{H}$ & & & 3 & $13-15$ & - & - & - & - \\
\hline XVI. & $\mathrm{H}$ & 28.vi.06 & M. & - & - & 1 & 17 & - & - \\
\hline XXV. & $\mathrm{H}$ & 11.ix.06 & B. & - & - & 4 & $24-65$ & - & - \\
\hline XXX. & $\mathrm{H}$ & 4.x.06 & B. & - & - & 1 & 27 & - & - \\
\hline LXVIII. & $\mathrm{H}$ & 19.vi.08 & B. & 1 & 12 & - & - & - & - \\
\hline LXXVII. & $\mathrm{H}$ & 2.vii. 08 & B. & 1 & 19 & - & - & - & - \\
\hline LXXX. & $\bar{H}$ & 15.vii.08 & B. & 1 & 22 & - & - & - & - \\
\hline XCIV. & $\mathrm{H}$ & 26.viii.08 & M. & 2 & 23 & - & - & - & - \\
\hline CXIV. & $\mathrm{H}$ & 6.vii.09 & S. & 1 & $18 \cdot 5$ & - & - & - & - \\
\hline CXXVII. & $\mathrm{H}$ & 19.vii.09 & S. & - & - & 1 & 23 & - & - \\
\hline $\mathrm{x}$. & A & 16.vi.13 & B. & - & - & 1 & 20 & - & - \\
\hline XLI. & A & 28.vii.13 & M. & - & - & 1 & $14 \cdot 5$ & - & - \\
\hline XLII. & A & ," & M. & - & - & 1 & $25 \cdot 5$ & - & - \\
\hline XLIII. & A & & S. & - & - & 1 & 26 & - & - \\
\hline XLIV. & $\mathrm{A}$ & 29.vii.13 & - & - & - & - & - & 1 & 9 \\
\hline XLVI. & A & & M. & - & - & 1 & 14 & - & - \\
\hline XLVIII. & A & 30.vii.13 & B. & - & - & 2 & $21-29 \cdot 5$ & - & - \\
\hline LIV. & A & 2.viii.13 & S. & 1 & 56 & - & - & - & - \\
\hline LXXXI. & A & 19.viii.13 & B. & - & - & 1 & 33 & - & - \\
\hline LXXXVIII. & A & 22.viii.13 & M. & - & - & 3 & $17-20$ & - & - \\
\hline LXXXIX. & A & , & B. & - & - & 4 & $17 \cdot 5-22 \cdot 5$ & - & - \\
\hline XC. & A & , & B. & - & - & 17 & $18-33 \cdot 5$ & - & - \\
\hline XCI. & A & 25.viii.13 & S. & 1 & 43 & - & - & - & - \\
\hline CVIII. & A & 1.ix. 13 & M. & - & - & - & - & 1 & $14 \cdot 5$ \\
\hline CXXI. & A & 8.ix.13 & B. & 1 & 21 & - & - & - & - \\
\hline CXXI. & A & , & B. & - & - & - & - & 1 & 22 \\
\hline CLX. & A & 22. ix. 13 & B. & - & - & 1 & $36 \cdot 5$ & - & - \\
\hline CLXV. & A & 24.ix. 13 & B. & - & - & 3 & $16-42$ & - & - \\
\hline CLXXXIV. & A & 1.x.13 & B. & - & - & 1 & 14 & - & - \\
\hline CLXXXIX. & A & 14.x.13 & B. & - & - & - & - & 1 & 11 \\
\hline CXCVIII. & A & 7.xi.13 & M. & - & - & 1 & 27 & 1 & 15 \\
\hline
\end{tabular}


TABLE II. Monthly Summary of Clupeoids.

$$
\text { Explanation of Abbreviations }\left\{\begin{aligned}
\propto & =\text { Several thousands. } \\
\text { M. } & =\text { Many. } \\
\text { SIzE } & =\text { Length in mm. }
\end{aligned}\right.
$$

\begin{tabular}{|c|c|c|c|c|c|c|c|c|c|c|c|c|c|c|c|c|}
\hline \multicolumn{2}{|c|}{ MaRCH. } & \multicolumn{2}{|c|}{ APRIL. } & \multicolumn{2}{|c|}{ MAY. } & \multicolumn{2}{|c|}{ JUNE. } & \multicolumn{2}{|c|}{ JuLy. } & \multicolumn{2}{|c|}{ AUGUST. } & \multicolumn{2}{|c|}{ September. } & \multicolumn{2}{|c|}{ OCTOBER. } & No \\
\hline No. & Size. & No. & Size. & No. & Size. & No. & Size. & No. & Size. & No. & Size. & No. & Size. & No. & Size. & No. \\
\hline- & - & - & - & $\propto$ & $9-47$ & 112 & $9-22$ & 53 & $10 \cdot 5-24$ & - & - & 2 & $4 \cdot 5-18$ & 1 & 7 & - \\
\hline 24 & $3 \cdot 5-20$ & 20 & $5-14 \cdot 5$ & - & - & 3 & $9-12$ & 1 & 16 & - & - & - & - & - & - & 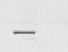 \\
\hline- & - & - & - & 55 & $4-21$ & M. & $6-24$ & 71 & $7-27$. & 3 & 20 & - & - & - & - & - \\
\hline- & - & 7 & $7-15$ & 14 & $12-27$ & 117 & $10-41$ & 127 & $7 \cdot 5-22 \cdot 5$ & 11 & $10-22.5$ & - & - & - & - & - \\
\hline - & - & - & - & - & - & 856 & $8-32 \cdot 5$ & 59 & $10-25$ & 90 & $9 \cdot 5-36$ & 264 & $3 \cdot 4-24$ & 486 & $3 \cdot 5-24$ & 3 \\
\hline 24 & $3 \cdot 5-20$ & 27 & $5-15$ & $\propto$ & $4-47$ & м. & $6-32 \cdot 5$ & 311 & $7-27$ & 104 & $8 \cdot 7-36$ & 266 & $3 \cdot 4-24$ & 487 & $3 \cdot 5-24$ & 93 \\
\hline
\end{tabular}

The measurements recorded in Tables 2 to 25 were taken from specimens preserved in $5 \%$ Formalin. 


\section{SYNGNATHIDE.}

\section{Syngnathus acus L. S. rostellatus Nilss. Nerophis oequoreus L.}

Larval and post-larval pipe-fishes occurred sparingly in the youngfish trawl material. They represent types of three species, of which the commonest is Syngnathus rostellatus Nilss. Most of the specimens were taken in bottom hauls close inshore, with a higher frequency from the mouth of the Sound inwards. A few were taken offshore, notably two older stages of $S$. acus, in surface hauls at midnight from 3 to 5 miles south of the Eddystone rocks.

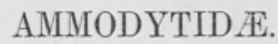

Ammodyies sp.

According to the records in Table 25, the frequency of the sand-eel larvæ and post-larvæ is greatest between the thirty and forty fathom lines, decreases slightly between the twenty and thirty, and is practically limited to a few records under twenty fathoms.

The summary (Table 4) shows a gradual increase in numbers until August, and a decrease in September, after which no individuals were captured. There is thus a comparatively dense spawning period in the middle months of the year, which seems to correspond to the period assigned to A. lanceolatus. Ehrenbaum considers the lesser sand-eel (A. tobianus) an earlier spawner. The period of maximum hatching for this species in the North Sea lies between January and March.

Both species are represented in the collection, but I have been unable to separate out the two forms as they show no obvious specific characters which would ensure accuracy in identification.

\section{GADID $\approx$.}

Gadus pollachius L. G. merlangus L. G. minutus O. F. Müller. G. luscus L.

These four species of Gadoids have been brought together in Table 5 . It will be seen that the maximum number of individuals lies in May and June, and that these are mostly whiting (G. merlangus). The pollack is an early spawner, but this may not account altogether for the scarcity of post-larval forms, especially when one considers the tolerable abundance of older stages in the littoral areas in summer. The records of $G$. minutus and G. luscus are important, and may help to throw some light on the spawning periods of these two closely allied species. G. luscus larvæ were taken in September, October, and November, 1913. Investigations were carried on at intervals during December of the same year, and during January and February, 1914, and eggs of this 
TABLE IV.

Monthly Summary of Ammodytes Sp.

\begin{tabular}{|c|c|c|c|c|c|c|c|c|c|c|c|c|c|c|c|}
\hline & \multicolumn{2}{|c|}{ March. } & \multicolumn{2}{|c|}{ APRIL. } & \multicolumn{2}{|c|}{ May: } & \multicolumn{2}{|c|}{ JUNE. } & \multicolumn{2}{|c|}{ JULy. } & \multicolumn{2}{|c|}{ AUGUST. } & \multicolumn{2}{|c|}{ SEPTEMRER. } & \\
\hline 1906 & No. & Size. & No. & Size. & $\begin{array}{l}\text { No. } \\
20\end{array}$ & $\begin{array}{l}\text { Size. } \\
6-29\end{array}$ & $\begin{array}{l}\text { No. } \\
40\end{array}$ & $\begin{array}{l}\text { Size. } \\
6 \cdot 5-18\end{array}$ & $\begin{array}{l}\text { No. } \\
17\end{array}$ & $\begin{array}{l}\text { Size. } \\
7-23\end{array}$ & No. & Size. & No. & $\begin{array}{l}\text { Size. } \\
15\end{array}$ & \\
\hline 1907 & 1 & $8 \cdot 5$ & 6 & $6 \cdot 5-12 \cdot 5$ & - & - & - & - & 12 & $13-22$ & - & - & - & - & \\
\hline 1908 & - & - & - & - & - & - & 84 & $6-23$ & 100 & $5-20$ & 26 & $5-19$ & - & - & \\
\hline 1909 & - & - & 1 & 12 & - & - & 16 & $10-32$ & 57 & $7-29$ & 18 & $5-22$ & - & - & \\
\hline 1913 & - & - & - & - & - & - & 51 & $14-104$ & 144 & $6-28$ & 462 & $4 \cdot 5-25$ & 13 & $5 \cdot 5-24$ & \\
\hline Sval & 1 & $8 \cdot 5$ & 7 & $6 \cdot 5-12 \cdot 5$ & 20 & $6-29$ & 191 & 6-104 & 330 & $5-29$ & 506 & $4 \cdot 5-25$ & 14 & $5 \cdot 5-24$ & \\
\hline
\end{tabular}


species were still abundant in the tow-nets, while larvæ were occasionally taken. Ova of $G$. minutus were not observed during this period, but it is possible that they may have been represented in the later February catches. There is evidence from the table that the bib spawns in February, March, and April, if not later.

In the four species of Gadus, frequency is high for the early pelagic stages beyond the twenty-fathom line, but gradually diminishes in intensity in the same area as the individuals get older.

\section{TABLE V.}

Record of Gadus Sp.

\begin{tabular}{|c|c|c|c|c|c|c|c|c|c|c|c|}
\hline No. of & & & & G. po & llachius. & G. $\mathrm{m}$ & erlangus. & & scus. & G. $\mathrm{m}$ & ninutus. \\
\hline Haul. & & Date. & Depth. & No. & Size. & No. & Size. & No. & Size. & No. & Size. \\
\hline II. & H & 22.v.06 & S. & 2 & $5-10$ & 11 & $5-17$ & - & - & - & - \\
\hline III. & H & , & M. & 1 & 10-15 & 158 & $5-15$ & 2 & $5-10$ & 3 & $5-15$ \\
\hline IV. & H & , & B. & - & - & 324 & $4-15$ & 7 & $5-10$ & 1 & 5 \\
\hline V. & $\mathrm{H}$ & & B. & - & - & 16 & $5-17$ & - & - & 2 & $8-11$ \\
\hline VI. & H & 30.v.06 & B. & 1 & $7 \cdot 5$ & 29 & 4-9 & - & - & 26 & $4-9$ \\
\hline VII. & $\mathrm{H}$ & , & S. & - & - & 5 & $7 \cdot 5-10$ & - & - & - & - \\
\hline VIII. & $\mathrm{H}$ & & B. & - & - & 1 & 9 & - & - & - & - \\
\hline IX. & $\mathrm{H}$ & 20.vi.06 & S. & - & - & 1 & 9 & - & - & - & - \\
\hline $\mathrm{X}$. & $\mathrm{H}$ & , & M. & - & - & 1 & $16 \cdot 5$ & - & - & - & $\overline{-}$ \\
\hline XI. & $\mathrm{H}$ & , & B. & - & - & 2 & 7 & - & - & 3 & $2 \cdot 5-$ \\
\hline XIII. & $\mathrm{H}$ & , & M. & - & - & 7 & $5-10$ & - & - & - & - \\
\hline XIV. & $\mathrm{H}$ & ק" & B. & - & - & 4 & $5-9$ & - & - & - & - \\
\hline XV. & $\mathrm{H}$ & 28.vi.06 & S. & - & - & 1 & 11 & - & - & - & - \\
\hline XVII. & $\mathrm{H}$ & $"$ & B. & - & - & 14 & $6-11$ & - & - & - & - \\
\hline XVIII. & $\mathrm{H}$ & . & M. & - & - & 2 & $7 \cdot 5-10$ & - & - & - & - \\
\hline XIX. & $\mathrm{H}$ & 20.vii. 06 & ? & - & - & 5 & $7 \cdot 5-8$ & - & - & - & - \\
\hline XX. & $\mathrm{H}$ & : & $?$ & - & - & 6 & $6-12 \cdot 5$ & - & - & 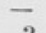 & 5 \\
\hline XXXI. & H & 25.iii.07 & S. & 4 & $4 \cdot 5-5 \cdot 5$ & - & - & - & - & 3 & $4 \cdot 5-6 \cdot 5$ \\
\hline XXXII. & $\mathrm{H}$ & & M. & 19 & $3-5$ & 2 & $3-4$ & - & - & 11 & $5-7$ \\
\hline XXXIII. & $\mathrm{H}$ & 11.iv.07 & M. & 15 & $4-7 \cdot 5$ & 20 & $4-8$ & 1 & $7 \cdot 5$ & - & - \\
\hline XXXIV. & $\mathrm{H}$ & & B. & 22 & $3 \cdot 5-6 \cdot 5$ & 19 & $3 \cdot 5-7 \cdot 5$ & 1 & $5 \cdot 5$ & - & - \\
\hline XXXV. & $\mathrm{H}$ & 6.vi.07 & B. & - & - & 72 & $5 \cdot 5-40$ & - & - & 2 & $10-15$ \\
\hline XXXVI. & $\mathrm{H}$ & ," & B. & - & - & 18 & $10-40$ & 1 & 9 & - & - \\
\hline XLII. & $\mathrm{H}$ & 28.v.08 & S. & - & - & - & - & - & - & 1 & 4 \\
\hline XLIII. & $\mathrm{H}$ & (1) & M. & - & - & 25 & $6-11$ & - & - & 7 & $6-8$ \\
\hline XLIV. & $\mathrm{H}$ & & B. & - & - & 14 & $7-11$ & - & - & 27 & $7-13$ \\
\hline XLV. & $\mathrm{H}$ & 1.vi.08 & S. & - & - & - & - & - & - & - & - \\
\hline XLVI. & $\mathrm{H}$ & ", & M. & - & - & 3 & 4-9 & - & - & - & - \\
\hline XLVII. & H & , & B. & - & - & 9 & $5-14 \cdot 5$ & - & - & - & - \\
\hline XLVIII. & $\mathrm{H}$ & , & S. & - & - & 1 & 12 & - & - & - & - \\
\hline XLIX. & $\mathrm{H}$ & , & M. & - & - & 1 & 12 & - & - & - & - \\
\hline L. & H. & & B. & - & - & 7 & $6-11$ & - & - & 3 & 6-9 \\
\hline LI. & $\mathrm{H}$ & 4.vi.08 & S. & - & - & 2 & 5 & 1 & 11 & - & - \\
\hline LII. & $\mathrm{H}$ & & B. & - & - & 3 & $3-4$ & 1 & $7 \cdot 8$ & - & - \\
\hline LV. & $\mathrm{H}$ & 5.vi.08 & S. & - & - & 8 & $5-15$ & - & - & - & - \\
\hline LVI. & $\mathrm{H}$ & & B. & - & - & 12 & $5 \cdot 5-14$ & 1 & $8 \cdot 5$ & - & - \\
\hline LVIII. & $\mathrm{H}$ & 10.vi.08 & B. & - & - & 23 & $6-14$ & - & - & - & - \\
\hline LIX. & $\mathrm{H}$ & 12.vi.08 & S. & - & - & - & - & - & - & - & - \\
\hline LX. & H & & B. & - & - & 22 & $5-11$ & 1 & 11 & 3 & $17-28$ \\
\hline LXI. & $\mathrm{H}$ & 15.vi.08 & B. & - & - & 21 & 6-9 & - & - & 36 & $30-48$ \\
\hline LXII. & $\mathrm{H}$ & 19.vi.08 & S. & - & - & 4 & $5-15$ & - & - & - & - \\
\hline LXIV. & $\mathrm{H}$ & , & M. & - & - & - & - & - & - & - & - \\
\hline LXV. & $\mathrm{H}$ & ", & B. & - & - & 9 & $4-16 \cdot 5$ & - & - & - & - \\
\hline
\end{tabular}


TABLE V.-Continued

Record of Gadus Sp.

No. of

Hanl.

LXVI. H

LXVIII. H

LXX. H

LXXI. H

LXXII. H

LXXIII. $\mathrm{H}$

LXXIV. H

LXXV. H

LXXX. H

XCV. H

XCVI. H

XCVII. $\mathrm{H}$

XCIX. H

C. $\mathrm{H}$

CI. $\mathrm{H}$

CII. $\mathrm{H}$

CIII. H

CIV. $\mathrm{H}$

CV. H

CVI. $\mathrm{H}$

CVIII. H

CIX. H

CX. H

CXIII. H

CXV. H

CXVI. H

CXVIII. H

CXXI. H

CXXII. H

CXXIV. H

I. A

III. A

V. A

VI. A

VII. A

VIII. A

IX. A

X. A

XII. A

XIII. A

XIV. A

XVI. A

XX. A

XXI. A

XXII. A

XXV. A

XXXIX. A

XLII. A

CXXIII. A

CLVII. A

CLXXI. A

CLXXVI. A

CLXXVII. A

CLXXXVII. A

CLXXXIX. A

$\begin{aligned} \text { CXCII. A } & \text { A } \\ \text { CXCIV. } & \text { A }\end{aligned}$
G. pollachius, G. merlangus.

Date. Depth. No. Size. No. Size.

19.vi.08 B. - - 20 5-11

,' B. -

B. - - $59-12.5$

$\begin{array}{llll} & \text { H. } & - & - \\ \text { B. } & - & -\end{array}$

25.vi.08 $\begin{array}{lll}\text { ". B. - } & \text { B. - }\end{array}$

30.vi.08

B. -

15. "vii. 09

B.

28.iv.08

B. - -

S. - -

3. v.09

13.v.09

24.v.09

2. vi.09

? - -

M. -

S. -

B. 1 -

S. - -

",

10. "ैi.09

M. -

B. 1

$4 \quad 10-12$

- - - - -

? $8-13 \quad-\quad-\quad 3 \quad 17-18$

$\begin{array}{lllll}1 & 7 \cdot 3 & - & - & -\end{array}$

$\begin{array}{lllll}2 & 11-14 & - & -\end{array}$

$\begin{array}{cccccc}6 & 5-8 & - & - & - & - \\ - & - & 1 & 4 & - & -\end{array}$

11

$6-5-10$

$11 \quad 5-15$

$20 \quad 6 \cdot 5-11$

$2 \quad 8-8 \cdot 5$

$117 \cdot 5-10$

$\begin{array}{rccccc}11 & 7 \cdot 5-10 & - & - & - & - \\ 4 & 6-12 & 1 & 7 & - & - \\ 11 & 6-12 & - & - & - & -\end{array}$

$26 \quad 7-13 \quad$

B. 11

22. vi.09

B. 13 23-4

25.vi. 09

B. -

29. vi.09

B. -

6.vii.09

8.vii.09

13.vii. 09

20.vii. 09

6. viii. 09

6.vi. 13

12. vi.13

13.vi.13

,

16. "vi.13

18.vi.13

,

19.vi.13

20.vi. 13

24.vi.13

27.vi.13

7.vii. 13

25.vii. 13

28.vii. 13

8.ix. 13

22.ix. 13

26.ix. 13

29.ix. 13

13.x.13

14.x.13

24.x. 13

26. ’xi.13

B. -

B.

i. =

M. -

B. -

M. -

S. -

B. -

M. -

M. -

S. -

M. -

B. -

B. -

S. -

M. -

B. -

M. -

S. -

S. -

M. -

B. - -

S. - -

M. -

M. - -

B. -

M. -

B. -

M. -

B. -

B. - - -

M. - - -

(5)

$\begin{array}{cccccc}2 & 9-13 & - & - & - & - \\ 5 & 6 \cdot 5-14 & - & - & - & - \\ 4 & 8-12 & - & - & - & -\end{array}$

$14 \quad 8-15$

3 7-7.5 - - -

- $=-\bar{E} \overline{1} \overline{54}$

- - - -

$19-126$

$12 \cdot 5-$ - - -

1
$12 \cdot 52$
$5 \cdot 6-7 \cdot 5$

- $-5-55$

$18.05---$

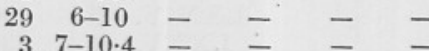

$627-12 \cdot 25---$

$257 \cdot 3-14-0-$

5 7-10.8

$28-8.2=-\overline{3} 11.69$

$39 \cdot 5-12=--$

$112 \cdot 39--$ -

1
6
$7-12 \cdot 6$

3 $6 \cdot 9-9 \cdot 5-=-$

$110=-$ -

$327-52 \cdot 5-$

$150-1-$

- $-1 \overline{8}=$

$8=$

$6 \cdot 23-$

$5 \cdot 76$
4

$4 \cdot 69-$

$4-4 \cdot 9--$

$4.89=-$ \begin{tabular}{llllll} 
& $7 \cdot 5-8$ & - & - & - & \\
\hline & - & $8-13 \cdot 5$
\end{tabular}

$3.35-$ - 


\section{GADID 2.}

\section{Molva molva L.}

Twenty post-larvæ of the common ling were taken in May and June. These ranged from $5 \mathrm{~mm}$. to $13.09 \mathrm{~mm}$. With the exception of five specimens taken in Cawsand Bay, all occurred beyond the twentyfathom contour line, and the majority of these between twenty and thirty fathoms, at no great distance from the shore, and off the entrance to the Sound. All the stages are similar to those described and figured by Schmidt in "Medd. fra Komm. for Havund. Serie Fiskeri," Bind II, 1906.

These records suggest a similar, though perhaps less extended, spawning period to that for the North Sea, which Ehrenbaum gives as March to May, with a maximum in April.

\section{TABLE VI.}

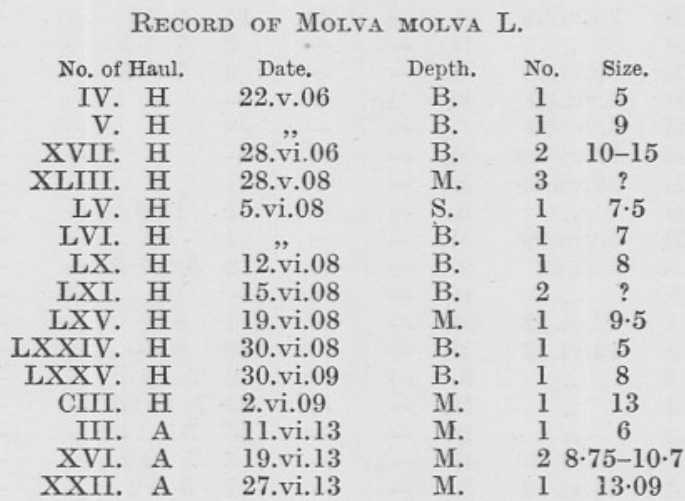

\section{GADID必.}

\section{Raniceps raninus $\mathrm{L}$.}

The records of the lesser forkbeard are confined to 8 specimens obtained from 13th August to 8th September, 1913. A spawning period from July to August is thus indicated. For the North Sea, Ehrenbaum* has given from middle of June to middle of August.

All were taken between the twenty and forty fathom contour lines. The occurrence of these early stages is interesting, when it is considered that the adult forkbeard is distinctly rare in the neighbourhood. Two

* Nordisches Plankton. Vol. II. Eier und Larven von Fischen. 1905. 
early post-larvæ of $4.5 \mathrm{~mm}$. bridge the gap between Ehrenbaum's $3 \mathrm{~mm}$. larva and Schmidt's* $5 \mathrm{~mm}$. early post-larva. The general outline of the fish (with the rounded profile of the head) resembles Schmidt's $5 \mathrm{~mm}$. specimen very closely. Pigment is slightly more pronounced, especially over the abdominal surface, where large stellate chromatophores of a rusty-brown colour are more closely packed on the dorsal part of this region. Chromatophores also appear on the suborbital region.

\section{TABLE VII}

\begin{tabular}{|c|c|c|c|c|}
\hline RECO & of Raniceps & RANINUS & $\mathrm{L}$ & \\
\hline $\begin{array}{l}\text { No. of Haul. } \\
\text { LXXIV. A }\end{array}$ & $\begin{array}{l}\text { Date. } \\
\text { 13.viii.13 }\end{array}$ & $\begin{array}{l}\text { Depth. } \\
\text { M. }\end{array}$ & $\begin{array}{l}\text { No. } \\
3\end{array}$ & $\begin{array}{l}\text { Size. } \\
4 \cdot 5-9\end{array}$ \\
\hline LXXIX. A & 18.viii.13 & B. & 1 & 17 \\
\hline XCV. A & 25.viii.13 & M. & 1 & 17 \\
\hline CII. A & 27.viii.13 & M. & 1 & $18 \cdot 5$ \\
\hline CXXII. A & 8.ix.13 & B. & 1 & $4 \cdot 5$ \\
\hline CXXVII. A & $9 . \mathrm{ix} .13$ & M. & 1 & $5 \cdot 5$ \\
\hline
\end{tabular}

GADID $\AA$.

Onos mustela L. O. tricirratus Bl. O. cimbrius L.

I can only identify with certainty one post-larva $3.75 \mathrm{~mm}$. in length as 0 . cimbrius. It was secured at the surface in haul $58 \mathrm{~A}$, on 2 nd August, 1913, 6 miles S.S.W. of the Eddystone rocks. It has the single typical post-anal bar and the long black ventrals as described by Ehrenbaum, $\uparrow$ and lies between his Fig. $f$ and Fig. g. Only two adult specimens have come under my notice. One, $22.5 \mathrm{~cm}$., was taken in a commercial beam-trawl on the outer Eddystone Grounds in November, 1912 ; the other, $15 \mathrm{~cm}$., in a mosquito-net attached to the shackle of the

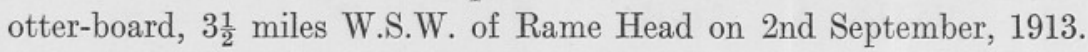
These have the first ray of the first dorsal fin extremely elongated.

Early post-larvæ of $O$. tricirratus were not observed, and only the later stages, with the three barbels developed, could be identified with accuracy.

O. mustela occurred from March to September with an intensity in June. The characters of these young stages are by no means obvious, and it is just possible that a few may belong really to 0 .tricirratus. The real difficulty in identifying the rocklings at Plymouth will be overcome when the early stages of $O$. tricirratus are worked out more fully.

* Medd. fra Komm. for Havund. Serie Fiskeri. Bind. II, Nr. 8. 1907.

† Nord. Plank. Vol. II, p. 280. 
TABLE VIII.

\section{Record of Onos Sp.}

\begin{tabular}{|c|c|c|c|c|c|c|}
\hline \multirow[b]{2}{*}{ No. of Haul. } & \multirow[b]{2}{*}{ Date. } & \multirow[b]{2}{*}{ Depth. } & \multicolumn{2}{|c|}{ o. mustela. } & \multicolumn{2}{|c|}{ o. tricirratus. } \\
\hline & & & No. & Size. & No. & Size. \\
\hline IV. $\mathrm{H}$ & 22.v.06 & B. & 1 & 5 & - & - \\
\hline XII. H & 20.vi. 06 & S. & 1 & 4 & - & - \\
\hline XIII. H & , , & M. & 1 & 10 & 1 & 30 \\
\hline XIV. $\mathrm{H}$ & & B. & 1 & 4 & - & - \\
\hline XVI. H & 28.vi.06 & M. & 2 & $2 \cdot 7-6$ & - & - \\
\hline XX. H & 20.vii. 06 & ? & $\overline{1}$ & 5 & - & - \\
\hline XXXIV. H & 11.iv. 07 & B. & 1 & $5 \cdot 5$ & - & - \\
\hline XXXIX. H & 10.vii.07 & B. & - & - & 1 & 32 \\
\hline XLV. H & 1.vi. 08 & S. & 4 & $8 \cdot 7-10 \cdot 5$ & - & - \\
\hline XLVI. H & , & M. & 1 & 7 & - & - \\
\hline XLVIII. $\bar{H}$ & & S. & 1 & $6 \cdot 8$ & - & - \\
\hline LV. $\mathrm{H}$ & 5.vi.08 & $\mathrm{S}$. & 1 & $4 \cdot 5$ & - & - \\
\hline LVIII. $\mathrm{H}$ & 10.vi.08 & B. & 2 & $5 \cdot 5-6$ & - & - \\
\hline LIX. H & 12.vi.08 & S. & 5 & $6-8$ & - & - \\
\hline LX. H & & B. & 1 & 6 & - & - \\
\hline LXXIV. H & 30.vi.08 & B. & 3 & $3-4$ & - & - \\
\hline LXXXII. H & 20.vii. 08 & M. & 1 & $5 \cdot 2$ & - & - \\
\hline CV. $\mathrm{H}$ & 10.vi.09 & S. & 2 & $3 \cdot 3-3 \cdot 4$ & - & - \\
\hline CXVI. H & 8.vii.09 & $?$ & $\overline{1}$ & 8.5 & - & - \\
\hline CXVIII. H & 13.vii.09 & M. & 1 & $7 \cdot 5$ & - & - \\
\hline CXXII. H & 20.vii.09 & ? & 1 & $6 \cdot 5$ & - & - \\
\hline IV. A & 11.vi.13 & S. & 1 & 7 & - & - \\
\hline XIII. A & 18.vi.13 & M. & - & - & 1 & 19 \\
\hline XIV. A & & B. & - & - & 1 & 25 \\
\hline XVII. A & 19.vi.13 & M. & 2 & $4 \cdot 2-4 \cdot 4$ & - & - \\
\hline XIX. A & 20.vi.13 & M. & 1 & $6 \cdot 8$ & - & - \\
\hline XX. A & & S. & - & - & 1 & $36 \cdot 5$ \\
\hline XXIII. A & 30.vi.13 & B. & 1 & $5 \cdot 39$ & - & - \\
\hline XXV. A & 7.vii.13 & B. & 1 & 19 & - & - \\
\hline XXXII. A & 15.vii.13 & S. & 1 & $4 \cdot 2$ & - & - \\
\hline XXXIX. A & 25.vii.13 & S. & 1 & 31 & - & - \\
\hline LIII. A & 1.viii.13 & S. & - & - & 2 & $25-25.5$ \\
\hline LVII. A & 2.viii. 13 & M. & - & - & 2 & $17-23$ \\
\hline LXIII. A & 7.viii. 13 & M. & 1 & $4 \cdot 89$ & - & - \\
\hline LXIV. A & 11.viii.13 & M. & - & - & . 1 & 28 \\
\hline LXXVIII. A & 18.viii.13 & B. & - & - & 1 & $37 \cdot 5$ \\
\hline CXXIX. A & 9.ix.13 & S. & 1 & 8 & - & - \\
\hline
\end{tabular}

\section{MULLID $A$.}

\section{Mullus surmuletus L.}

Records of post-larval red mullet were extremely few, and confined to June, July, and August. This indicates a spawning period from May to July, which corresponds to the known period of spawning for this species. There is unequal representation during the five years, but, owing to the scarcity of young forms recorded, no actual deduction can be made as to the yearly fluctuations of the adults. Their numbers seem to be clearly diminishing in the neighbourhood. 
TABLE IX.

Record of Muluus surmuletus L.

\begin{tabular}{|c|c|c|c|c|c|}
\hline No. of $\mathrm{Ha}$ & & Date. & Depth. & No. & Size \\
\hline XVII. & $\mathrm{H}$ & 28.vi.06 & B. & 2 & $5-6 \cdot 5$ \\
\hline XIX. & $\vec{H}$ & 20.vii.06 & $?$ & 1 & 6 \\
\hline XX. & H & & ? & 2 & $5-5 \cdot 5$ \\
\hline XXI. & $\mathrm{H}$. & 27.vii.06 & ? & 11 & $4 \cdot 5-5 \cdot 5$ \\
\hline XXII. & $\mathrm{H}$ & & $?$ & 2 & $5 \cdot 5-7$ \\
\hline CXIII. & $\mathrm{H}$ & 29.vi.09 & B. & 2 & 7 \\
\hline CXVII. & H & 13.vii.09 & S. & 1 & 7 \\
\hline CXX. & $\overline{\mathrm{H}}$ & 20.vii.09 & S. & 5 & $5-6$ \\
\hline CXXI. & $\mathrm{H}$ & & ? & 6 & $5 \cdot 5-7 \cdot 5$ \\
\hline CXXII. & $\mathrm{H}$ & & ? & 4 & $6-7 \cdot 7$ \\
\hline CXXIV. I & $\mathrm{H}$ & 6.viii.09 & M. & 4 & $4 \cdot 5-6 \cdot 5$ \\
\hline CXXV. & $\mathrm{H}$ & & B. & 3 & $5-6$ \\
\hline LVII. & A & 2.viii.13 & M. & 2 & $4 \cdot 69$ \\
\hline
\end{tabular}

\section{LABRID瓜.}

Labrus bergylta Asc. Ctenolabrus rupestris $\mathrm{L}$.

I have referred the pelagic young stages to the above two species which are recorded in Table 25. Ctenolabrus rupestris $\mathrm{L}$. is quite a distinct form and easily recognized by the help of Ehrenbaum's descriptions and figures in "Nordisches Plankton," Vol. I. Holt gives the spawning period from April to July, and this agrees with the occurrence of the species during the present investigations. The maximum frequency is in July; distribution is general in the area investigated.

The records of $L$. bergylta Asc. show a similar spawning period with an extension to August. The maximum is in June and July. It is possible that a few individuals of $L$. mixtus may be included in the list, but as the present state of our knowledge with regard to these two forms is extremely limited, the latter has meantime been excluded. The material seems to suggest two forms, one with a clear caudal peduncle region, the other with a slight continuation of the black stellate chromatophores along the ventral margin as indicated in Hefford's newly hatched larva of $L$. mixtus.* These two forms, however, show gradations of pigment.

* Journ. M.B.A. N.S., Vol. IX, No. 1. 1916. 
CARANGIDÆ.

Caranx trachurus $L$.

TABLE X.

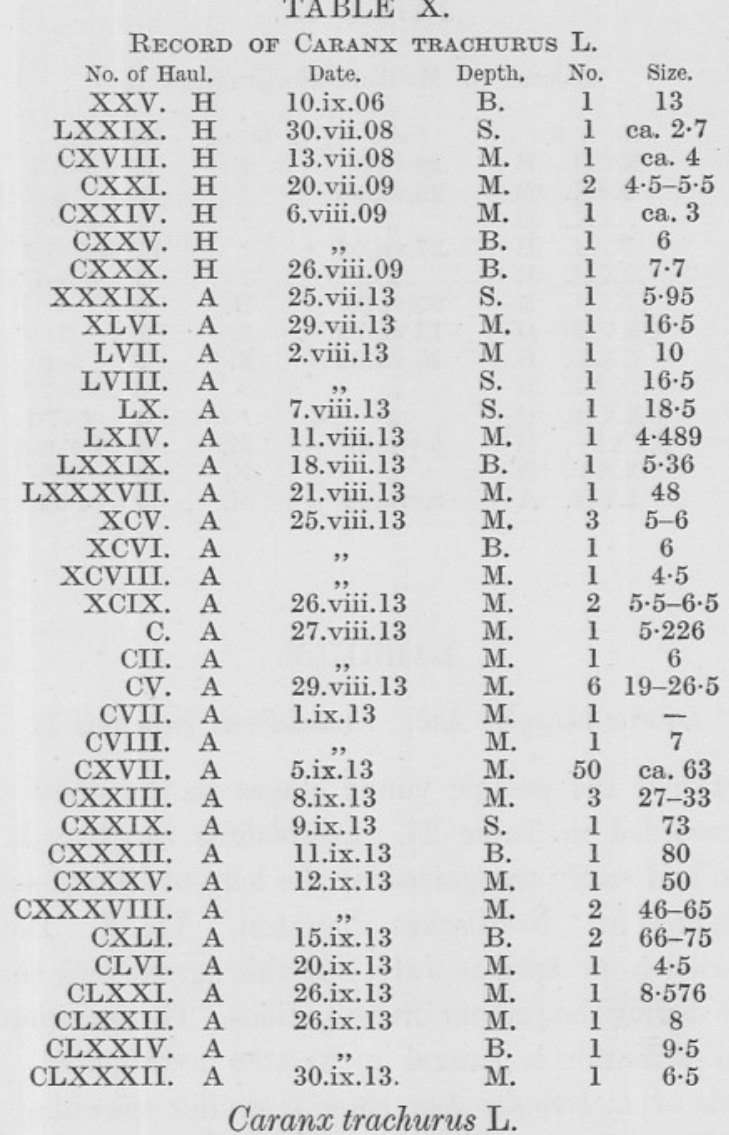

The spawning period of the scad has been given as May and June for the English Channel, but an extension at least to August is warranted by the present records, which indicate June to August. The frequency increases from the twenty-fathom contour line outwards. Young stages with fully developed adult characters were taken in September, generally in midwater or quite close to the surface, at lengths varying from 50 to $80 \mathrm{~mm}$. Several individuals from haul 117 between 60 and $70 \mathrm{~mm}$. in length were kept alive on board the Oithona, and transferred to the aquarium tanks. They fed ravenously on small pieces of worms and squid. Measured on 9th February, 1914, six months exactly after transference to the aquarium tanks, they gave measurements ranging from 105 to $130 \mathrm{~mm}$. They had thus almost doubled their length in half a year. Their age may be taken as 9 months, if June be considered the spawning month. 


\section{SCOMBRID $A$.}

Scomber scomber L.

Post-larval mackerel were exceedingly few. One hundred and eighteen specimens from 4 to $13 \mathrm{~mm}$. in length were taken during the period of investigation. These occurred during June and July, so that spawning in the neighbourhood must have begun in May in each year. The frequency in numbers is seen to decrease inshore, and to increase from the twentyfathom line outwards. Previous captures of the same stages (and these are by no means numerous) have been recorded chiefly at considerabledistances from land. It is thus highly probable, from the scarcity of individuals in the samples, that the early stages occur in greater numbers much farther out than the area investigated. Subsequent stages have been observed at Plymouth at lengths of about $100 \mathrm{~mm}$. One specimen of $200 \mathrm{~mm}$. was caught in a commercial beam-trawl west of the Eddystone rocks on 11th February, 1914. Scales were developed, which were obviously in their first year's growth, but on considering the length of the fish, the age must be about 1 year 9 months, if, according to Ehrenbaum, scales begin to develop during the second year.

TABLE XI.

RECORD OF SCOMBER SCOMBER L.

\begin{tabular}{|c|c|c|c|c|}
\hline $\begin{array}{l}\text { No. of Haul. } \\
\text { X. H }\end{array}$ & $\begin{array}{c}\text { Date. } \\
\text { 20.vi.06 }\end{array}$ & $\begin{array}{l}\text { Depth. } \\
\text { M. }\end{array}$ & No. & $\begin{array}{c}\text { Size. } \\
5 \cdot 5-7 \cdot 3\end{array}$ \\
\hline XI. H & , & B. & $i$ & 6 \\
\hline XII. H & , & S. & 2 & $7-7 \cdot 5$ \\
\hline XIII. H & , & M. & 4 & $6-7 \cdot 5$ \\
\hline XIV. H & & B. & 4 & ca. 7 \\
\hline XV. H & 28.vi.06 & S. & 6 & $7-11$ \\
\hline XVI. $\mathrm{H}$ & 28.vi.06 & M. & 3 & $7-7 \cdot 7$ \\
\hline XVII. H & & B. & 14 & $7-10 \cdot 5$ \\
\hline XIX. H & 20.vii.06 & S. & 1 & 7 \\
\hline XX. H & 27.vii.06 & $?$ & 2 & $4-7 \cdot 3$ \\
\hline XXII. H & & ? & 3 & $4-11$ \\
\hline LII. H & 10.vi.08 & S. & 1 & $7 \cdot 5$ \\
\hline LIX. $\bar{H}$ & 12.vi.08 & S. & 6 & $6-8$ \\
\hline LX. H & & B. & 1 & 6 \\
\hline LXI. H & 15.vi. 08 & B. & 2 & $7-7 \cdot 5$ \\
\hline LXIII. $\mathrm{H}$ & 19.vi.08 & B. & 1 & 7 \\
\hline LXIV. H & , & S. & 4 & $7 \cdot 5-10$ \\
\hline LXV. H & , & M. & 7 & $8-9$ \\
\hline LXVI. $\bar{H}$ & , & B. & 2 & ca. 7 \\
\hline LXIX. H & 23.vi.08 & S. & $\overline{2}$ & $8-9$ \\
\hline LXX. H & , & M. & 13 & $4 \cdot 5-12$ \\
\hline LXXI. H & & B. & 9 & $7-10$ \\
\hline CI. H & 29.vi.09 & S. & 3 & $9 \cdot 5-11.5$ \\
\hline CXVII. H & 13.vii.09 & S. & 1 & ca. 7 \\
\hline CXX. H & 20.vii.09 & S. & 8 & $7-9$ \\
\hline CXXI. H & ," & ? & 3 & $6 \cdot 5-7 \cdot 5$ \\
\hline CXXII. H & 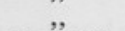 & ? & 3 & $6 \cdot 5-10$ \\
\hline III. A & 11.vi.13 & M. & 2 & $4 \cdot 9-5 \cdot 04$ \\
\hline XVI. A & 19.vi.13 & M. & 1 & $11 \cdot 5$ \\
\hline XXXIV. A & 16.vii. 13 & M. & 1 & 13 \\
\hline XXXIX. A & 25.vii. 13 & S. & 1 & $9 \cdot 45$ \\
\hline
\end{tabular}




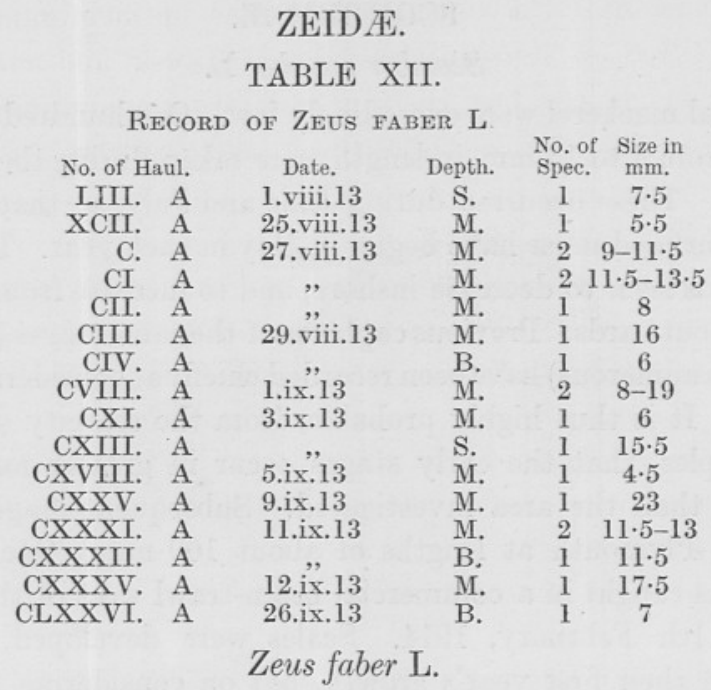

Our knowledge of the early post-larval stages of the John Dory seems to be restricted to the excellent descriptions of Schmidt in "Medd. fra Komm. for Havund. Serie Fiskeri," Bind II, No. 9, 1908. These post-larvæ ranged from $7 \frac{3}{4} \mathrm{~mm}$. to $19 \mathrm{~mm}$. in length, and were taken in the English Channel "almost all within the 100-metre curve" from the end of August to the middle of September. My own observations confirm and supplement those of the Thor. The series which I have recorded ranges from 4.5 to $23 \mathrm{~mm}$., and all were captured within the twenty and forty fathom contour lines, from the beginning of August to the end of September. Six of these from 4.5 to $7.5 \mathrm{~mm}$. represent younger stages than Schmidt's earliest post-larva of $7 \frac{3}{4} \mathrm{~mm}$., and I have described and figured two of these, one of $4.5 \mathrm{~mm}$. and one of $6 \mathrm{~mm}$. The remaining fourteen, from 8 to $23 \mathrm{~mm}$., agree in every respect so closely with Schmidt's series that nothing by way of description need be added here.

Fig. 1. Length $4: 5 \mathrm{~mm}$.

The maximum height is $2.04 \mathrm{~mm}$., and the length from snout to caudal fin $3.06 \mathrm{~mm}$. The highest point of the body lies directly over the posterior margin of the orbit, and in front of the first dorsal fin. The resemblance in shape to a parallelogram noted by Schmidt for his $7 \frac{3}{4} \mathrm{~mm}$. post-larva is roughly defined. The angle of the snout is very nearly $90^{\circ}$. The contour of the eye is not quite complete, but, so far as can be judged, its diameter is about equal to the length of the snout. The notochord is straight and extends about $\frac{2}{3}$ along the caudal fin, whose rays are only partially developed. The unpaired fins are still 
joined to the caudal by a continuance of their fin membranes. The rays of the first dorsal are indistinctly marked. Dorsal and anal interspines are clearly developed, but the fin rays are merely indicated. The ventrals are six-rayed, third largest and sixth shortest. They reach to the middle of the anal fin.

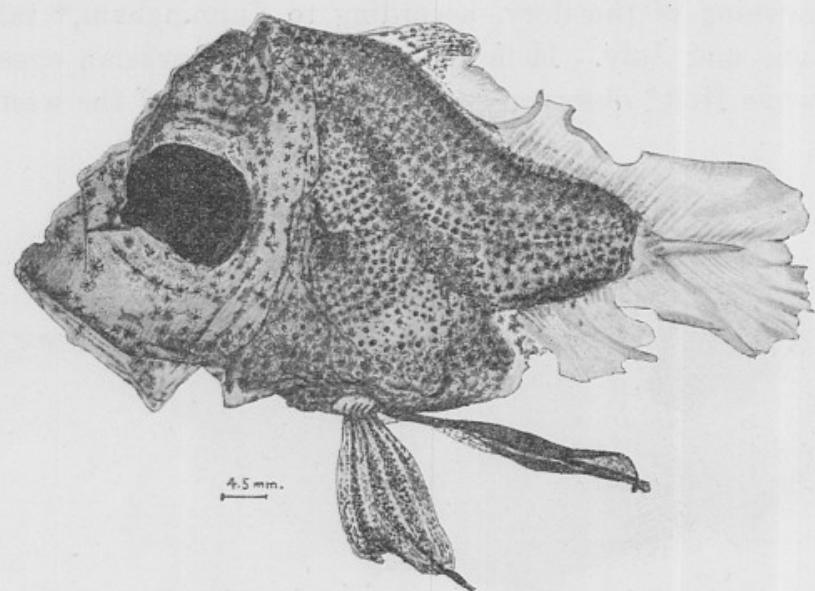

Fig. 1.-Zeus faber. Length $4.5 \mathrm{~mm}$. Oithona Station, CXVIII. A. 5th Sept., 1913. Total depth $37 \mathrm{fms}$. Midwater haul.

Del. E. Ford.

The whole surface of the body is covered with large black stellate chromatophores on a greenish background. These are intermingled with smaller chromatophores. The head is not so densely pigmented, and the interspaces between the chromatophores are larger. The ventral fins are densely pigmented with numerous large closely set chromatophores, giving the fins almost a black appearance. The pigment on the first dorsal fin is also evenly distributed, at least on the anterior half. No pigment occurs on the second dorsal, anal, and caudal fins.

Fig. 2. Length $6 \mathrm{~mm}$.

The maximum height is $3.004 \mathrm{~mm}$. and the distance to the caudal $4.78 \mathrm{~mm}$. (to end of body pigment). The highest point of the body is just in front of the first dorsal fin. The angle of the snout is slightly obtuse, and its length about equal to the diameter of the eye, the contour of which is still incompletely defined. The notochord is still straight or perhaps with a very slight upward tendency, caused by the hypural rays of the caudal being more developed. The unpaired fins are now separated from the caudal-fin membrane, and their rays are clearly, though not fully, defined.

The body pigment has spread on to the base of the dorsal and anal 
interspinous regions. Over the whole surface of the body there is a mixture of large and small stellate chromatophores, and smaller black dots. The unpaired fins are still unpigmented. The anterior half of the first dorsal fin has an aggregate of black chromatophores. The snout region has the least amount of pigment.

The spawning of the dory, according to Cunningham,* takes place during June and July. Hefford $\dagger$ obtained ripe ovarian eggs on 31st August, while Holt $\ddagger$ observed spent dories in June off the west coast of

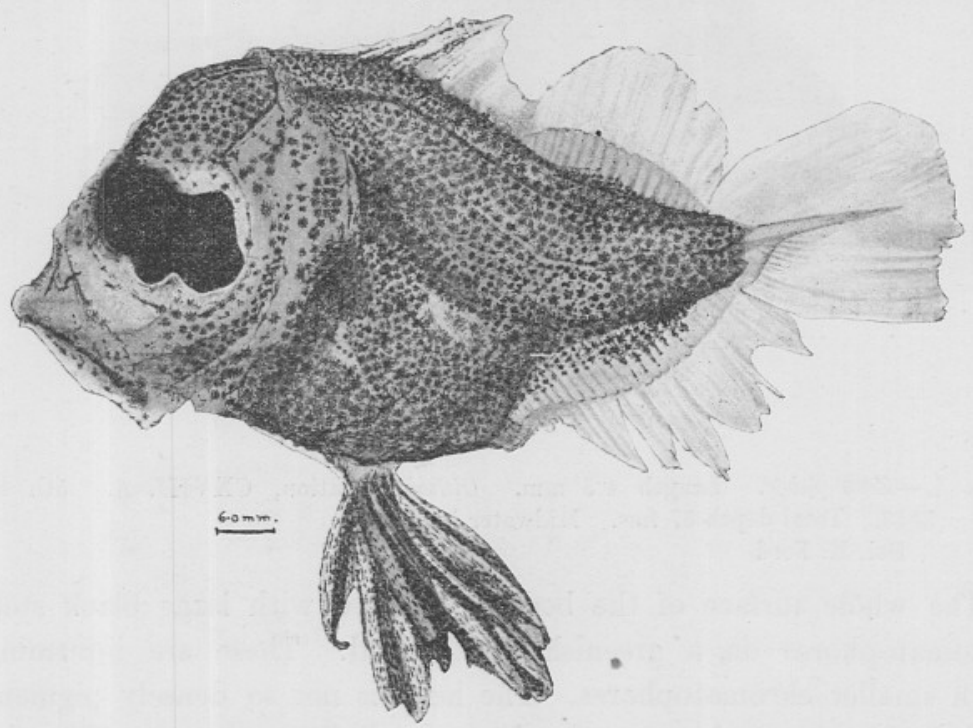

FIG. 2.-Zeus faber. Length $6 \mathrm{~mm}$. Oithona Station, CXI. A. 3rd Sept., 1913. Total depth 32 fms. Midwater haul.

Del, E, Ford.

Ireland. The post-larvæ recorded in the above table suggest a spawning period extending from July to the beginning of September, though it is probable from previous records that spawning may also occur in June.

Cunningham* worked out the rate of growth of the dory, and gave lengths of about $130 \mathrm{~mm}$. at the end of the first year, and about $280 \mathrm{~mm}$. at the end of two years. The usual length of the dory landed at the Plymouth Barbican is from 15 to 18 inches, which, as Cunningham remarks, "is probably not reached in less than three years." On examining the rings of growth on the opercular and hyomandibular bones (especially on the cerato-hyal), according to Heincke's method,§ I find the results agree with those of Cunningham, though not many specimens were examined. The material was secured by the Oithona in the Agassiz and otter trawls.
0 Group.
I Group.
II Group.
$<150 \mathrm{~mm}$.
ca. 150 -ca. $250 \mathrm{~mm}$.
ca. 250-ca. $350 \mathrm{~mm}$.

* Jour. M.B.A. N.S., 2. 1891-2.

$\dagger$ Journ. M.B.A. N.S., 9. 1910.

† Rep. Roy. Dublin Soc. 1892.

§ Intern. Meeres. Jahresbericht, 4-5. 


\section{CAPROID $\&$.}

\section{TABLE XIII.}

\begin{tabular}{|c|c|c|c|c|}
\hline RE & of CApros & APER & & \\
\hline No. of Haul. & Date. & Depth. & $\begin{array}{l}\text { No. of } \\
\text { Spec. }\end{array}$ & mm. \\
\hline XCIII. A & 25.viii.13 & M. & 1 & $5 \cdot 5$ \\
\hline XCVI. A &, & B. & 1 & $5 \cdot 76$ \\
\hline XCVIII. A & & M. & 1 & $3 \cdot 7$ \\
\hline XCIX. A & 26.viii.13 & M. & 1 & $4 \cdot 69$ \\
\hline CXVIII. A & 5.ix. 13 & M. & 2 & $3 \cdot 4-4$ \\
\hline CXXIII. A & 8.ix.13 & M. & 1 & $3 \cdot 5$ \\
\hline CLII. A & 19.ix.13 & M. & 3 & $3 \cdot 3-5 \cdot 5$ \\
\hline CLXXIV. A & 26.ix. 13 & B. & 1 & 6 \\
\hline
\end{tabular}

Capros aper $\mathrm{L}$.

The capture of eleven specimens, $3 \cdot 3$ to $6 \mathrm{~mm}$. in length, of the Cuckoo (as it is known locally in the adult state) between the twenty and forty fathom contour lines within a short radius of the Eddystone rocks, from

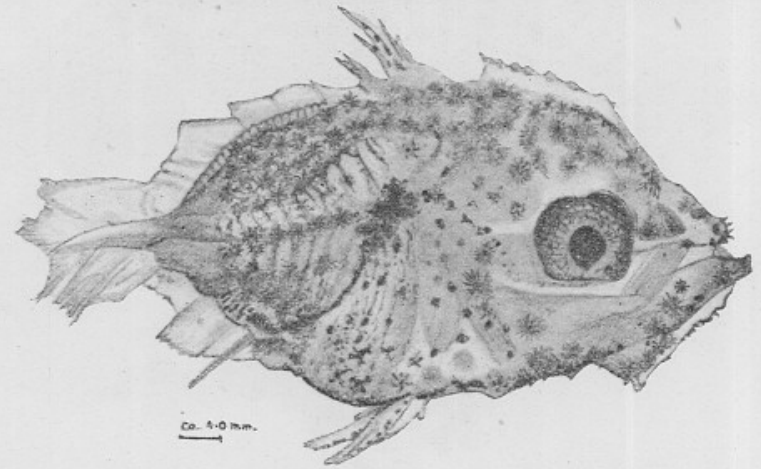

FIG, 3.-Capros aper. Length ca. $4 \mathrm{~mm}$. Oithona Station, CXVIII. A. 5th Sept, 1913. Total depth 37 fms. Midwater haul.

Del. E. Ford.

the end of August to the end of September, helps to add considerably to our knowledge of the early developmental stages of this species. So far as I am aware, only the eggs and resulting larvæ are known through the researches of Cunningham* and Holt, $\uparrow$ and one post-larva $15 \frac{1}{4} \mathrm{~mm}$. in length described by Schmidt. $\ddagger$ Thus, between Holt's $2.86 \mathrm{~mm}$. larva and Schmidt's $15 \frac{1}{4} \mathrm{~mm}$. post-larva nothing is known. My specimens are all early post-larvæ, but, unfortunately, they are too badly damaged to give a complete descriptive series. However, I have described and figured one of $4 \mathrm{~mm}$. and one of ca. $5 \mathrm{~mm}$. Zeus faber, the most nearly allied form, differs so markedly in its post-larval characteristics that there can be no confusing its early stages with those of $C$. aper.

* Journ. M.B.A. N.S., Vol. I. 1889-90.

† Annales du Musée d'Histoire Nat. de Marseille, Tome V, 2.

* Medd. fra Komm. for Havund. Serie Fisk., Bind II. 
In the latter species, orange-red pigment is already developed in specimens of $4 \mathrm{~mm}$. (on the abdominal region), while a distinct structural feature of Capros post-larvæ is the large number of small spines which cover practically the whole surface of the fish, and appear more markedly round the marginal outline. Two specimens were cleared and mounted. Each had about 22 vertebræ.

\section{Fig. 3. Length $4 \mathrm{~mm}$.}

The maximum height, measured along a vertical just in front of the first dorsal and anal fins, is $1.7 \mathrm{~mm}$., and the distance from tip of snout to

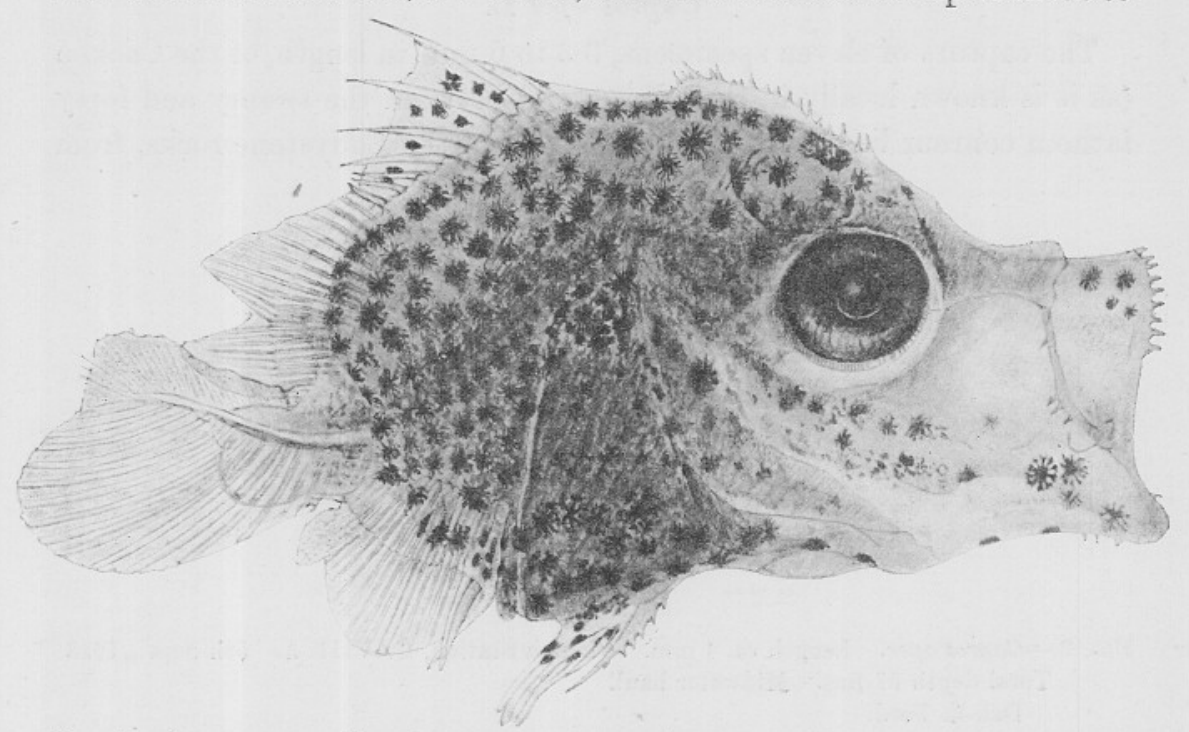

Fig. 4.-Capros aper. Length $6 \mathrm{~mm}$. Oithona Station, CLII. A. 19th Sept., 1913. Total depth 29 fms. Midwater haul. Del. E. Ford.

base of caudal fin is $3.2 \mathrm{~mm}$. The longitudinal axis runs through the middle of the eye. The angle of the snout is very nearly $90^{\circ}$-if anything less: its length is about equal to the longitudinal diameter of the eye, the contour of which is still incomplete. The rhomboidal form of the fish is well marked. Small tooth-like spines are prominent on the snout, chin, and profile of the head. The second dorsal and anal fin rays are just beginning. Hypurals are developed on the caudal. The first dorsal has the spiny rays moderately developed. As yet. the dorsal and anal fins are both joined by a membrane to the caudal. The notochord is straight. Dorsal and anal interspines are developed. The ventral fins are well developed, and reach back almost to the beginning of the analfin region. Number of vertebræ ca. 22 . 
Orange-red pigment, over which occur splashes of bright red, is present on the anterior dorsal half of the abdominal region, while yellow pigment occurs on the rest of the body and very faintly in small patches on the head. A dense aggregate of dark pigment marks off the posterior margin of the abdominal region, beginning just above the longitudinal axis and extending as a line of dark chromatophores to the origin of the anal fin. Large brownishblack stellate chromatophores are spread over the dorsal half of the head and body, leaving a clear space in front of the base of the caudal fin. These large chromatophores are continued across the body post-anally, along the lower part of the abdomen and the ventral margin to the tip of the snout. A few black dots are scattered over the red pigment of the abdominal region. The orbital region, especially the suborbital, is practically devoid of pigment. No pigment is visible on the second dorsal, caudal, and anal fins, while a few dark chromatophores appear on the first dorsal and ventral fins.

Fig. 4. Length $6 \mathrm{~mm}$.

The maximum height is contained a little more than twice in the total length : length to caudal fin about $1 \frac{1}{6}$ times. The snout is slightly concave above and below as in the adult; its length is about equal to the diameter of the eye. The marginal row of spines in front of the first dorsal fin is very prominent. Similar rows are present on the præmaxillary region and along the spiny ray of the ventral fin. The second dorsal and anal fins are separated from the caudal. Their rays are not fully developed posteriorly. The spines of the first dorsal fin are strong and well developed; nine can be counted. The tip of the notochord is turned upwards and the caudal rays well advanced. The dorsal membrane of the caudal is still fairly large.

The general arrangement and colour of the pigment is much the same as in the previous specimen, though the reddish patch has extended forward on to the orbital region. The colour is generally redder, owing to the presence of a larger number of bright red splashes.

\section{PLEURONECTID $Æ$.}

Pleuronectes limanda L. (common dab). P. flesus L. (flounder). P. microcephalus Donov. (merry-sole).

Records of post-larval $P$. platessa are absent from the tables, though the eggs were observed fairly frequently during December, 1913, and January and February, 1914. They appeared in the tow-nets in the latter part of December, 1913, and continued to be observed during 
January and February of this year, though less frequently in February. The maximum was in January. The diameters of the eggs varied from 1.809 to $2.07 \mathrm{~mm}$. One newly hatched larva measured about $6.9 \mathrm{~mm}$. These eggs were nearly all secured in inshore areas in Bigbury Bay and off the entrance to the Sound in quite shallow water.

Post-larval dabs are distributed generally over the area investigated, though they occur in greater numbers between the twenty and thirty fathom lines. The flounder shows a higher frequency in inshore areas, while post-larvæ of the merry-sole increase in intensity with the distance from land. The maximum frequency for post-larvæ of the dab lies in May, of the flounder in April and May, and of the merry-sole in June.

A specimen of $P$. microcephalus of $11 \mathrm{~mm}$. shows no sign of metamorphosis, whilst in one of $12.5 \mathrm{~mm}$. metamorphosis has commenced (cf. Kyle, * p. 48, footnote).

\section{PLEURONECTIDAE. Sub-fam. Вотнімж. Arnoglossus sp.}

An examination of several hundred adult specimens taken in the Oithona's otter trawl in 1913 proves conclusively, with the help of Kyle's work,* the existence of three main species of the genus Arnoglossus in the neighbourhood of Plymouth. Kyle relied on four principal features for his segregation of the species, which he classified as :-

(1) Structural Characters.

(2) Dimensional ,

(3) Numerical ,

(4) Post-larval Characteristics.

These are sufficiently clear and comprehensive to make the identification of the three species at Plymouth comparatively easy. A. laterna. Walb. and A. imperialis Raf. (A. lophotes Günther) occur most abundantly, while $A$. thori Kyle is comparatively rare.

The character of the first few dorsal rays, the length of the head, diameter of eye, and length of ventrals seem quite good enough to separate the three species already noted.

The larval and post-larval material will be reported on more fully in a later communication. There are considerably over a thousand specimens, which represent nearly all the stages up to the metamorphosed condition. A survey of Table 25 shows a maximum frequency in August and September, which, with the records for the earlier months, suggests a prolonged

* Rept. Danish Ocean. Exped., 1908-10. No. 2 (1913). 


\section{PLEURONECTIDE.}

\section{TABLE XIV.}

Record of Pleuronectes sp.

\begin{tabular}{|c|c|c|c|c|c|c|c|c|}
\hline \multirow[b]{2}{*}{ No, of Haul. } & \multirow{3}{*}{$\begin{array}{l}\text { Date. } \\
\text { 10.v.06 }\end{array}$} & \multirow{3}{*}{$\begin{array}{l}\text { Depth, } \\
\text { B. }\end{array}$} & \multicolumn{2}{|c|}{ P. limanda. } & \multicolumn{2}{|c|}{ P. flesus. } & \multicolumn{2}{|c|}{ P. microcephalus. } \\
\hline & & & No. & Size & No. & Size. & No. & Size. \\
\hline I. $\mathrm{H}$ & & & 3 & $14 \cdot 5-15$ & - & - & - & - \\
\hline II. $\mathrm{H}$ & 22.v.06 & S. & - & - & 6 & $7-9$ & - & - \\
\hline III. $\mathrm{H}$ & 22.v.06 & M. & 1 & 10 & 7 & $7-9$ & - & - \\
\hline IV. $\mathrm{H}$ & 22.v.06 & B. & 6 & $6-9$ & 16 & $7-8 \cdot 5$ & 6 & 8 \\
\hline V. $\mathrm{H}$ & & B. & 4 & $10-12$ & 6 & $5 \cdot 5-9$ & - & - \\
\hline VI. $\bar{H}$ & 30.v.06 & B. & 26 & $6 \cdot 5-10$ & - & - & - & - \\
\hline VIII. H & & B. & - & - & 24 & $8-11 \cdot 5$ & - & - \\
\hline XI. H & 20.vi.06 & B. & 1 & $13 \cdot 5$ & - & - & - & - \\
\hline XIII. H & , & M. & 6 & $6-10 \cdot 5$ & - & - & - & - \\
\hline XIV. H & & B. & - & - & - & - & 3 & $12-14$ \\
\hline XVII. H & 28.vi.06 & B. & 5 & $7 \cdot 5$ & - & - & 1 & $8 \cdot 5$ \\
\hline XXXI. H & 25.iii.07 & S. & - & - & 7 & $3 \cdot 5-8$ & 1 & 6 \\
\hline XXXII. H & & M. & - & - & 1 & 5 & - & - \\
\hline XXXIII. H & 11.iv. 07 & M. & 8 & $6-7$ & 15 & $4-7$ & - & - \\
\hline XXXIV. H & & B. & 3 & 9 & 20 & $4 \cdot 5-9$ & - & - \\
\hline XXXV. H & 6.vi. 07 & B. & - & - & - & - & 2 & $6-9$ \\
\hline XXXVII. H & , & S. & - & - & - & - & 1 & $10 \cdot 5$ \\
\hline XLII. H & 28.v.08 & ? & 1 & 12 & - & - & - & - \\
\hline XLIV. $\mathrm{H}$ & & ? & 16 & $7 \cdot 5-13$ & - & - & 11 & $9-13$ \\
\hline XLVII. H & 1.vi.08 & B. & 1 & $10 \cdot 4$ & - & - & - & - \\
\hline XLIX. H & , & M. & 2 & $12 \cdot 5-13$ & - & - & - & - \\
\hline L. $\mathrm{H}$ & , & B. & 1 & 13 & - & - & 3 & ca. 8 \\
\hline ? LII. H & 4.vi. 08 & $?$ & - & - & 2 & $8-10$ & - & - \\
\hline LIII. H & , & S. & - & - & - & - & 2 & $7 \cdot 5-11$ \\
\hline LIV. $\mathrm{H}$ & & M. & - & - & 1 & 8 & - & - \\
\hline LV. H & 5.vi. 08 & S. & - & - & - & - & 1 & 7 \\
\hline LVI. $\mathrm{H}$ &, & B. & 1 & 13 & - & - & - & - \\
\hline LX. H & 12.vi.08 & B. & - & - & - & - & 1 & 8 \\
\hline LXVI. H & 19.vi.08 & B. & - & - & - & - & 6 & $7-16$ \\
\hline LXIX. H & 23.vi.08 & S. & - & - & - & - & 1 & 7 \\
\hline LXX. H & , & M. & - & - & - & - & 1 & $8 \cdot 7$ \\
\hline LXXI. H & & B. & - & - & - & - & 2 & $7-8$ \\
\hline LXXIV. H & 30.vi.08 & B. & 1 & 8 & - & - & 5 & $6-8$ \\
\hline LXXV. H & " & B. & - & - & - & - & 9 & $5-8$ \\
\hline XCV. H & 28.iv.09 & S. & - & - & 3 & $7-8$ & - & - \\
\hline XCVI. H & 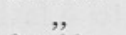 & B. & - & - & 28 & $8-9$ & - & - \\
\hline XCVII. H & 3.v.09 & ? & - & - & 2 & 10 & - & - \\
\hline XCVIII. H & 7.v.09 & $?$ & - & - & 4 & $9-10$ & - & - \\
\hline XCIX. H & 13.v.09 & M. & 12 & $8-12$ & - & - & - & - \\
\hline C. $\mathrm{H}$ & 24.v.09 & S. & - & - & 1 & 8 & - & - \\
\hline CIV. $\mathrm{H}$ & 2.vi.09 & B. & 3 & $8-12$ & - & - & - & - \\
\hline CIX. H & 25.vi.09 & S. & - & - & 1 & 9 & - & - \\
\hline CXVII. H & 13.vii.09 & S. & - & - & - & - & 1 & 7 \\
\hline I. A & 6.vi.13 & S. & - & - & 3 & $7-9 \cdot 31$ & - & - \\
\hline II. A & ", & B. & 2 & 6 & - & - & 2 & $6 \cdot 96-7$ \\
\hline III. A & 11.vi.13 & M. & - & - & 3 & 7 & 9 & - \\
\hline V. A & 12.vi.13 & M. & 1 & $1 \cdot 59$ & - & - & 14 & $7 \cdot 5-11$ \\
\hline VI. A & 13.vi.13 & M. & - & - & - & - & 4 & $7-8 \cdot 5$ \\
\hline IX. A & & B. & - & - & 5 & $7 \cdot 4-8 \cdot 54$ & $4-$ & - \\
\hline X. A & 16.vi.13 & M. & 4 & $7-10 \cdot 15$ & 1 & $8 \cdot 75$ & 3 & $7 \cdot 7-9 \cdot 17$ \\
\hline XIII. A & 18.vi.13 & M. & 2 & $10 \cdot 5-11 \cdot 5$ & - & - & - & - \\
\hline XV. A & ," & M. & 21 & $11 \cdot 06-11 \cdot 34$ & $4-$ & - & 1 & $9 \cdot 5$ \\
\hline XXIII. A & $30 . v i .13$ & B. & 1 & $5 \cdot 39$ & - & - & 1 & 6 \\
\hline XXIV. A & 3.vii.13 & M. & - & - & - & - & 2 & $9 \cdot 5-10$ \\
\hline XXXVII. A & 24.vii.13 & B. & - & - & - & - & 1 & $12 \cdot 5$ \\
\hline XLIII. A & 28.vii. 13 & S. & 3 & $39-42$ & - & - & - & - \\
\hline
\end{tabular}


spawning period for the three species. Kyle has noted an indefinitely prolonged spawning period for $A$. thori and for A. laterna, and has suggested a similar period for $A$. imperialis, although he states that the main spawning period for this last species lies in spring. The occurrence of a large number of larval and early post-larval forms of $A$. imperialis, in August and September, 1913, appears to confirm the view of an extended spawning period.

The frequency of the three species is highest off-shore between the twenty and forty fathom lines, and decidedly low within the twentyfathom line-the captures inside this limit being confined to four specimens, 6 to $16 \mathrm{~mm}$. in length, from hauls $70 \mathrm{~A}$ and $73 \mathrm{~A}$.

It is interesting to note the occurrence in the collection of the pale North Sea and English Channel post-larval form of A. laterna, and the dark Bay of Biscay form of the same species. These two varieties of post-larvæ have been fully described by Kyle, who has suggested a higher number of vertebræ for the more southern form.

\section{Sub-fam. Rномвімж.}

\section{Rhombus maximus Will. R. lavis Rond.}

The few records of these two species indicate an earlier spawning for the brill. Seven of the eight individuals recorded were taken beyond the twenty-fathom line. Permanent bottom stages of the turbot were secured with a push-net in Whitsand Bay on October 1st, 1913. These measured from $25-38 \mathrm{~mm}$. ( $1^{\prime \prime}$ to $\left.1_{2}{ }^{\prime \prime}\right)$ in length, and had fully assumed the adult condition. On the same date, brill of $130-140 \mathrm{~mm}$. (5" to $5 \frac{1{ }^{\prime \prime}}{}$ ) in length were secured in the otter trawl in 3 to 5 fathoms in the same locality. These were probably a little over a year old.

TABLE XV.

Record of Rhombus sp.

\begin{tabular}{|c|c|c|c|c|c|c|c|}
\hline \multirow{2}{*}{$\begin{array}{l}\text { No. of Haul. } \\
\text { XXXIX. }\end{array}$} & \multirow{2}{*}{ A } & \multirow{2}{*}{$\begin{array}{l}\text { Date. } \\
25 \text { vii. } 13\end{array}$} & \multirow{2}{*}{$\begin{array}{l}\text { Depth. } \\
\text { S. }\end{array}$} & \multicolumn{2}{|c|}{ R. maximus. } & \multicolumn{2}{|c|}{ R. lævis. } \\
\hline & & & & No. & Size. & No. & Size. \\
\hline LXXXI. & A & 19.viii.13 & B. & - & - & 1 & $\begin{array}{l}0.20 \\
6.5\end{array}$ \\
\hline CV. & A. & 29.viii.13 & M. & - & - & 1 & $5 \cdot 5$ \\
\hline CXVIII. & A & 5.ix. 13 & M. & - & - & 2 & $3 \cdot 5-4 \cdot 2$ \\
\hline XXXVII. & A & 12.ix. 13 & M. & 1 & 7 & - & - \\
\hline CXL. & A & 15.ix. 13 & M. & 1 & $7 \cdot 3$ & - & - \\
\hline CXLII. & A & 15.ix. 13 & B. & 1 & 7 & - & - \\
\hline
\end{tabular}




\section{Sub-fam. Rhомвinж.}

Scophthalmus norvegicus Gthr. S. unimaculatus Bnp. Zeugopterus punctatus $\mathrm{Bl}$.

\section{Scophthalmus norvegicus Gthr.}

This is the commonest topknot of the district. The records of the pelagic stages in Table 25 indicate an indefinitely prolonged spawning period from March or April to July. The maximum for the post-larvæ lies in June, so that the densest spawning month is most probably May. Frequency is highest between the twenty and thirty fathom lines, and lowest beyond the thirty-fathom line.

\section{TABLE XVI.}

$\begin{array}{lllll}\text { Record of Scophthalmus UnImaculatus } & \text { BNp. } \\ \text { No. of Haul. } & \text { Date. } & \text { Depth. } & \text { No. } & \text { Size. } \\ \text { XI. A } & 16 . v i .13 & \text { B. } & 1 & 7 \cdot 5 \\ \text { XXIII. A } & 30 . v i .13 & \text { B. } & 1 & 7.98 \\ \text { XXXII. A } & 15 . \text { vii.13 } & \text { B. } & 1 & 11\end{array}$

The adult one-spotted topknots are of exceedingly rare occurrence at Plymouth, so that the capture of these three post-larvæ is all the more interesting. They were all secured beyond the twenty-fathom line, from 16th June to 15th July, and were identified with the help of Petersen's descriptions and figures of specimens, ranging from 6.7 to $8 \mathrm{~mm}$. in length.

The oldest stage has a length of $11 \mathrm{~mm}$., and it is still perfectly symmetrical. The concavity of the snout is well marked, and the dorsal fin is almost on a level with the posterior margin of the orbit. The diameter of the eye is contained about three times in the snout length. Ventrals are developed, though still small. The caudal fin is rounded and almost fully developed and about seventeen rays can be counted. The two pairs of otocyst spines are quite conspicuous, though not so prominent as in Z. punctatus.

Small dendritic chromatophores are scattered over the head and body, much as in $S$. norvegicus, though practically absent from the orbital region, and less dense on the interspinous region. There is a suggestion of the pigment on the unpaired fins beginning to concentrate into bars. 


\section{TABLE XVII.}

Record of Zeugopterus punctatus Bloch.

\begin{tabular}{|c|c|c|c|c|}
\hline No. of Haul & Date. & Depth. & No. & Size. \\
\hline IV. $\mathrm{H}$ & 22.v.06 & B. & 1 & 6 \\
\hline V. $\mathrm{H}$ & & B. & 1 & 7 \\
\hline VIII. $\mathrm{H}$ & 30.v.06 & B. & 6 & ca. 11 \\
\hline XIV. H & 20.vi.06 & B. & 1 & 9 \\
\hline XXXIII. H & 11.iv. 07 & M. & 12 & $5-6$ \\
\hline XXXIV. H & & B. & 3 & $3-5$ \\
\hline XXXV. H & 6.vi.07 & B. & 2 & $6-9$ \\
\hline XLIV. $\mathrm{H}$ & 18.v.08 & B. & 2 & $7-7 \cdot 5$ \\
\hline LXVI. H & 19.vi.08 & B. & 1 & 9 \\
\hline XCV. $\mathrm{H}$ & 28.iv.09 & S. & 1 & 4 \\
\hline CIII. $\mathrm{H}$ & 2.vi.09 & M. & 1 & $7 \cdot 5$ \\
\hline CX. H & 10.vi.09 & M. & 1 & 9 \\
\hline I. $\mathrm{A}$ & 6.vi.13 & S. & 10 & $6 \cdot 5-8.5$ \\
\hline III. A & 11.vi.13 & M. & 2 & ca. $5 \cdot 5$ \\
\hline VI. A & 13.vi.13 & M. & 1 & $6 \cdot 3$ \\
\hline XI. A & 16.vi.13 & B. & 1 & $11 \cdot 69$ \\
\hline XV. A & 18.vi.13 & M. & 2 & $8-8 \cdot 5$ \\
\hline
\end{tabular}

Zeugopterus punctatus $\mathrm{Bl}$.

Post-larvæ occurred from April to June, with their maximum in June. The spawning period probably extends from March to May for the Plymouth area. Hefford gives middle of February to May. Their distribution is general, though there is a much higher frequency under ten fathoms and between the twenty and thirty fathom lines.

Sub-fam. SoLEINæ.

\section{TABLE XVIII.}

\section{Record of Solea.}

\begin{tabular}{|c|c|c|c|c|c|c|c|c|c|}
\hline \multirow[b]{2}{*}{ No. of Haul. } & \multirow[b]{2}{*}{ Date. } & \multirow[b]{2}{*}{ Depth. } & & \multicolumn{2}{|c|}{ S yamegnta } & \multicolumn{2}{|c|}{ S. lutea. } & \\
\hline & & & No. & $\begin{array}{l}\text { Size. } \\
\text { mm. }\end{array}$ & No. & $\begin{array}{l}\text { Size. } \\
\text { mm. }\end{array}$ & No. & $\begin{array}{l}\text { Size. } \\
\text { mm. }\end{array}$ & $\begin{array}{l}\text { Size. } \\
\text { Hm. }\end{array}$ \\
\hline I. $\mathrm{H}$ & $0 \times 06$ & B. & 1 & $10 \cdot 5$ & $n e+9$ & - & - & - & - \\
\hline IV. $\mathrm{H}$ & & & 2 & 4 & 72 & 6 & - & - & - \\
\hline VI. $\mathrm{H}$ & & & - & - & 6 & 6 & - & - & - \\
\hline VIII. H & & & 1 & 9 & - & - & - & - & - \\
\hline XIII. $\mathrm{H}$ & 0.vi.06 & & - & - & 2 & $4 \cdot 2$ & - & - & \\
\hline . I & & & - & - & 1 & 6 & - & - & - \\
\hline [. 1 & & & - & - & 5 & $4-8$ & - & - & - \\
\hline . I & & & - & - & 1 & & 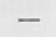 & - & \\
\hline $\mathrm{T}$ & & & - & - & 2 & & - & - & - \\
\hline LV & & & - & - & 3 & & - & - & - \\
\hline & & & - & - & & & - & - & \\
\hline $\mathrm{x} . \mathrm{H}$ & & & - & - & & & - & - & \\
\hline [. & & & - & - & 2 & & - & - & - \\
\hline & & & 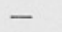 & - & 14 & & - & - & - \\
\hline . & & & - & - & 5 & $7-8$ & - & - & - \\
\hline . & & & - & - & 1 & & - & - & - \\
\hline & 23.vi.08 & & - & - & & & - & 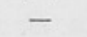 & \\
\hline & & & - & - & 49 & $4 \cdot 5$ & - & - & - \\
\hline . 1 & & & - & - & 8 & & - & $-5+2-1$ & - \\
\hline it & vii. & & - & - & - & - & 1 & 4 & - \\
\hline 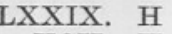 & & B & - & - & 1 & 1 & 3 & $4 \cdot 8-6$ & \\
\hline 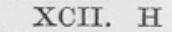 & & B & - & - & - & - & 1 & 6 & - \\
\hline CV & v. 0 & & & 2 & - & - & - & - & - \\
\hline
\end{tabular}


TABLE XVIII.-Continued.

ReCord of Solea.

\begin{tabular}{|c|c|c|c|c|c|c|c|c|c|c|}
\hline \multirow{2}{*}{\multicolumn{2}{|c|}{ No. of Haul. }} & \multirow[b]{2}{*}{ Date. } & \multirow[b]{2}{*}{ Depth. } & \multicolumn{2}{|r|}{ ris. } & & \multicolumn{2}{|c|}{ s. lutea. } & $\begin{array}{l}\text { S. lascaris. } \\
\text { No Size }\end{array}$ \\
\hline & & & & & $\begin{array}{l}\text { Size. } \\
\mathrm{mm} \text {. }\end{array}$ & & $\begin{array}{l}\text { Size } \\
\mathrm{mm} \text {. }\end{array}$ & & $\begin{array}{l}\text { Size. } \\
\text { mm. }\end{array}$ & $\begin{array}{ll}\text { No. Size, } & \text { mm. }\end{array}$ \\
\hline CI. & $\mathrm{H}$ & 24.v.09 & & 1 & & - & & - & & \\
\hline CIII. & $\mathrm{H}$ & 2.vi.09 & M. & 1 & 5 & - & - & - & - & - \\
\hline $\begin{array}{l}\text { CIV. } \\
\text { CXVII. }\end{array}$ & $\mathrm{H}$ & & B. & 1 & 6 & - & - & - & - & - \\
\hline $\begin{array}{l}\text { CXVII. } \\
\text { CXXII. }\end{array}$ & $\mathrm{H}$ & 13.vii.09 & S. & - & - & 1 & $4 \cdot 5$ & - & - & - \\
\hline $\begin{array}{l}\text { CXXII. } \\
\text { CXXIV. }\end{array}$ & $\mathrm{H}$ & 20.vii.09 & B. & - & - & 2 & $5 \cdot 3-10$ & - & - & - \\
\hline $\begin{array}{l}\text { CXXIV. } \\
\text { CXXV. }\end{array}$ & $\mathrm{H}$ & 6.viii.09 & M. & - & - & 1 & 5 & - & - & - \\
\hline $\begin{array}{l}\text { CXXV. } \\
\text { CXXXI. }\end{array}$ & $\mathrm{H}$ & & B. & - & - & 2 & $6-7$ & - & - & - \\
\hline CXXXI. & $\mathrm{H}$ & 27.viii.09 & M. & - & - & 2 & ca. 4 & - & $=$ & - \\
\hline $\begin{array}{l}\text { I. } \\
\text { II. }\end{array}$ & A & 6.vi.13 & S. & - & - & - & - & 1 & $\begin{array}{l}4.55 \\
3.7 .8\end{array}$ & $\overline{-}$ \\
\hline $\begin{array}{l}\text { III. } \\
\text { III. }\end{array}$ & A & & B. & 1 & $6 \cdot 86$ & $\overline{24}$ & - & 3 & $3 \cdot 7-5 \cdot 8$ & - \\
\hline $\begin{array}{l}\text { III. } \\
\text { V. }\end{array}$ & A & 11.vi.13 & M. & - & - & 24 & $3 \cdot 9-6 \cdot 5$ & - & - & - \\
\hline $\begin{array}{l}\text { V. } \\
\text { VI. }\end{array}$ & A & 12.vi.13 & M. & - & - & 2 & $5 \cdot 1-6 \cdot 1$ & 2 & $3 \cdot 85-4 \cdot 9$ & - \\
\hline $\begin{array}{l}\text { VI. } \\
\text { XII. }\end{array}$ & A & 13.vi.13 & M. & 1 & $8 \cdot 75$ & - & - & 1 & 6.51 & - \\
\hline $\begin{array}{l}\text { XII. } \\
\text { XIV. }\end{array}$ & A & 18.vi.13 & S. & - & - & 1 & 8 & - & - & - \\
\hline XIV. & A & ," & B. & - & - & 2 & $6 \cdot 95-11$ & - & - & - \\
\hline XV. & A & & M. & - & - & 1 & $7 \cdot 49$ & - & - & - \\
\hline $\begin{array}{l}\text { XVI. } \\
\text { XVII. }\end{array}$ & A & 19.vi.13 & M. & - & - & - & - & 2 & $5-7 \cdot 35$ & - \\
\hline XVII. & A & & M. & - & - & - & - & 2 & $4 \cdot 2$ & - \\
\hline $\mathrm{xx}$. & A & 20.vi.13 & $\mathrm{S}$ & - & - & 3 & $5-6 \cdot 3$ & - & - & - \\
\hline XXII. & A & $27 . \mathrm{vi}$ & M. & - & - & 4 & $4 \cdot 13-7$ & 1 & $4 \cdot 5$ & - \\
\hline XXIII. & A & 3 & B. & - & - & 3 & $5 \cdot 25-7$ & - & - & - \\
\hline XXXIX. & A & 25.vii.13 & S. & - & - & - & - & - & - & $1 \quad 5.025$ \\
\hline XCVI. & A & 25.viii.13 & B. & - & - & 2 & $8-8.5$ & - & - & - \\
\hline XCVIII. & A & & M. & - & - & - & - & - & - & $\begin{array}{ll}3 & 6-9 \cdot 5\end{array}$ \\
\hline c. & A & 27.viii.13 & M. & - & - & - & - & - & - & 8 \\
\hline CII. & A & & M. & - & - & - & - & - & - & 10.5 \\
\hline CIV. & A & 29.viii.13 & I & - & - & - & - & - & - & 1 damagec \\
\hline CX. & A & 1.ix & B. & - & - & - & - & - & - & 8.5 \\
\hline CXX. & A & 8.ix.13 & M. & - & - & - & - & - & - & 1 \\
\hline CXXIII. & A & & M. & - & - & - & - & - & - & $4 \cdot 5$ \\
\hline CXXV. & A & 9.ix.13 & & - & - & - & - & - & - & 11 \\
\hline CXXX. & A & 10.ix.13 & M. & - & - & - & - & - & - & $4 \cdot 69$ \\
\hline CLV. & A & $20 . i x .13$ & B. & - & - & - & - & - & - & $7 \cdot 5$ \\
\hline CLIX. & A & 22.ix.13 & B. & - & - & - & - & - & - & $1 \quad 11.25$ \\
\hline CLXI. & A & & M. & - & - & - & - & - & - & \\
\hline CLXIII. & A & 24.ix.1 & M. & - & - & - & - & - & - & $27-10.5$ \\
\hline CLXIX. & A & & M. & - & - & - & - & - & - & $1 \quad 5.5$ \\
\hline CLXXI. & A & $26 . \mathrm{ix} .13$ & M. & - & - & - & - & - & - & $1 \quad 5 \cdot 786$ \\
\hline CLXXII. & A & 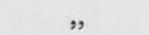 & M. & - & - & - & - & - & - & $7 \cdot 75$ \\
\hline CLXXIII. & A & & B. & - & - & - & - & - & - & 11.5 \\
\hline CLXXXII. & A & 30.ix.13 & M. & - & - & - & - & - & - & $37.5-11.5$ \\
\hline
\end{tabular}

Solea vulgaris Quensel. S. variegata Don. S. lutea Risso.

S. lascaris Risso.

Four species of soles are found in the neighbourhood, and all are represented in the post-larval material from the early post-larva up to the metamorphosing stage.

These are : S. vulgaris Quens. Common sole.

S. variegata Don. Thickback.

S. lutea Risso. Solenette.

S. lascaris Risso. Sand-sole.

With a post-larval series of each, specific determination has been 
comparatively easy. Of the four species, S. variegata (thickback) occurs most frequently. The maximum number of post-larvæ was in June. They were taken in diminishing numbers on to August. This coincides with the period recorded by Petersen for the capture of his post-larval specimens-May to July. Records of S. lutea are confined to July and August, but the number of individuals is extremely small. S. lascaris occurred in increasing numbers from July to September, after which month they disappeared from the pelagic hauls. S. vulgaris post-larvæ were taken in May and June, but were extremely few, and by no means representative of the number of individuals in the neighbourhood. S. vulgaris and S. lutea show a higher frequency inshore at depths of about ten fathoms or less, while $S$. variegata and $S$. lascaris have a distinctly low frequency for this area. The maximum for these two species lies between the twenty and thirty fathom lines. Both were taken beyond the thirty-fathom line, and it is possible, at least for $S$. variegata, that the frequency may increase with the distance from land. Our knowledge of the life-history and developmental stages of S. vulgaris and S. lutea is fairly complete. Kyle has remarked on the greater breadth of similar forms of $S$. lutea from the more southern waters to those from the North Sea. My specimens of $S$. lutea show a distinct gradation from the one to the other. The greatest breadth (without the dorsal fin) ranges from about $25 \%$ to slightly over $40 \%$ of the total length.

\section{S. variegata Don.}

Post-larval S. variegata are known chiefly from the researches of Petersen,* whose specimens were captured mostly over depths from 1000 to 4000 metres, though he recorded captures from 53 and 113 metres. The series ranged from 7 to $18.3 \mathrm{~mm}$. in length. At the latter length, metamorphosis was a long way off completion. It seems peculiar that my specimens are equally well advanced in development, but at a much smaller size. My post-larvæ of almost $4 \mathrm{~mm}$. are closely identical with Petersen's $7 \mathrm{~mm}$. post-larva, and just as far advanced in development. At $11 \mathrm{~mm}$. in my material metamorphosis has already reached almost half-way. There is at a length of $11 \mathrm{~mm}$., the largest post-larva in my collection, a distinctive difference in pigmentation from Petersen's metamorphosed specimen. The pigment is not confined to the fins, interspines, and margin of the abdomen and head, but also scattered universally over the whole of the body, not as tiny black dots, but as fairly stout stellate chromatophores of moderate size.

* Medd. fra Komm. f. Havund. Serie Fisk. Bind III, Nr. 1. 1909. 
As Kyle* has remarked on his single specimen of $7 \mathrm{~mm}$., the depth of body is considerable. This is also a characteristic feature in nearly all my specimens, and contrasts with the much narrower body of Petersen's post-larvæ. There is the further difference to be considered in the localities of the two captures. The area of maximum intensity of this species in the region investigated at Plymouth lies between the twenty and thirty fathom lines, at no great distance from land, whereas Petersen secured his specimens at considerable distances offshore, and over much greater depths.

The numerical characters of my specimens certainly agree with those of S. variegata. D 71-72,

\section{A $56-57$,}

Vertebræ $9(10)+29(30)(31)$.

Petersen gave for his post-larvæ D 71-76,

$$
\begin{aligned}
& \text { A 46-60 } \\
& \text { Vertebræ } 9(10)+29(30)(31)(32) .
\end{aligned}
$$

Kyle's single specimen of $7 \mathrm{~mm}$. had $10+30$ vertebræ.

Structural and post-larval characteristics are much the same in my specimens as in Petersen's, except for those few characters noted above. There is no trace of an air bladder nor of barred pigment. Holt and Byrne have noted this barred pigmentation for the transition stage, and Mr. Byrne has kindly supplied me with a note on a specimen $16 \mathrm{~mm}$. long (without caudal) having the general appearance of the adult. It was taken 50 miles W.N.W. of Cleggan Head, at a depth of about 120 fathoms. The youngest specimen with the adult appearance which I have observed at Plymouth measured $45 \mathrm{~mm}$. Further investigation is required, especially in the later metamorphosing stages, to arrive at a fuller knowledge of this species.

\section{S. lascaris Risso. (Sand-sole.)}

Our knowledge of the post-larval development of the sand-sole is extremely limited. It is confined practically to two specimens, one of $8 \mathrm{~mm}$., described by Kyle in "Rep. of the Danish Oceanographical Expeditions, 1908-10, No.2"; the other of $11 \mathrm{~mm}$., described by Cunningham as a metamorphosing stage of S. vulgaris or S. lascaris in Journal M.B.A., 1897-99. Ehrenbaum was the first to attribute this latter specimen definitely to $S$. lascaris, and, from the material at my disposal, there is no doubt about his identification being correct.

* Report Dan. Ocean. Exped., 1908-10. No. 2. 1913. 
Several adult $S$. lascaris have been trawled from time to time, principally in Whitsand Bay, and I have thought it worth while to give a record of their numerical characters. Nine of these specimens were cut up and the vertebræ counted. In the other eleven individuals the fin formula alone has been recorded.

\begin{tabular}{cccc}
\multicolumn{5}{c}{ NUMERICAL CHARACTERS } & OF & ADULTS. \\
1 & 80 & 65 & 46 \\
2 & 90 & 76 & 48 \\
3 & 85 & 70 & 46 \\
4 & 87 & 69 & 46 \\
5 & 87 & 71 & 47 \\
6 & 86 & 70 & 46 \\
7 & 81 & 66 & 47 \\
8 & 83 & 67 & 48 \\
9 & 88 & 72 & 46 \\
10 & 80 & 67 & - \\
11 & 86 & 70 & - \\
12 & 86 & 69 & - \\
13 & 91 & 73 & - \\
14 & 84 & 69 & - \\
15 & 82 & 71 & - \\
16 & 85 & 69 & - \\
17 & 85 & 71 & - \\
18 & 87 & 73 & - \\
19 & 91 & 73 & - \\
20 & 82 & 68 & -
\end{tabular}

Summary for 20 specimens :-

$\begin{array}{llll} & \text { D } 80-91 & \text { A } 65-76 & \text { Vertebræ 46-48 } \\ \text { Kyle gives } & \text { D 79-89 } & \text { A 61-70 } & \text { Vertebræ 47-48 }\end{array}$

My post-larvæ give the following range :-
D $89-96$
A 68-76
Vertebræ ca. 47

There is thus an extension to Kyle's summary, which works out as follows :-

$$
\begin{aligned}
& \text { D } 79-96 \\
& \text { A } 61-76 \\
& \text { Vertebræ } 46-48
\end{aligned}
$$

This large amount of variation seems to be a characteristic feature in the genus Solea.

From previous records of the eggs of this species, and from the occurrence of the post-larval forms, spawning seems to take place during June, July, and August. Hefford recorded the capture of one egg in March, the resulting larva of which he described and figured.* Holt $\dagger$

* Journ. M.B.A. Vol. IX. 1910.

† Sci. Trans. Roy. Soc. Dublin. Vol. IV, S. 2. 1891. 
obtained the newly hatched larva at a length of $4.1 \mathrm{~mm}$., but its appearance was entirely different from Hefford's specimen. The distinguishing feature was a well-marked pre-cephalic expansion of the dorsal fin membrane. It was taken much later in the year, and thus more in agreement with the known spawning period than Hefford's larva. My earliest postlarvæ have all got this peculiar "hooded" structure, though much less pronounced. There is distinct evidence in my specimens of shrinkage in this region, so that there seems to be grounds for believing that this pre-cephalic structure was indeed larger in the larval state. I am inclined to consider Hefford's larva, though not without great reservation, as belonging to another species, possibly S. variegata. The pigmentation, shape of head, depth of body, more backward position of the anus, and length of the specimen seem to agree more nearly with the characters of $S$. variegata. I have described and figured post-larval stages from 5.025 to $11.25 \mathrm{~mm}$. The rate of growth seems rather unequal, and considerable variation is apparent. The metamorphosed specimen of $11.25 \mathrm{~mm}$., though far from having completed its post-larval growth, represents perhaps the minimum length for such an advanced stage, as in specimens of $11.5 \mathrm{~mm}$., the left eye has not even reached the dorsal margin.

\section{S. lascaris Risso.}

\section{Fig. 5. Length 5.025 mm.}

Length $5.025 \mathrm{~mm}$., of which $3.4 \mathrm{~mm}$. are post-anal. The preanal length is about $2 \frac{1}{2}$ times in the total, so that the anus is well in front of the middle of the body. The snout is slightly longer than the diameter of the eye. The lower jaw projects beyond the upper. The greatest depth, which is measured over the middle of the abdominal region, is slightly under three times in the total length. The development of the fin rays is suggested posteriorly by the arrangement of the dorsal and anal pigment. Hypural rays are developed. The vertebræ have not advanced sufficiently to be counted. The snout is compressed and notched where it receives the dorsal fin membrane. The membrane curves back half-way over the nasal region and parallel to it, and then rises almost vertically, giving the larva a " hooded" appearance. This feature is quite distinctive of S. lascaris, and reminds one of Holt's newly hatched $(4 \cdot 1 \mathrm{~mm}$.) larva of the same species with its "abnormal" development of this region. The midbrain is prominent; it overlies the orbit and its anterior outline is almost parallel to the anterior dorsal fin margin. The eyes are perfectly sym- 
metrical. There is a distinct suggestion of an air bladder in a curved line of dark pigment lying on the middle of the dorsal margin of the abdominal region. As yet, there is no appearance of interspines. The notochord is straight or nearly so. The pectorals are fairly large, and equally developed.

The pigmentation is striking, and quite distinctive. The head, body, and abdomen are covered with large, exceedingly delicate stellate chromatophores, which assume a faint bronze tint in formalin. These are largest on the abdominal region. A few dark stellate chromatophores are present on the dorsal surface of the brain region. On the dorsal fin membrane, and similarly on the anal, there is a large aggregation of these chromatophores posteriorly, which assume a pronounced bar formation. On the dorsal fin also are two large much darker chromatophores, which stand out clearly from the rest of the pigment-one is situated

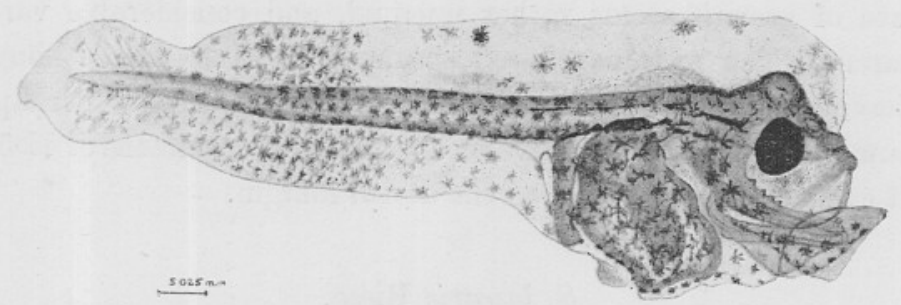

FIG. 5.-- Solea lascaris. Length $5.025 \mathrm{~mm}$. Oithona Station, XXXIX. A. 25th July, 1913. Total depth 25 fms. Surface haul.

Del. E. Ford.

over the beginning of the notochord, the other about half-way along the fin. A few delicate chromatophores are present on the anterior expansion of the dorsal fin membrane, and near the large mid-dorsal chromatophore. The caudal is sparsely pigmented. Several chromatophores are scattered over the anal fin in front of the posterior bar, while a row of small dark chromatophores extends along the margin of the abdomen to the tip of the snout. The dark curve of the air bladder has already been mentioned. There are extensions in front towards the eye, and behind as far as the downward curve of the intestine. An interrupted line of pigment runs from behind the eye, on a level with its dorsal margin, for a considerable distance along the notochord.

\section{Fig. 6. Length $6 \mathrm{~mm}$.}

The preanal length is considerably less than half the total length. The snout is slightly larger than the diameter of the eye. The fin formula cannot be counted, at least dorsally, though the anal fin rays are much 
farther advanced. The vertebræ number about $9+38=47$. The lower jaw still projects. The snout is decidedly more vertical and almost continuous in outline with the dorsal fin margin, except for a small indentation marking the origin of the dorsal fin. The dorsal fin protuberance is almost parallel with the margin of the mid brain, the anterior border of which is in advance of the orbit. The eyes are symmetrical. Interspines have developed. The first dorsal interspine lies directly over the middle of the medullary region. The air bladder is now well defined and is comparatively large-its length being almost equal to that of the snout. The notochord is still straight.

The pigment is much more pronounced, though similar in arrangement

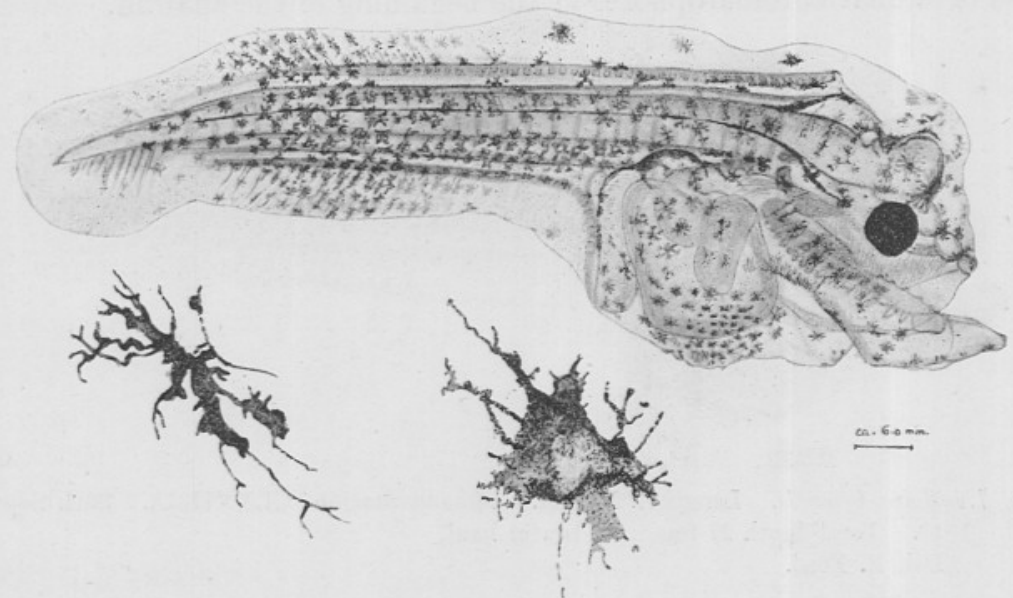

Fig. 6.-Solea lascaris. Length ea. $6 \mathrm{~mm}$. Oithona Station, XCVIII. A. 25th Aug., 1913. Total depth $36 \mathrm{fms}$. Midwater haul.

Fic. 6a.-Chromatophores enlarged.

Del. E Ford.

to that in the previous specimen. Chromatophores are developed on the snout and on the brain region, which latter is distinctly marked by a line of dark pigment, stretching from the fore brain, over the mid brain, hind brain and medulla, and ending with the beginning of the notochord. The notochordal line of pigment is less interrupted, and reaches almost to the caudal. This line of pigment marks out the ventral aspect of the spinal chord. An interrupted line of pigment runs along the base of the anal interspines, becoming more distinct in the region of the posterior bar of pigment.

Fig. 7. Length $7 \cdot 75 \mathrm{~mm}$.

The preanal length is $3.42 \mathrm{~mm}$. The snout (measured from the tip of the upper jaw to the anterior margin of the eye) is about equal to the 
diameter of the eye. The dorsal and anal fin rays have advanced considerably and stretch half-way across the fin membranes, though not sufficiently clear on the distal portions of the fins to be counted with accuracy. Vertebræ number approximately $9+37$. The notch in front of the origin of the dorsal fin is much more conspicuous. It overlies the region of the mid brain. The interspines have extended forwards. The tip of the notochord is bent upwards, and the caudal rays are developed : twelve rays can be counted.

A few stellate chromatophores have collected round the two large separate dorsal fin chromatophores at positions corresponding to the future pigment bars. The first anal bar is also suggested by an aggregation of similar chromatophores at the beginning of the anal fin.

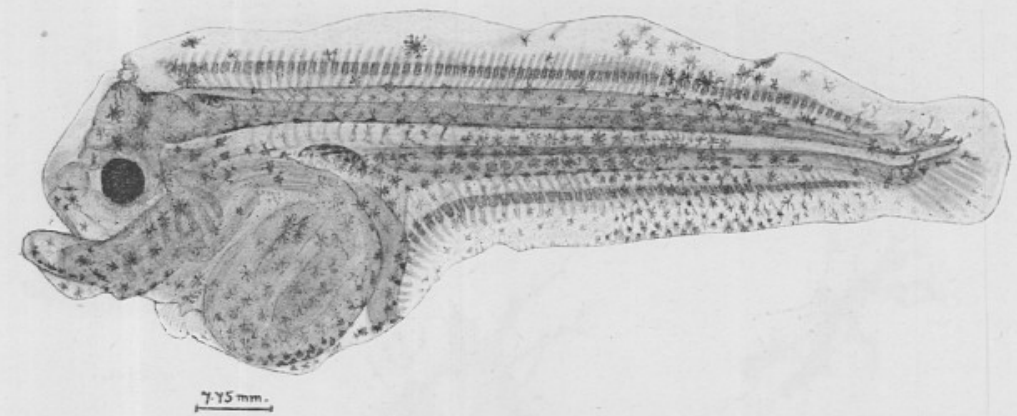

FIG. 7.-Solea lascaris. Length $7 \cdot 75 \mathrm{~mm}$. Oithona Station, CLXXII. A. 26th Sept., 1913. Total depth 27 fms. Midwater haul.

Del, E. Ford.

Fig. 8. Length $8.7 \mathrm{~mm}$.

Length $8.7 \mathrm{~mm}$., of which $5.69 \mathrm{~mm}$. are post-anal. The anus is thus well in front of the middle line. Length of snout ca. $.5 \mathrm{~mm}$. (measured from tip of upper jaw); diameter of eye ca. $4 \mathrm{~mm}$. The greatest depth is slightly more than the preanal length. Length of air bladder about equal to snout length.

Fin formula D ca. 89.

A ca. 73 .

Vertebræ $9+$ ca. $38=$ ca. 47 .

The snout is more rounded and swollen anteriorly, and extends backwards to the origin of the dorsal fin membrane, which projects as a small knob in front and above the mid brain, the anterior margin of which is in line with that of the orbit. The dorsal interspines have advanced to a level with a vertical line through the middle of 
the eye, and are well developed. The lower jaw still projects a little, and the mouth has a downward curve. The eyes are symmetrical. The tip of the notochord is bent upwards, and the caudal rays are almost fully developed.

The general appearance of pigment is very much the same as in the last specimen. There are now three distinct barred regions in the dorsal fin and two in the anal. The median dorsal bar lies exactly opposite the anterior anal bar, while the posterior dorsal bar seems to be continued across the body on to the anal fin. The two large separate dorsal fin chromatophores have disappeared, and their place is occupied with the median and anterior aggregates of chromatophores. Distinct dashes

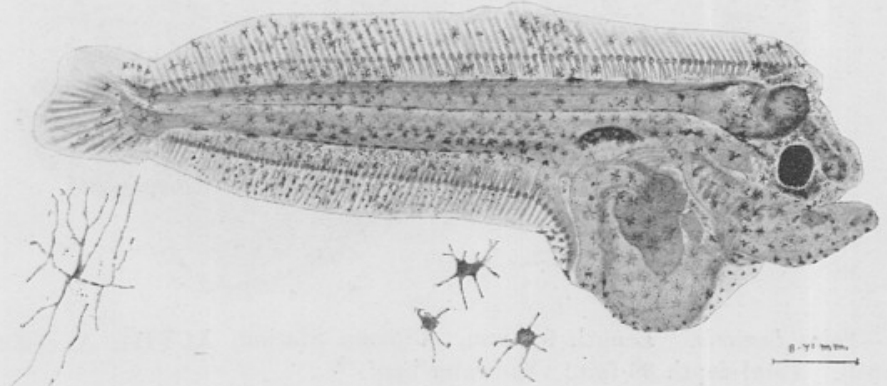

Fig. 8.-Solea lascaris. Length $8.7 \mathrm{~mm}$. Oithona Station, CXX. A. 8th Sept., 1913. Total depth $25 \mathrm{fms}$. Midwater haul.

Fig. 8a.-Chromatophores enlarged.

Del. E. Ford.

of black pigment are present along the bases of the interspines dorsoventrally, but fewer in number and of larger size dorsally. Black dots occur on the chin, along the abdominal margin and on the anal fin, but these are obviously the centres of extremely delicate stellate chromatophores. The caudal fin is weakly pigmented-a few chromatophores occurring near the base and along the lower rays. The specimen is equally pigmented on both sides.

Fig. 9. Length $9.5 \mathrm{~mm}$.

The snout is larger than the diameter of the eye by about $\frac{1}{5}$. The greatest depth is slightly more than the preanal length.

$$
\begin{array}{ll}
\text { Fin formula } & \text { D ca. } 89 . \\
& \text { A ca. } 71 . \\
\text { Vertebræ } & 9+\text { ca. } 38=\text { ca. } 47 .
\end{array}
$$

The concavity of the snout and dorsal fin membrane is clearly Vshaped. The mid brain has receded and on a level with the last third of the orbit. The eyes are still symmetrical. The lower jaw is practically 
on a level with the upper, but the chin projects, while the curve of the mouth is even more pronounced than in the previous specimen. The dorsal interspines have reached beyond the mid brain, and in line with a vertical through the middle of the orbit.

The pigment is much as in the previous specimen, with the barred areas forming a distinct feature. The spinal chord is marked out above and below by a continuous row of small dashes, while across the base of the caudal fin the chromatophores appear to be arranged into another small transverse bar.

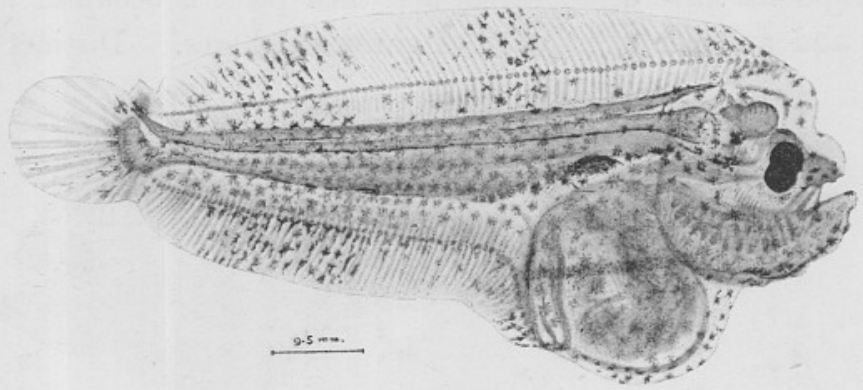

FIG. 9.-Solea lascaris. Length $9.5 \mathrm{~mm}$. Oithona Station, XCVIII. A. 25th Aug., 1913. Total depth 36 fms. Midwater haul.

Del. E. Ford.

Length $10.0 \mathrm{~mm}$. The preanal and post-anal lengths show the same proportion as in the previous specimens. The snout is also longer than the diameter of the eye.

$$
\begin{array}{ll}
\text { Fin formula } & \text { D } 89 . \\
& \text { A } 71 . \\
\text { Vertebræ } & 9+38=47 .
\end{array}
$$

The concavity of the snout is still well marked, though not quite so markedly V-shaped. The left eye has begun to migrate. The interspines have advanced beyond the vertical from the anterior margin of the left orbit, which is slightly in front of the right. The brain has receded, and the anterior margin of the mid brain overlies the middle of the right eye.

There is practically no difference in pigmentation from the last specimen.

\section{Fig. 10. Length $11 \mathrm{~mm}$.}

Metamorphosis has gone a stage farther. The left eye is almost clear of the right, but has not yet reached the dorsal surface. The snout is more or less "hooked," with the lower arm of the V-shaped concavity 
almost horizontal, round which the left eye will undoubtedly travel. The abdomen is beginning to get enclosed.

Fin formula D 89.

A ca. 68 .

Vertebræ $\quad 9+38=47$.

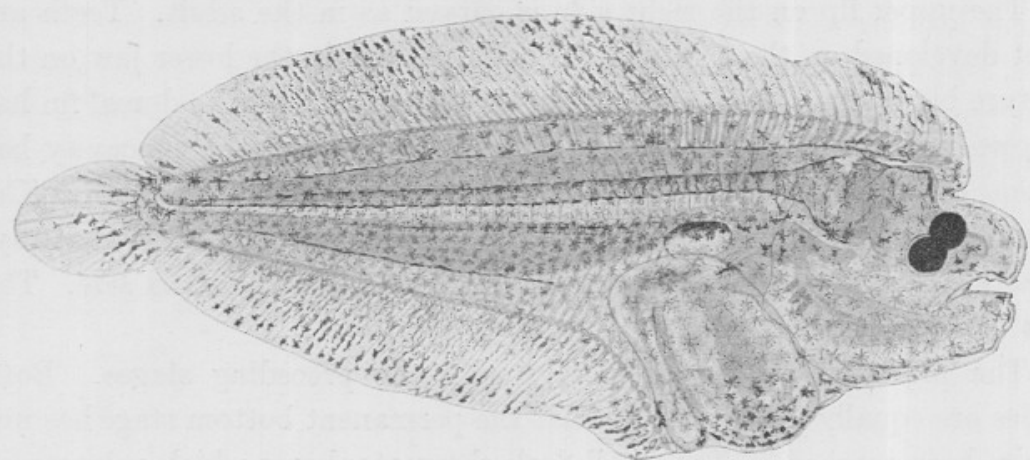

Fig. 10.-Solea lascaris. Length $11 \mathrm{~mm}$. Oithona Station, CXXV. A. 9th Sept., 1913. Total depth $25 \mathrm{fms}$. Midwater haul.

Del. E. Ford.

Large exceedingly delicate stellate chromatophores are diffusely scattered over the head, body, and abdomen. The dorsal and anal fins retain the darker barred aggregates, while a similar bar is present on

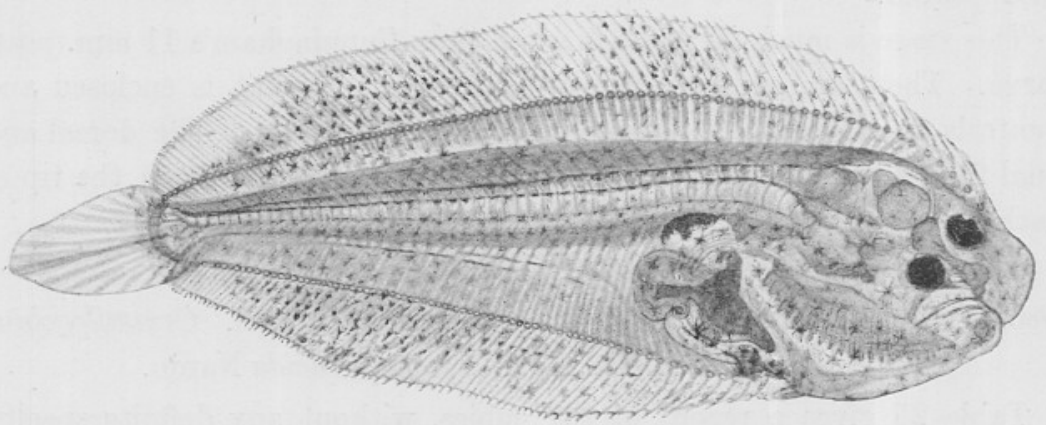

FIG. 11.-Solea lascaris. Length $11.25 \mathrm{~mm}$. Oithona Station, CLIX. A. 22nd Sept., 1913. Total depth $27 \mathrm{fms}$. Bottom haul,

Del. E. Ford.

the base of the caudal fin, the posterior half of which is devoid of pigment.

\section{Fig. 11. Length $11.25 \mathrm{~mm}$.}

Length $11.25 \mathrm{~mm}$., of which $8.5 \mathrm{~mm}$. are post-anal. The preanal length has considerably lessened. The left eye is almost wholly in NEW SERIES,-VOL, $x$. No. 2 . JUNE, 1914. 
advance of the right, which is contained about twice in the snout length (reckoned from tip of snout to margin of right eye).

Fin formula D ca. 96 .

A ca. 76 .

Vertebræ $\quad 9+37(38)=46(47)$.

The upper lip on the right side is curved as in the adult. Teeth are not developed on the right side, though present in the lower jaw on the future blind side. Both eyes are on the right side, and the dorsal fin has grown forward on to the middle of the snout so that the concavity has been overgrown. The abdominal region is entirely enclosed. The ventrals are equally developed, and reach almost to the first anal ray. There is still no trace of the large fringed nostril on the blind side. The air bladder is rather large.

The pigmentation agrees closely with the preceding stages. Both sides are equally pigmented, so that the permanent bottom stage has not quite been reached. The small dark chromatophores which are present on the abdominal margin of the previous stages have now collected into a dense aggregate over the anus. Stellate chromatophores are universally distributed, and extremely delicate, having a rusty-brown appearance. The three dorsal and two anal bars are still quite distinct, while the smaller bar across the base of the caudal has practically disappeared.

This stage is much farther advanced than Cunningham's $11 \mathrm{~mm}$. postlarva. There are six more dorsal rays; the abdomen is enclosed and ventrals are developed. The rough saw-like margins of the dorsal and anal fins are quite typical, and the rays in my specimen reach the tip of each tooth.

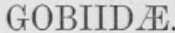

Gobius minutus Pall. G. microps Kr. G. scorpioides Coll. Crystallogobius nilssoni Düb. and Kör. Aphya pellucida Nardo.

Table 25 gives a record of the gobies, without any definite specific arrangement. These are chiefly G. minutus, though G. microps, which appears to be quite a distinct form, is also well represented.

\section{G. scorpioides Collett.}

One specimen, $11 \mathrm{~mm}$. in length, was taken in a midwater haul (192 A) on 24th October, 1913, 6 miles west of Rame Head, over a depth of 26 fathoms. Previous records of this small goby have been remarkably few, and, as Holt and Byrne have remarked, there is little chance of its being taken unless by special methods. Two adult specimens were 
taken by Crawshay* in the outer western area of the English Channel, 31 and $33 \mathrm{~mm}$. in length, at a depth of about 50 fathoms.

The pigmentation of the single specimen recorded differs considerably from that of the full-grown adult. Two conspicuous pale bands are represented. One lies across the caudal peduncle, as in the adult; the other occupies a position directly behind the head in the region of the pectoral and first dorsal fins. A faint yellow tinge is present on the caudal and pectoral fins, while alternate dark and light bands are present on the dorsal fins. Pigment is very sparing on the ventrals, being limited to a few dark splashes at the base and on the middle of the larger rays.

\section{Crystallogobius nitssoni Düb. and Kören.}

Adult Crystallogobius are frequently met with in the neighbourhood, being especially numerous on the Eddystone Grounds. Sexual dimorphism is a distinct characteristic. The males have considerably more pigment than the females, while the body is deeper and more compressed laterally than in the female, which has a much more slender body and more pointed head. The first dorsal fin is present only in the male, and contains two long rays. The second ray is the longer, and is joined to the body by a wide membrane.

In June, adult males were found in attendance on the eggs, which were attached to the inside of empty tubes of Chatopterus variopedatus. These were trawled on the Eddystone Grounds, chiefly in the area south and west of the Eddystone rocks. A similar habitat was noted by Grieg, $\uparrow$ who observed the eggs of this species inside tubes of $C$. sarsi.

The records of this species confirm Holt's observations on the pelagic habit of this transparent goby. The young stages have not been sufficiently cleared up to give a definite idea of the distribution and lifehistory of the species.

TABLE XIX.

\begin{tabular}{|c|c|c|c|c|}
\hline CR & US & $\mathrm{N}$ & $\mathrm{B}$ & ND \\
\hline $\begin{array}{l}\text { No. of Haul. } \\
\text { VII. H }\end{array}$ & $\begin{array}{c}\text { Date. } \\
\text { 30.v.06 }\end{array}$ & $\begin{array}{l}\text { Depth. } \\
\text { S. }\end{array}$ & No. & $\begin{array}{l}\text { Size. } \\
24 \cdot 30\end{array}$ \\
\hline XI. H & 20.vi. 06 & B. & 86 & $21 \cdot 5-36.5$ \\
\hline XXVIII. H & 21.ix.06 & B. & 1 & 22 \\
\hline LXI. H & 15.vi.08 & B. & 6 & $22-36$ \\
\hline CXXIV. H & 6.viii.09 & M. & 1 & 29 \\
\hline CXXV. H & & B. & 3 & $29-30$ \\
\hline XI. A & 16.vi.13 & B. & 1 & 24 \\
\hline XIII. A & 18.vi.13 & M. & 31 & $23-28$ \\
\hline XIV. A & & B. & 14 & $20-30 \cdot 5$ \\
\hline CXIII. A & 3.ix.13 & S. & 1 & 28 \\
\hline CXCII. A & $24 . x .13$ & M. & 102 & $14-26 \cdot 5$ \\
\hline CXCIII. A & , & B. & 93 & $14-21 \cdot 5$ \\
\hline CXCIV. A & $"$, & M. & 17 & $13-25$ \\
\hline
\end{tabular}

* Journ. M.B.A. N.S., Vol. IX. 1910-13. † Bergens Museums Aarbog. 1898. 


\section{GOBIID $\nexists$.}

\section{Aphya pellucida Nardo.}

The post-larval stages of this species are very much like those of Crystallogobius, from which they have been separated with difficulty. The fin formula has been counted in most of the specimens, and has given D 11-12, A 11-12. In a few of the older post-larvæ the rays of the first dorsal were just visible.

Post-larvæ occurred from June to September with a maximum in July and August. Spawning would thus be at its height in June and July. Post-larvæ of $A$. pellucida are seen to be widely distributed over the area investigated, though frequency is highest within the ten-fathom line.

TABLE XX.

Record of Aphya pelludida Nardo.

\begin{tabular}{|c|c|c|c|c|c|}
\hline \multicolumn{2}{|c|}{ No. of Haul. } & Date. & Depth. & No. & Size. \\
\hline II. & A & 6.vi.13 & B. & 53 & $7 \cdot 7-10 \cdot 5$ \\
\hline III. & A & 11.vi.13 & M. & 4 & $6 \cdot 02-11 \cdot 4$ \\
\hline V. & A & 12.vi.13 & M. & 4 & $6 \cdot 3-8$ \\
\hline IX. & A & 13.vi.13 & B. & 1 & $8 \cdot 4$ \\
\hline XXVI. & A & 8.vii.13 & - & 4 & $8 \cdot 5-10$ \\
\hline XXVII. & A & 10.vii.13 & S. & 1 & 9 \\
\hline XXVIII. & A & 11.vii.13 & M. & 8 & $8-11$ \\
\hline XXIX. & A & & S. & 1 & 11 \\
\hline XXXI. & A & 14.vii.13 & S. & 2 & $8 \cdot 3-8 \cdot 68$ \\
\hline XXXII. & A & 15.vii.13 & B. & 3 & $8.5-11 \cdot 5$ \\
\hline XXXIV. & A & 16.vii.13 & M. & 1 & 6 \\
\hline XXXV. & A & 17.vii.13 & S. & 21 & $6-14 \cdot 5$ \\
\hline XXXVI. & A & 18.vii.13 & M. & 5 & $6-9 \cdot 5$ \\
\hline XXXVII. & A & 24.vii.13 & B. & 7 & $5 \cdot 5-12$ \\
\hline XXXVIII. & A & & M. & 9 & $6 \cdot 5-12$ \\
\hline XL. & A & 28.vii.13 & M. & 12 & $10 \cdot 5-11$ \\
\hline XLI. & A & $"$ & M. & 61 & $8-16$ \\
\hline XLII. & A & , & M. & 11 & $6 \cdot 5-12 \cdot 5$ \\
\hline XLIII. & A & & S. & 5 & damaged \\
\hline XLIV. & A & 29.vii.13 & S. & 1 & $8 \cdot 5$ \\
\hline XLVI. & A & & M. & 32 & $7 \cdot 5-10 \cdot 5$ \\
\hline XLVII. & A & 30.vii.13 & S. & 1 & 11 \\
\hline XLVIII. & A & & B. & 14 & $4 \cdot 5-10 \cdot 5$ \\
\hline XLIX. & A & 31.vii.13 & B. & 3 & $7-7 \cdot 5$ \\
\hline LIII. & A & 1.viii.13 & S. & 17 & $4 \cdot 5-12$ \\
\hline LIV. & A & 2.viii.13 & S. & 33 & $4 \cdot 5-16$ \\
\hline LV. & A & ", & S. & 42 & $3-16 \cdot 5$ \\
\hline LVI. & A & , & M. & 23 & $5 \cdot 5-18$ \\
\hline LVII. & A & , & M. & 13 & $12 \cdot 5-16$ \\
\hline LVIII. & A & , & S. & 16 & $8-17$ \\
\hline LX. & A & 7.viii.13 & S. & 1 & $8 \cdot 5$ \\
\hline LXI. & A & $"$ & M. & 7 & $4-4 \cdot 5$ \\
\hline LXII. & A & , & B. & 13 & $5-7$ \\
\hline LXIII. & A & ",. & M. & 5 & $3 \cdot 14-8$ \\
\hline LXIV. & A & 11.vili.13 & M. & 3 & ca. 6 \\
\hline LXV. & A & 13.viii.13 & B. & 128 & $3 \cdot 68-125$ \\
\hline LXX1. & A & 13. .11.13 & S. & 128 & $4-14$ \\
\hline LXXIII. & $\stackrel{A}{A}$ & $"$ & $\begin{array}{l}\text { S. } \\
\text { S. }\end{array}$ & $\begin{array}{r}108 \\
49\end{array}$ & $\begin{array}{l}4.5-15 \\
4.5-2.5\end{array}$ \\
\hline & & & $\mathrm{D}$. & 49 & $4 \cdot 5-12 \cdot 5$ \\
\hline
\end{tabular}


LARVAL AND POST-LARVAL TELEOSTEANS.

TABLE XX.-Continued.

Record of Aphya pellucida Nardo.

\begin{tabular}{|c|c|c|c|c|}
\hline No. of Hanl. & Date. & Depth. & No. & Size. \\
\hline LXXIV. A & 13. viii. 13 & M. & 154 & $3-14$ \\
\hline LXXV. A & & S. & 8 & $5-15$ \\
\hline LXXVI. A & 14.viii.13 & S. & 14 & $4 \cdot 5-12$ \\
\hline LXXIX. A & 18.viii.13 & B. & 3 & $8 \cdot 5-11$ \\
\hline LXXXIX. A & 22.viii.13. & B. & 2 & $9-14 \cdot 5$ \\
\hline XC. A & & B. & 27 & $4 \cdot 5-14$ \\
\hline XCII. A & 25.viii. 13 & M. & 2 & $8-14 \cdot 5$ \\
\hline XCV. A & , & M. & 2 & $5 \cdot 5-9$ \\
\hline XCVI. A & , & B. & 2 & $8 \cdot 5-10$ \\
\hline XCVII. A & & B. & 4 & $5 \cdot 5-12$ \\
\hline XCIX. A & 26.viii.13 & M. & 2 & ca. 8 \\
\hline CI. A & 27.viii.13 & M. & 4 & $7 \cdot 5-9 \cdot 5$ \\
\hline CII. A & & M. & 1 & 11 \\
\hline CXI. A & 3.ix.13 & M. & 8 & $8-15$ \\
\hline CLVI. A & $20 . i x .13$ & M. & 3 & ca. 8 \\
\hline CLX. A & 22.ix.13 & B. & 1 & $15 \cdot 5$ \\
\hline CLXV. A & 24.ix.13 & B. & 1 & 19 \\
\hline CLXX. A & 25.ix.13 & B. & 1 & $6 \cdot 03$ \\
\hline CLXXIV. A & 26.ix.13 & B. & 1 & 7 \\
\hline CLXXIX. A & 29.ix.13 & B. & 3 & $8 \cdot 10$ \\
\hline CLXXXIV. A & 1.x.13 & B. & 1 & $19 \cdot 5$ \\
\hline
\end{tabular}

\section{COTTID丑.}

Cottus bubalis Euphr.

Spawning begins in January. Eggs were taken attached to stones between tide-marks on Drake's Island. Post-larvæ occurred from March to June, with their maximum in the last month.

\section{TABLE XXI.}

Record of CotTus bUBalts.

\begin{tabular}{|c|c|c|c|c|}
\hline No. of Haul. & Date. & Depth, & No. & Size. \\
\hline II. $\mathrm{H}$ & 22.v.06 & S. & 2 & $6-10$ \\
\hline III. $\mathrm{H}$ & & M. & 3 & $4 \cdot 5-8$ \\
\hline VIII. $\mathrm{H}$ & 30.v.06 & B. & 1 & $7 \cdot 5$ \\
\hline XI. $\bar{H}$ & 20.vi.06 & B. & 3 & ca. 8 \\
\hline XIV. H & & B. & 2 & $6 \cdot 5$ \\
\hline XVII. H & 28.vi.06 & B. & 1 & 5 \\
\hline XXXI. H & 25.iii.07 & S. & 6 & $7 \cdot 10$ \\
\hline XXXII. H & & M. & 1 & $7 \cdot 5$ \\
\hline XXXIII. H & 11.iv. 07 & M. & 4 & $4 \cdot 5-9$ \\
\hline XXXIV. H & & B. & 4 & $5 \cdot 5-11 \cdot 5$ \\
\hline XXXV. H & 6.vi.07 & B. & 6 & $6-8$ \\
\hline XLIV. $\mathrm{H}$ & 28.v.08 & $?$ & 2 & $5-7$ \\
\hline LVIII. H & 10.vi.08 & B. & 2 & $5 \cdot 5-6$ \\
\hline LXVI. H & 19.vi.08 & B. & 1 & 8 \\
\hline LXVII. H & , & S. & 4 & ca. 5 \\
\hline LXVIII. H & & B. & 2 & ca. 4 \\
\hline XXIV. H & 30.vi.08 & $?$ & 1 & 4 \\
\hline XCV. H & 28.iv.09 & S. & 7 & $3-6$ \\
\hline XCVI. H & & B. & 1 & 5 \\
\hline XCVII. H & 3.v.09 & ? & 1 & 4 \\
\hline XCIX. H & 13.v.09 & M. & 3 & $7-8$ \\
\hline CIV. H & 2.vi.09 & B. & 1 & 6 \\
\hline CIX. H & 25.vi.09 & S. & 2 & $7 \cdot 5-8$ \\
\hline
\end{tabular}




\section{CYCLOPTERID Æ.}

Cyclopterus lumpus L. Cyclogaster montagui Donov.

Cyclopterus lumpus $\mathrm{L}$.

Only one specimen of the lumpsucker is recorded. It was taken in the Zostera bed of Cawsand Bay in a midwater haul on 24th September, 1913. The total length was $18 \mathrm{~mm}$.

\section{Cyclogaster montagui Donov.}

Post-larvæ of this species occurred most frequently in June, at lengths ranging from 3 to $7.07 \mathrm{~mm}$. The capture of two specimens 5.6 and $6.7 \mathrm{~mm}$. in length in August and September, in bottom hauls, seems to suggest a long post-larval life. In these, the sucker was well developed in front of the abdomen, as in Ehrenbaum's Fig. C, "Nordisches Plankton," Vol. I.

\section{TABLE XXII.}

Record of Cyclogaster montagui.

\begin{tabular}{|c|c|c|c|c|}
\hline No. of Haul. & Date. & Denth. & Cyclogas & ter montagui. \\
\hline VI. H & $30 . v .06$ & B. & 4 & $4 \cdot 5-6$ \\
\hline VII. H & , & $\mathrm{S}$. & 1 & $7 \cdot 5$ \\
\hline VIII. $\mathrm{H}$ & & B. & 1 & ca. 8 \\
\hline XI. H & 20.vi.06 & B. & 1 & 7 \\
\hline XVII. $\bar{H}$ & 28.vi.06 & B. & 2 & $4 \cdot 5-6$ \\
\hline XX. H & 20.vii. 06 & B. & 1 & 6 \\
\hline XXI. $\mathrm{H}$ & 27.vii. 06 & B. & 1 & $5 \cdot 5$ \\
\hline XXXV. H & 6.vi.07 & B. & 6 & ca. 5 \\
\hline LIII. H & 4.vi.08 & S. & 1 & 6 \\
\hline LXVIII. H & 19.vi.08 & B. & 1 & 8 \\
\hline LXX. H & 23.vi.08 & M. & 1 & $6 \cdot 7$ \\
\hline LXXI. H & & B. & 2 & $4 \cdot 3$ \\
\hline CV. $\mathrm{H}$ & 10.vi.09 & B. & ? & ? \\
\hline CIX. H & 25.vi.09 & B. & 1 & 7 \\
\hline XIV. A & 18.vi.13 & B. & 1 & $7 \cdot 07$ \\
\hline XCVI. A & 25.viii.13 & B. & 1 & $5 \cdot 695$ \\
\hline CLX. A & 22.ix.13 & B. & 1 & $6 \cdot 7$ \\
\hline
\end{tabular}

TRIGLID A.

Trigla gurnardus L. T. hirundo Bl. T. cuculus L. T. lineata (Ray).

Our knowledge of post-larval gurnards is extremely limited. Only $T$. gurnardus and T. hirundo, two of the five species that occur at Plymouth, are known with any degree of certainty. Trigla gurnardus is well represented in the collection, and appears to be the commonest post-larval form. T. hirundo has been partially worked out by Emery* for the Mediterranean, and his descriptions of the post-

* Mittheil. Zool. Sta. Neapel, vi, 1886. 
larval forms have been extremely helpful. Specific characters which have been found most useful have reference to the pectoral fins. These are extremely long in $T$. gurnardus, and have the pigment scattered as black dots between the rays mostly on the posterior half of the fin. In $T$. hirundo the pectorals are much shorter and broader, more deeply pigmented over the whole surface, and appear almost as a uniform brownish black.

An entirely different form appears in August and September. This, by a process of elimination, is most probably $T$. lineata, which is known to spawn about July. The early post-larva has very little pigment except for a distinct narrow dark band along the dorsal and posterior margin of the abdominal region, somewhat similar to what occurs in Cottus bubalis.

With the material at my disposal, I hope to give a fuller account of the different species in a later contribution.

\section{TRACHINID $Æ$.}

Trachinus vipera Cuv. T. draco L.

T. vipera Cuv. (Lesser Weever.)

Pelagic post-larvæ of the lesser weever were found to be generally distributed and comparatively numerous. They were taken at the mouth of the Lynher River, in the Sound, Cawsand Bay, and over depths ranging from ten to about forty fathoms. The frequency was highest beyond the twenty-fathom line. They occurred from April to September, so that the spawning of this species, as with the dragonet, is indefinitely prolonged. The maximum for the post-larvæ lies in July and August.

\section{T. draco L. (Greater Weever.)}

Records of the greater weever are limited to four specimens from 6 to $7 \mathrm{~mm}$. in length, secured in August and September. The appearance of these post-larvæ corresponds to Ehrenbaum's Fig. f, " Nordisches Plankton," Vol. I. Adults of this species are by no means common in the neighbourhood. Those which have been observed have been captured in deeper water.

\section{TABLE XXIII.}

Record of Trachinus draco.

\begin{tabular}{rllccl} 
No. of Haul. & \multicolumn{1}{c}{ Date. } & Depth. & No. & $\begin{array}{l}\text { Size. } \\
\mathrm{mm}\end{array}$ \\
XCIX. & A. & $26:$ viii. 13 & M. & 2 & $6-7$ \\
CXVII. & A. & $5 . i x .13$ & M. & 1 & 6 \\
CLXXVI. & A. & $26 . i x .13$ & B. & 1 & $6 \cdot 5$
\end{tabular}




\section{CALLIONYMID $Æ$.}

\section{Callionymus lyra $\mathrm{L}$.}

Hefford recorded the eggs of the dragonet from 11th February to 30th August, but they have been observed this year in January. There is thus an indefinitely prolonged spawning period in the Plymouth district. This is borne out by the post-larval records, which extend from March to September, with a maximum for the middle months of the year-May, June, and July. The distribution of the post-larvæ is general, but there is a distinct concentration in numbers between the twenty and thirty fathom lines, where the adults are also very numerous. The frequency is low inshore within the twenty-fathom line. Between the ten and twenty fathom lines, and also between the thirty and forty, the percentage is fairly high, and shows only a slight decrease from the numbers in the area included between these two regions.

\section{GOBIESOCID $Æ$.}

Lepadogaster bimaculatus Donov. L. gouani Lacep. L. candollei Risso.

The distribution of these three species is well marked by the records in Table 24. There are two types represented - the littoral type in $L$. gouani and $L$. candollei, and the deeper water type in $L$. bimaculatus. The frequency of $L$. bimaculatus is high beyond the twenty-fathom line and low in depths less than twenty fathoms. Post-larval $L$. bimaculatus occurred from June to September with a maximum in July. Spawning thus begins in May and extends to August. Ova were frequently found in June and July attached to the inside of empty pecten shells taken in the otter trawl on the Eddystone Grounds. Adult males were generally in attendance.

\section{TABLE XXIV.}

Record of Lepadogaster sp.

\begin{tabular}{|c|c|c|c|c|c|c|c|c|}
\hline \multirow[b]{2}{*}{ No. of Haul. } & \multirow[b]{2}{*}{ Date. } & \multirow[b]{2}{*}{ Depth. } & \multicolumn{2}{|c|}{ L. bimaculatus. } & \multicolumn{2}{|c|}{ L. gouani. } & \multicolumn{2}{|c|}{ L. candollei. } \\
\hline & & & No. & Size. & No. & Size. & No. & Size. \\
\hline XIV. H & 20.vi.06 & B. & 12 & $7 \cdot 5-11$ & - & - & - & - \\
\hline XVII. $\bar{H}$ & 28.vi.06 & B. & 4 & $4-7$ & - & - & - & - \\
\hline XIX. H & 20.vii. 06 & $\mathrm{~S}$. & - & - & 1 & $5 \cdot 5$ & 19 & $4 \cdot 5-7 \cdot 5$ \\
\hline XX. $\bar{H}$ & & M. & 11 & $5 \cdot 5-10 \cdot 5$ & - & - & 2 & $5-6$ \\
\hline XXI. H & 27.vii.06 & $?$ & 25 & $5-10 \cdot 5$ & - & - & - & - \\
\hline XXII. $\mathrm{H}$ & & $?$ & 6 & $4 \cdot 7-10$ & - & - & 1 & 6 \\
\hline XXVIII. H & 21,ix.06 & B. & 1 & 17 & - & - & - & - \\
\hline XXXV. H & 6.vi.07 & B. & 9 & $6-10$ & - & - & - & - \\
\hline XXXIX. H & 10.vii. 07 & B. & 3 & $5-6$ & - & - & - & - \\
\hline XL. H & 19.vii. 07 & B. & 1 & 7 & - & - & - & - \\
\hline XLIII. H & 28.v.08 & M. & - & - & 3 & $5-6$ & - & - \\
\hline XCVII. H & 3.v.09 & ? & - & - & 1 & $4 \cdot 6$ & - & - \\
\hline CIV. H & 2.vi.09 & B. & 1 & 9 & - & - & - & - \\
\hline
\end{tabular}


TABLE XXIV.-Continued.

RECORD OF LEPADOGASTER SP.

\begin{tabular}{|c|c|c|c|c|c|c|c|c|c|}
\hline \multirow{2}{*}{\multicolumn{2}{|c|}{ No. of $\mathrm{Ha}$}} & \multirow{3}{*}{$\begin{array}{c}\text { Date. } \\
\text { 13.vii.09 }\end{array}$} & \multirow{3}{*}{ Depth. } & \multirow{2}{*}{\multicolumn{2}{|c|}{ L. bimaculatus. }} & \multirow{2}{*}{\multicolumn{2}{|c|}{ L. gouani. }} & \multirow{2}{*}{\multicolumn{2}{|c|}{ L. candollei. }} \\
\hline & & & & & & & & & \\
\hline CXVIII. & $\mathrm{H}$ & & & 3 & $6-7 \cdot 5$ & - & - & - & - \\
\hline CXXI. & $\mathrm{H}$ & 20.vii.09 & & 9 & $6-10$ & - & - & - & - \\
\hline CXXII. & $\mathrm{H}$ & & ? & 11 & $5-8$ & - & - & - & - \\
\hline CXXV. & $\mathrm{H}$ & 6.viii.09 & B. & 5 & $5-7 \cdot 5$ & - & - & - & - \\
\hline III. & A & 11.vi & $\ddot{r}$ & 1 & $5 \cdot 32$ & - & - & - & - \\
\hline V. & A & 12.v & M. & 1 & 6 & - & - & - & - \\
\hline $\mathrm{X}$. & A & 16.vi.13 & B. & - & - & 1 & $7 \cdot 46$ & - & - \\
\hline XXI. & A & 24. & S. & 1 & $5 \cdot 18$ & - & - & - & - \\
\hline XXV. & A & 7.vii & $\mathrm{B}$ & - & - & - & - & . 1 & $6 \cdot 02$ \\
\hline XLVI. & A & 29.vii.13 & M. & 1 & $8 \cdot 5$ & - & - & - & - \\
\hline XLVII. & A & 30.vii.13 & 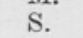 & - & - & - & - & 1 & 7.5 \\
\hline XLVIII. & A & & & - & - & - & - & 5 & $6-8$ \\
\hline XLIX. & A & 31.vii.13 & B & 1 & $9 \cdot 5$ & - & - & - & - \\
\hline LIII. & $\mathrm{A}$ & 1.v & S. & 1 & mtd. & - & - & - & - \\
\hline LVI. & A & 2.viii.13 & M. & 1 & 8 & - & - & - & 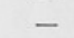 \\
\hline LVIII. & $\mathrm{A}$ & & S. & 8 & $5 \cdot 5-10$ & - & - & - & . \\
\hline LX. & A & 7.viii.13 & S. & - & - & - & - & 1 & $7 \cdot 5$ \\
\hline LXIII. & A & & & 2 & $6-6 \cdot 5$ & - & - & - & - \\
\hline LXXII. & A & 13. & & 8 & $5 \cdot 025-6 \cdot 62$ & & - & - & - \\
\hline LXXX. & A & 18.viii.13 & M. & - & - & 1 & $5 \cdot 5$ & 1 & 7 \\
\hline XC. & A & $22 . v$ & I & - & - & 1 & $6 \cdot 5$ & 1 & $7 \cdot 5$ \\
\hline XCII. & A & 25.viii. 13 & j & 1 & 10.5 & - & - & - & - \\
\hline XCV. & A & & $\mathrm{M}$ & 1 & 7 & - & - & - & - \\
\hline XCVI. & A & ," & & 1 & 6 & - & - & - & - \\
\hline XCVII. & A & ", & E & 3 & $5-7$ & - & - & - & - \\
\hline XCVIII. & A & & M & 1 & $7 \cdot 5$ & - & - & - & - \\
\hline CII. & A & 27.viii.13 & $N$ & 3 & 7 & - & - & - & - \\
\hline CXV. & A & 5.ix.1: & M. & 2 & $7 \cdot 5-9$ & - & - & 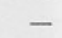 & . \\
\hline CXXVI. & A & $9 . \mathrm{ix} .13$ & B. & 1 & $5 \cdot 5$ & - & - & - & - \\
\hline
\end{tabular}

\section{BLENNIID $\&$.}

Blennius pholis L. B. ocellaris $\mathrm{L}$.

Considerable difficulty has been experienced in determining all the individuals specifically, owing to our incomplete knowledge of the early post-larval stages. Records will be found on Table 25, a general survey of which reveals the presence of two main types, those forms which occur most frequently offshore, and those with a higher frequency inshore. The offshore type is represented by $B$. ocellaris, the inshore chiefly by $B$. pholis.

Eggs of $B$. ocellaris were found continuously from June to August inside empty Buccinum shells which were trawled on the Eddystone Grounds. In nearly every case an adult blenny was taken in attendance. Several of these adults were measured and gave lengths of 120 and $130 \mathrm{~mm}$. 
TABLE

Explanation of $\propto \quad=$ several thousands. $\mathrm{m}=$ many.

v.m. = very many.

\begin{tabular}{|c|c|c|c|c|c|c|c|c|c|c|}
\hline \multirow[b]{2}{*}{ No. of Haul. } & \multicolumn{2}{|c|}{ Clupea sp. } & \multicolumn{2}{|c|}{ Ammodytes sp. } & \multicolumn{2}{|c|}{ Labrus bergylta. } & \multicolumn{2}{|c|}{$\begin{array}{l}\text { Ctenolabrus } \\
\text { rupestris. }\end{array}$} & \multicolumn{2}{|c|}{ Arnoglossus sp. } \\
\hline & No. & Size. & No. & Size. & No. & Size. & & Size. & No. & Size. \\
\hline I. $\mathrm{H}$ & - & - & - & - & - & - & - & - & - & - \\
\hline II. $\mathrm{H}$ & - & - & - & - & - & $=$ & - & - & - & - \\
\hline IIII. H & 19 & $12-24$ & 4 & $10-29$ & 3 & 7 & - & - & - & - \\
\hline IV. $\mathrm{H}$ & 3 & $9-10$ & - & - & - & - & - & - & - & - \\
\hline V. H & 70 & $18-30$ & - & - & $=$ & $=$ & - & - & - & - \\
\hline VI. $\mathrm{H}$ & 7 & $9-16 \cdot 5$ & 14 & $6-17 \cdot 5$ & 7 & $4 \cdot 5-7$ & - & - & - & - \\
\hline VII. H & $\propto$ & $26-47$ & 1 & 12 & - & - & - & - & - & - \\
\hline VIII. H & 1 & $11 \cdot 5$ & 1 & 10 & - & - & - & - & - & - \\
\hline IX. H & 1 & 22 & 1 & $10 \cdot 5$ & 2 & 4 & - & - & 1 & $4 \cdot 5$ \\
\hline X. H & 4 & $10-12$ & 2 & $9-15$ & 3 & $4 \cdot 7-6$ & - & - & 1 & $4 \cdot 5$ \\
\hline XI. H & 4 & $17-20$ & 1 & 11 & 1 & 6 & - & - & - & \\
\hline XII. H & 7 & $12-17 \cdot 5$ & 1 & 10 & - & - & - & - & 2 & $5 \cdot 5-7$ \\
\hline XIII. $\vec{H}$ & 23 & $12-20$ & 3 & $10-17$ & - & - & - & - & - & - \\
\hline XIV. $\mathrm{H}$ & 1 & 13 & - & - & 1 & 24 & 5 & $3 \cdot 9-4 \cdot 5$ & 1 & $5 \cdot 5$ \\
\hline XV. H & 5 & $9-11$ & 1 & $7 \cdot 6$ & 60 & $3 \cdot 7-5 \cdot 5$ & 14 & $3 \cdot 8-4 \cdot 5$ & 1 & 4 \\
\hline XVI. H & 66 & $10 \cdot 5-19$ & 28 & $6 \cdot 5-18$ & 4 & $4-7 \cdot 5$ & - & - & 3 & $5-7 \cdot 5$ \\
\hline XVII. H & $1^{-}$ & 18 & - & - & - & - & - & - & - & - \\
\hline XVIII. H & 22 & $11-24$ & 3 & $7-12.5$ & 56 & $3 \cdot 25-7$ & 7 & $5-8$ & - & - \\
\hline XIX. H & 23 & $10 \cdot 5-16 \cdot 5$ & 4 & $7-16.5$ & - & - & 3 & $6 \cdot 5-8$ & 1 & $6 \cdot 5$ \\
\hline XX. H & 7 & $15-20$ & 12 & $8-23$ & 1 & $7 \cdot 3$ & 3 & 8 & - & - \\
\hline XXI. H & i & 12.5 & 1 & 17 & 3 & $4 \cdot 2-7$ & 1 & $7 \cdot 5$ & - & - \\
\hline XXII. H & - & - & - & - & - & - & - & - & - & - \\
\hline XXIII. H & - & - & - & - & - & - & - & - & - & - \\
\hline XXIV. H & - & - & - & - & - & - & - & - & 18 & $13-26$ \\
\hline XXV.H & - & - & - & - & - & - & - & - & 1 & $26 \cdot 5$ \\
\hline XXVI. H & - & - & - & - & - & - & - & - & 2 & $19-21$ \\
\hline XXVII. H & 2 & $4 \cdot 5-18$ & 1 & 15 & - & - & - & - & - & - \\
\hline XXVIII. H & - & - & - & - & - & - & - & - & - & - \\
\hline XXIX. H & - & $\overline{-}$ & - & - & - & - & - & - & - & - \\
\hline XXX. H & 1 & 7 & - & - & - & - & - & - & - & - \\
\hline XXXI. $\bar{H}$ & 14 & $10-20$ & 1 & 8.5 & - & - & - & - & - & - \\
\hline XXXII. H & 10 & $3-5$ & - & - & - & - & - & - & - & - \\
\hline XXXIII. H & 15 & $5-14 \cdot 5$ & 3 & $6 \cdot 5-12 \cdot 5$ & - & - & - & - & - & - \\
\hline XXXIV. H & 5 & $7-11$ & 3 & $7-8$ & - & - & - & - & - & - \\
\hline XXXV. H & 3 & $9-12$ & - & - & 2 & 4 & - & - & - & - \\
\hline XXXVI. H & - & - & - & - & - & - & - & - & - & - \\
\hline XXXVII. H & - & - & - & - & 1 & 5 & - & - & - & - \\
\hline XXXVIII. H & - & - & - & - & 6 & - & - & - & - & - \\
\hline XXXIX. H & 1. & 16 & - & - & 1 & - & - & - & - & - \\
\hline XL. H & $\overline{0}$ & - & 12 & $13-22$ & 2 & $8-20$ & - & - & - & - \\
\hline XLI. H & 20 & $9-18$ & - & - & - & - & - & - & - & - \\
\hline XLII. H & 8 & 4 & - & - & - & - & - & - & - & - \\
\hline XLIII. $\mathrm{H}$ & - & - & - & - & - & - & - & - & - & - \\
\hline XLIV. H & 27 & $11-21$ & - & - & 3 & $5-7 \cdot 5$ & - & - & - & - \\
\hline XLV. H & - & - & - & - & - & - & - & - & - & - \\
\hline XLVI. H & 4 & $10-12$ & - & - & - & - & - & - & - & - \\
\hline XLVII. H & 6 & $12-16$ & 1 & 23 & - & - & - & - & - & - \\
\hline XLVIII. H & 1 & 10 & 1 & 11 & - & - & - & - & - & - \\
\hline XLIX. H & 2 & $12 \cdot 5-13 \cdot 5$ & - & - & - & - & - & - & - & - \\
\hline L. $\mathrm{H}$ & 7 & $10-17$ & 7 & $7-12 \cdot 5$ & - & - & - & - & - & - \\
\hline LI. H & 2 & $8-9$ & - & - & - & - & - & - & - & - \\
\hline LII. H & - & $-\overline{-}$ & - & - & - & - & - & $=$ & - & - \\
\hline LIII. H & 30 & $7 \cdot 5-16$ & - & - & - & - & 1 & $7 \cdot 5$ & - & - \\
\hline LIV. $\mathrm{H}$ & 2 & $13-16$ & - & - & - & - & - & - & - & - \\
\hline LV. H & - & - & - & - & - & - & - & - & - & - \\
\hline
\end{tabular}


XXV.

AbBreviations.

$\mathrm{z} \quad=$ damaged specimen.

size $=$ length in $\mathrm{mm}$.

\begin{tabular}{|c|c|c|c|c|c|c|c|c|c|c|c|}
\hline \multicolumn{2}{|c|}{$\begin{array}{l}\text { Scophthalmus } \\
\text { norvegicus. }\end{array}$} & \multicolumn{2}{|c|}{ Gobius sp. } & \multicolumn{2}{|c|}{ Trigla sp. } & \multicolumn{2}{|c|}{$\begin{array}{c}\text { Trachinus } \\
\text { vipera. }\end{array}$} & \multicolumn{2}{|c|}{$\begin{array}{l}\text { Callionymus } \\
\text { lyra. }\end{array}$} & \multicolumn{2}{|c|}{ Blennius sp. } \\
\hline No. & Size. & No. & Size. & No. & Size. & No. & Size. & No. & Size. & No & Size \\
\hline - & - & - & - & - & - & - & - & - & - & - & - \\
\hline - & - & 1 & $7 \cdot 3$ & - & - & - & - & 7 & $4-6$ & - & - \\
\hline- & - & 22 & $5-9$ & - & - & - & - & 180 & $3-7$ & - & - \\
\hline 25 & $5-8$ & 2 & ? & - & - & - & - & 54 & $2 \cdot 5-5$ & - & - \\
\hline 1 & $10 \cdot 5$ & 2 & $7-15$ & 2 & $9-10$ & - & - & 9 & $3 \cdot 2-7$ & 1 & $5 \cdot 5$ \\
\hline 19 & $4-9$ & 8 & $4-8$ & 13 & $7-11 \cdot 5$ & 1 & $3 \cdot 5$ & $\mathrm{~m}$. & $3-7$ & 1 & $5 \cdot 5$ \\
\hline- & - & - & - & - & - & - & - & 2 & $6 \cdot 5$ & - & - \\
\hline- & - & $\mathrm{m}$. & $6-17$ & - & - & - & - & 3 & 7-9 & - & - \\
\hline- & - & - & - & - & - & 1 & $3 \cdot 5$ & 8 & $3 \cdot 5-7$ & 5 & ca. $4 \cdot 5$ \\
\hline- & - & 3 & $4-4 \cdot 5$ & - & - & 7 & $3 \cdot 5-5$ & 1 & $3 \cdot 5$ & 20 & $4 \cdot 6-6$ \\
\hline- & $\overline{-}$ & 150 & $5-13$ & 1 & $7 \cdot 5$ & - & - & 9 & $3 \cdot 5-7$ & - & - \\
\hline 1 & 7 & - & - & - & - & - & - & - & - & - & - \\
\hline 3 & $5 \cdot 5-6$ & 26 & $6-10$ & - & - & - & - & 42 & $3-8$ & - & - \\
\hline - & - & 40 & $4 \cdot 5-11 \cdot 5$ & 5 & $5 \cdot 5-7 \cdot 5$ & 6 & $4-4 \cdot 7$ & 37 & $3 \cdot 5-7 \cdot 5$ & - & - \\
\hline- & - & 2 & ca. $5 \cdot 5$ & - & - & 16 & $3-4$ & - & - & 67 & $4 \cdot 7-6 \cdot 5$ \\
\hline 28 & $4 \cdot 5-9$ & 10 & $3-6 \cdot 3$ & - & - & - & - & 4 & $2 \cdot 5-4$ & 20 & $4-6$ \\
\hline - & - & 200 & $3 \cdot 5-10$ & 38 & $7 \cdot 5-11$ & 1 & $3 \cdot 7$ & 100 & $3 \cdot 5-?$ & 15 & $4 \cdot 5-9$ \\
\hline- & - & 4 & $7-11$ & 1 & 8.5 & 19 & $3 \cdot 5-6 \cdot 5$ & 4 & $3-5$ & 7 & $4-8$ \\
\hline 3 & $5-6$ & - & - & 4 & $7 \cdot 5-12$ & 3 & $3 \cdot 5-5$ & 55 & $2 \cdot 5-8$ & - & - \\
\hline 1 & 6 & 168 & $3 \cdot 5-16$ & 3 & $5-8 \cdot 5$ & 3 & $6-7 \cdot 5$ & 55 & $3-8$ & 1 & 6 \\
\hline- & - & 160 & $5-13$ & 4 & $7-12$ & 2 & $4-6$ & 30 & $3 \cdot 5-8$ & 1 & 8 \\
\hline - & - & 31 & $4-10$ & - & - & - & - & 4 & $3 \cdot 5-5 \cdot 5$ & 1 & 4 \\
\hline- & - & - & - & - & - & - & - & - & - & - & - \\
\hline- & - & - & - & - & - & - & - & - & - & - & - \\
\hline- & - & - & - & - & - & - & - & - & - & - & - \\
\hline- & - & - & - & - & - & - & - & - & - & - & - \\
\hline- & - & - & - & - & - & - & - & - & - & - & - \\
\hline- & - & - & - & 1 & - & - & - & - & - & - & - \\
\hline - & - & - & - & - & - & - & - & - & - & - & - \\
\hline- & - & - & - & - & - & - & - & - & - & - & - \\
\hline- & - & - & - & - & - & - & - & 13 & $2 \cdot 5-?$ & - & - \\
\hline - & - & - & - & - & - & - & - & 23 & $2 \cdot 5-6$ & - & - \\
\hline- & - & - & - & 1 & 5 & 1 & $3 \cdot 5$ & 23 & $2 \cdot 5-7$ & - & - \\
\hline- & - & - & - & 1 & 7 & - & - & 8 & $3-6$ & - & - \\
\hline 2 & $5-8$ & 12 & $5-8$ & 3 & $7 \cdot 5-17$ & - & - & 79 & $2 \cdot 5-8$ & - & - \\
\hline - & - & - & - & - & - & - & - & - & - & - & - \\
\hline- & - & - & - & - & - & - & - & - & - & 14 & - \\
\hline 1 & 6 & - & - & - & - & - & - & $\bar{z}$ & - & 19 & - \\
\hline 4 & $6-9$ & 10 & $7-9$ & 1 & 17 & - & - & 5 & ca. 5 & - & - \\
\hline- & - & 1 & 12 & 2 & $10-17$ & - & - & 3 & 4-9 & - & - \\
\hline 28 & - & - & - & - & - & - & - & - & - & - & - \\
\hline- & - & - & - & - & - & - & - & 1 & 4 & - & - \\
\hline 80 & - & - & - & - & - & - & - & - & - & - & $=$ \\
\hline 6 & $5-8 \cdot 5$ & 70 & $4 \cdot 5-10$ & - & - & - & - & 80 & $3-7$ & 2 & $4 \cdot 5-5$ \\
\hline- & - & 1 & 6 & - & - & - & - & 3 & $3-5$ & 1 & 5 \\
\hline- & - & 6 & 4-5 & 2 & $10-17$ & - & - & 3 & ca. 4 & 1 & 5 \\
\hline- & - & 14 & $4-7 \cdot 5$ & 3 & $8-9$ & - & - & 12 & $3 \cdot 67$ & - & - \\
\hline - & - & - & - & - & - & - & - & 11 & $3-5$ & - & - \\
\hline- & - & 1 & 5 & - & - & - & - & 4 & $4-7$ & - & - \\
\hline- & - & 4 & $5-8 \cdot 5$ & - & - & - & - & 8 & $3-7 \cdot 2$ & - & - \\
\hline- & - & 54 & $3 \cdot 2-15$ & - & - & - & - & - & - & - & $\bar{z}$ \\
\hline- & - & 720 & $4-11$ & $\overline{3}$ & $\bar{c}$ & - & - & 2 & $3-6$ & 1 & 5 \\
\hline 14 & $5 \cdot 5-8 \cdot 2$ & 32 & $4-7 \cdot 8$ & 1 & 6 & - & - & 7 & $2 \cdot 7-5$ & 1 & 5 \\
\hline- & - & 1 & 11 & - & - & - & - & 2 & $4-5$ & - & - \\
\hline - & - & 1 & $4 \cdot 5$ & - & - & - & - & 4 & $3-5$ & - & - \\
\hline
\end{tabular}


TABLE XXV.-

No. of Haul Clupea sp. Ammodytes sp. Labrus bergyita. LVI. $\mathrm{H}$ LVII. H LVIII. H 32 LIX. H 8 LX. H 17 LXI. H 9 LXII. H 2 LXIII. H 3 LXIV. H 11 LXV. H 19 LXVI. H 25 LXVII. H 1 LXVIII. H 2 LXIX. H LXX. H 53 LXXI. H m. LXXII. H LXXIII. H LXXIV. H 8 LXXV. H 6 LXXVI. H 1 LXXVII. H 18 LXXVIII. H LXXIX. H 6 $\begin{array}{lc}\text { LXXX. H } & 40 \\ \text { LXXXI. H } & 2\end{array}$ $\begin{array}{ll}\text { LXXXI. H } & 2 \\ \text { LXXXII. H } & 3\end{array}$ LXXXIII. H LXXXIV. H 1 LXXXV. H LXXXVI. H LXXXVIII. H LXXXIX. H XC. $\mathrm{H}-$ XCI. $\mathrm{H}-$ XCII. $\mathrm{H}-$ XCIII. $\mathrm{H}-$ XCIV. H 3 XCV. $\mathrm{H} 2$ XCVI. H 5 XCVII. $\mathrm{H}$

XCVIII. H 5 XCIX. H 4 C. $\mathrm{H} \quad \mathrm{I}$ CI. $\mathrm{H} 3$ CII. $\mathrm{H}-$ CIII. H 18 CIV. H 20 CV. $\mathrm{H}-$ CVI. $\mathrm{H}-$ CVII. H CVIII. $\mathrm{H}$ I CIX. H 4 $\begin{array}{cc}\text { CX. H } & 3 \\ \text { CXI. H } & 52\end{array}$ $\begin{array}{ll}\text { CXI. H } & 52 \\ \text { CXII. H } & 12\end{array}$ CXIII. H 6 CXIV. H -

$$
\begin{aligned}
& \text { Size. No. Size. No. Size. No. Size. No. Size. }
\end{aligned}
$$

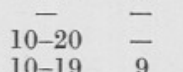

$$
\begin{aligned}
& \text { 7-15 } \\
& \begin{array}{cccc}
8-15 & 14 & 6-10 & - \\
10-18 & 1 & 7 & 7
\end{array} \\
& -18 \\
& 10-14- \\
& \text { 9-1 } \\
& \text { 11-23 } \\
& \text { 11-23 } \\
& 9-24 \\
& 10-12 \\
& -\quad 2 \\
& \text { 17-18 } 29 \\
& \text { 8-20 } \\
& - \\
& \text { 8-15 } \\
& \text { 9-11 } \\
& 10 \\
& \text { 23-27 - } \\
& \text { 13-15 } 11 \\
& \text { 10-15 } 8 \\
& 7-10 \quad 68 \\
& 7 \cdot 5-12 \\
& \overline{17} \quad \overline{3} \\
& \begin{array}{l}
17 \\
-\quad 3 \\
-\quad 13
\end{array} \\
& \text { - } 13 \\
& \text { - } 6 \\
& \text { - } \\
& \text { - } \\
& \overline{20} \\
& \text { 20 } \\
& 8-15- \\
& 24 \\
& \text { 22-26 } \\
& \text { 12-17 } \\
& 20 \\
& \text { 22-27 } \\
& \text { 12-17 - } \\
& \text { 12-17 } \\
& \text { - - } \\
& \text { 41 } \\
& \text { 18-21 } 1 \\
& \text { 12.5-17 - } \\
& \text { 17-21 } 4 \\
& \text { 10-20 } 2 \\
& - \\
& 5 \cdot 5-9 \\
& \begin{array}{ccccc}
-711 & - & - & - & - \\
5-6 & - & - & - & -
\end{array} \\
& \text { - } 3 \\
& \text { 11-15 } \\
& \text { 7-9 - } \\
& \begin{array}{ll}
14 & -
\end{array} \\
& \text { 7-11 } \\
& \text { 6-21 } \\
& \begin{array}{ll}
6 & 5 \\
- & 17
\end{array} \\
& \begin{array}{cc}
- & 1 \\
- & 6 \\
7 \cdot 5-13 & 3
\end{array} \\
& \text { 7-9 } \\
& \begin{array}{l}
-4 \\
-\quad 4
\end{array} \\
& \text { 6-13 } \\
& \text { 8-13 71 } \\
& \text { 5-20 } \\
& \text { 5-12.5 } 17 \\
& \text { 9-17 } \quad 19 \\
& \text { 7-13 - } \\
& \text { 8-17.5 - } \\
& \text { 5-16 } 1 \\
& \text { 7-17 } 1 \\
& \begin{array}{cc}
7 & 2 \\
19 & -
\end{array} \\
& \text { - } \\
& 4-7 \cdot 5 \\
& \text { - } \\
& \begin{array}{ccccc}
-\overline{5}-5 & - & - & - & - \\
3-8.5 & - & -
\end{array} \\
& 3 \cdot \overline{7}-7 \quad- \\
& \text { 7-12 } \\
& 4 \\
& - \\
& 5 \cdot 5-6 \cdot 8 \\
& 3 \cdot \overline{5}-5 \quad \overline{1} \\
& \text { 3-10 - } \\
& \begin{array}{cc}
6-7 \cdot 5 & - \\
3 \cdot 7-5 \cdot 5 & 2
\end{array} \\
& 3 \cdot 5-1 \\
& -\overline{14}- \\
& 4 \cdot 5-7 \quad 4 \\
& \text { - } 1 \\
& \frac{-}{-} \quad- \\
& \begin{array}{ccccc}
9 & \overline{5} & 5 \cdot 5-7 \cdot 3 & - & - \\
4 & \overline{1} & 3 \cdot 9
\end{array} \\
& \begin{array}{llcll}
- & \overline{2} & 7.5-8.5 & - & -
\end{array} \\
& \begin{array}{ccccc}
- & - & - & - & - \\
3 \cdot 5-4 & - & - & - & -
\end{array} \\
& \begin{array}{lllll}
- & - & - & - & - \\
- & - & - & - & -
\end{array} \\
& 1 \\
& 2 \\
& \begin{array}{llllll}
- & - & - & - & - & - \\
- & - & - & - & - & -
\end{array} \\
& \text { I } \\
& \begin{array}{lllllll}
- & \overline{1} & \overline{1} & - & - & - & - \\
- & 1 & 10 & - & - & - & -
\end{array}
\end{aligned}
$$

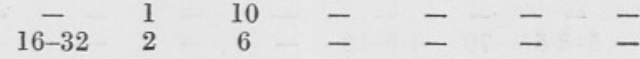

$$
\begin{aligned}
& \begin{array}{ccccccc}
- & 1 & 8 & - & - & - & - \\
- & - & - & - & - & - & - \\
- & - & - & - & - & - & - \\
\overline{10} & \overline{1} & \overline{9} & - & - & - & - \\
\overline{-} & 1 & 5 \cdot 5 & - & - & - & - \\
16 & 1 & 10 & - & - & - & - \\
15-17 & 1 & 6 & - & - & - & - \\
- & - & - & - & - & - & - \\
- & - & - & - & - & - & - \\
- & - & - & - & - & - & -
\end{array}
\end{aligned}
$$


Continued.

\begin{tabular}{|c|c|c|c|c|c|c|c|c|c|c|c|}
\hline \multicolumn{2}{|c|}{$\begin{array}{l}\text { Scophthalmus } \\
\text { norvegicus. }\end{array}$} & \multicolumn{2}{|c|}{ Gobius sp. } & \multicolumn{2}{|c|}{ Trigla sp. } & \multicolumn{2}{|c|}{$\begin{array}{l}\text { Trachinus } \\
\text { vipera. }\end{array}$} & \multicolumn{2}{|c|}{$\begin{array}{c}\text { Callionymus } \\
\text { lyra. }\end{array}$} & \multicolumn{2}{|c|}{ Blennius sp. } \\
\hline No. & Size. & No. & Size. & No. & Size. & No. & Size. & No. & Size. & No. & Size. \\
\hline 7 & $5-9$ & 16 & $4-8 \cdot 5$ & - & - & - & - & 6 & $2 \cdot 7-?$ & 1 & 5 \\
\hline - & - & 1 & 7 & - & - & - & - & 3 & $2 \cdot 8-6$ & - & - \\
\hline 3 & 4-9 & $\mathrm{m}$. & $4-9$ & - & - & - & - & $\mathrm{m}$. & $3-8$ & - & - \\
\hline - & - & 2 & ca. 7 & 1 & 6 & - & - & 15 & $3 \cdot 2-6 \cdot 5$ & 2 & $6-7 \cdot 5$ \\
\hline - & - & 51 & $3 \cdot 5-15$ & 3 & $6-7 \cdot 3$ & - & - & $\mathrm{m}$. & $3-8$ & - & - \\
\hline 2 & $5-6$ & 44 & $4-12$ & 1 & $7 \cdot 5$ & - & - & $\mathrm{m}$. & $3 \cdot 5-10$ & - & - \\
\hline - & - & - & - & - & - & - & - & - & - & - & - \\
\hline - & - & 6 & $5-13$ & 1 & 5 & - & - & - & - & - & - \\
\hline - & - & 1 & 11 & - & - & 1 & 5 & 2 & $3 \cdot 5-5$ & 17 & $3-6 \cdot 7$ \\
\hline 10 & $5-9$ & v.m. & $4-8$ & 4 & $4-10$ & - & - & $\mathrm{m}$. & $3-9$ & - & - \\
\hline 7 & $7-11$ & v.m. & $4-15$ & 3 & $7-10$ & - & - & v.m. & $3-9$ & - & - \\
\hline - & - & 20 & $4-8$ & - & - & 1 & $2 \cdot 5$ & - & - & 2 & $5-6$ \\
\hline - & - & $\mathrm{m}$. & $4-7 \cdot 3$ & 2 & $7-9 \cdot 5$ & - & - & 3 & $4 \cdot 5-8$ & 6 & $5-7 \cdot 5$ \\
\hline - & - & - & - & - & - & - & - & 4 & $2-4$ & - & - \\
\hline 58 & $3 \cdot 5-11$ & 84 & $3-9$ & 29 & $5-17$ & 3 & $3 \cdot 7-7$ & 50 & $3-8$ & 1 & $5 \cdot 4$ \\
\hline - & - & $\mathrm{m}$. & $5-12$ & 6 & ca. 16 & 1 & 4 & v.m. & $2 \cdot 7-10$ & - & - \\
\hline - & - & 2 & ca. 13 & 1 & $7 \cdot 5$ & - & - & - & - & - & - \\
\hline - & - & 60 & $8-26$ & - & - & - & - & - & - & 2 & $4-6$ \\
\hline 17 & $3 \cdot 7-6$ & 8 & $4-7$ & - & - & - & - & - & - & - & - \\
\hline 10 & $5-7$ & $\mathrm{~m}$. & $4-8$ & - & - & 1 & 3 & v.m. & $2 \cdot 5-?$ & - & - \\
\hline 1 & 4 & 24 & $3 \cdot 5-5$ & 1 & $5 \cdot 2$ & 1 & $4 \cdot 5$ & 5 & $2 \cdot 8-7 \cdot 5$ & 7 & $4 \cdot 5-6$ \\
\hline - & - & v.m. & $4-14$ & 1 & 10 & - & - & - & - & - & - \\
\hline- & - & 6 & $3 \cdot 7-13$ & - & - & - & - & - & - & 1 & $4 \cdot 5$ \\
\hline - & - & 9 & $3-6$ & - & - & 2 & $3 \cdot 3-5 \cdot 2$ & 2 & $4-6$ & 12 & $4-6$ \\
\hline- & - & 120 & $3-11$ & 1 & 11 & - & - & 21 & $2 \cdot 5-8$ & 1 & $4 \cdot 5$ \\
\hline - & - & 3 & $3-4 \cdot 5$ & - & - & - & - & 20 & $2 \cdot 2-4$ & 2 & $4 \cdot 5-5$ \\
\hline - & - & 15 & $2 \cdot 8-6$ & - & - & 2 & $4-5$ & 1 & 3 & 14 & $4-5 \cdot 5$ \\
\hline - & - & - & - & - & - & 4 & $3-4$ & - & - & - & - \\
\hline- & - & 4 & $5 \cdot 5-7$ & - & - & - & - & - & - & 2 & $7-8$ \\
\hline - & - & - & - & - & - & - & - & 2 & $3 \cdot 8-5$ & - & - \\
\hline- & - & 10 & $3 \cdot 7-5$ & - & - & 1 & 5 & 2 & $3 \cdot 3-7$ & 1 & 7 \\
\hline - & - & 5 & $4-6$ & - & - & 1 & 5 & 1 & 5 & - & - \\
\hline - & - & 2 & $6-8$ & - & - & - & - & - & - & - & - \\
\hline - & - & 3 & $5-7$ & - & - & - & - & - & - & - & - \\
\hline- & - & 7 & $6 \cdot 5-11 \cdot 5$ & - & - & - & - & - & - & - & - \\
\hline - & - & 10 & $10-11$ & - & - & - & - & - & - & - & - \\
\hline - & - & 1 & 9 & - & - & - & - & - & - & - & - \\
\hline - & - & 9 & $4 \cdot 5-7$ & - & - & - & - & - & - & - & - \\
\hline- & - & 11 & $3 \cdot 7-8$ & - & - & - & - & - & - & - & - \\
\hline- & - & 2 & $2 \cdot 6-6$ & - & - & - & - & 1 & 12 & - & - \\
\hline- & - & 52 & $3 \cdot 5-10$ & - & - & - & - & - & - & - & - \\
\hline- & - & 62 & $2 \cdot 7-9$ & - & - & - & - & 7 & $3 \cdot 7$ & - & - \\
\hline- & - & - & - & - & - & - & - & - & - & - & - \\
\hline- & - & 4 & $6-8 \cdot 5$ & - & - & - & - & 12 & $4 \cdot 7$ & - & - \\
\hline- & - & 1 & 4.5 & - & - & - & - & - & - & - & - \\
\hline- & - & - & - & - & - & - & - & 3 & $4 \cdot 5$ & - & - \\
\hline- & - & 1 & $7 \cdot 5$ & - & - & - & - & 5 & $5-8 \cdot 5$ & - & - \\
\hline- & - & 2 & $7-8$ & 2 & $7 \cdot 5-9$ & - & - & 19 & $3 \cdot 7-7 \cdot 5$ & - & - \\
\hline 3 & $6-8$ & 5 & $7-8$ & 15 & $7-10$ & - & - & v.m. & $4 \cdot 5-8$ & - & - \\
\hline- & - & - & - & - & - & - & - & - & - & - & - \\
\hline- & - & 7 & $8-13$ & - & - & - & - & - & - & - & - \\
\hline- & - & 1 & $7 \cdot 5$ & - & - & - & - & - & - & - & - \\
\hline- & - & 2 & $9-13$ & - & - & - & - & - & - & - & - \\
\hline- & - & - & - & - & - & - & - & - & - & - & - \\
\hline 2 & $6 \cdot 5$ & 4 & $7-8$ & 4 & $7 \cdot 5-12$ & - & - & v.m & $3 \cdot 5-8$ & - & - \\
\hline- & - & - & - & - & - & 1 & $6 \cdot 5$ & - & - & 24 & $4 \cdot 5-9$ \\
\hline- & - & 2 & $4-8$ & - & - & 5 & $4-5$ & 3 & $5 \cdot 5-6$ & 2 & $7-7 \cdot 5$ \\
\hline 10 & 7-9 & 3 & $4-8$ & 1 & $7 \cdot 5$ & - & - & 14 & $3 \cdot 5-7 \cdot 5$ & 1 & 8 \\
\hline- & - & - & - & - & - & - & - & - & - & - & - \\
\hline- & - & 17 & $7-16$ & - & - & - & - & - & - & - & - \\
\hline
\end{tabular}


TABLE XXV.-

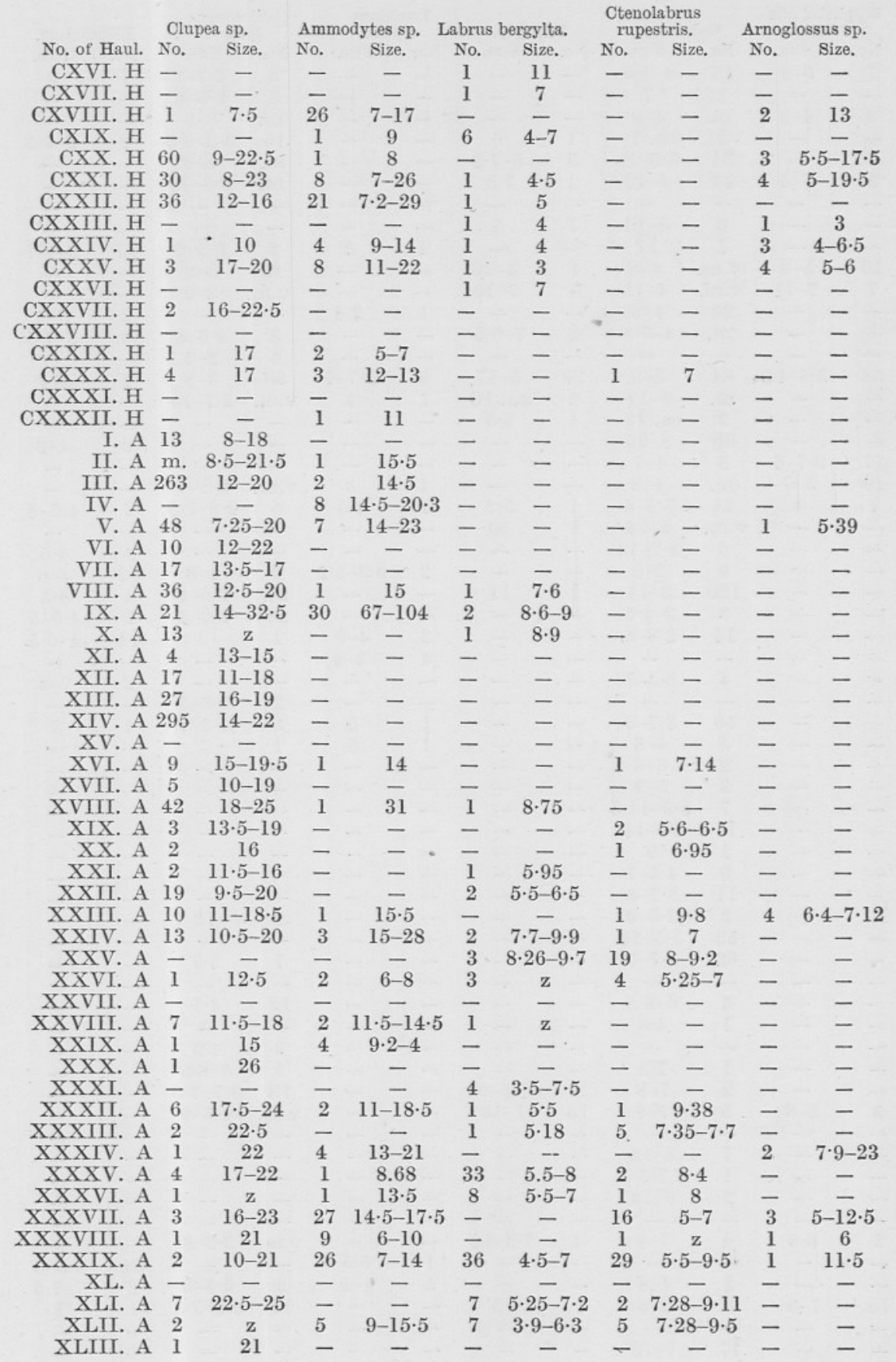


Continued.

\begin{tabular}{|c|c|c|c|c|c|c|c|c|c|c|c|}
\hline \multicolumn{2}{|c|}{$\begin{array}{l}\text { Scophthalmus } \\
\text { norvegicus. }\end{array}$} & \multicolumn{2}{|c|}{ Gobius sp. } & \multicolumn{2}{|c|}{ Trigla sp. } & \multicolumn{2}{|c|}{$\begin{array}{l}\text { Trachinus } \\
\text { vipera. }\end{array}$} & \multicolumn{2}{|c|}{$\begin{array}{c}\text { Callionymus } \\
\text { lyra. }\end{array}$} & \multicolumn{2}{|c|}{ Blennius sp. } \\
\hline No. & Size. & No. & Size. & No. & Size. & No. & Size. & No. & Size. & No. & Size. \\
\hline- & - & - & - & - & - & 1 & 5 & - & - & - & - \\
\hline- & - & 7 & $4-6$ & - & - & 3 & $3 \cdot 5-5$ & 3 & $3 \cdot 7-5$ & 16 & $5 \cdot 2-7$ \\
\hline - & - & - & - & - & - & 1 & 4 & 1 & $7 \cdot 5$ & 3 & ca. 6 \\
\hline- & - & 2 & ca. 9 & - & - & 2 & $4-6$ & - & - & 24 & $4-7$ \\
\hline- & - & 50 & $3 \cdot 7-21$ & - & - & 30 & $3-7$ & 5 & $4-5 \cdot 5$ & 6 & $4 \cdot 8-6 \cdot 5$ \\
\hline 2 & $7-10$ & - & - & 1 & $7 \cdot 5$ & 6 & $4 \cdot 5$ & 50 & $3-10$ & 2 & $5-8$ \\
\hline 6 & $8-10$ & $\mathrm{~m}$. & 4-25 & 6 & $7-11$ & 4 & $4-7$ & 40 & $4-10$ & 1 & 6 \\
\hline- & - & - & - & - & - & - & - & 2 & $3-5$ & - & - \\
\hline- & - & 2 & $5-10$ & 1 & 4 & 4 & $4-5$ & 14 & $3-7$ & 2 & $5 \cdot 5-8$ \\
\hline 2 & $5-6 \cdot 7$ & 23 & $3 \cdot 7-13$ & 1 & $7 \cdot 5$ & 1 & 6 & 14 & $3-5$ & 1 & 6 \\
\hline- & - & - & - & - & - & - & - & - & - & - & - \\
\hline- & - & - & - & - & - & - & - & - & - & - & - \\
\hline- & - & - & - & - & - & - & - & - & - & - & - \\
\hline- & - & - & - & - & - & - & - & - & - & - & - \\
\hline- & - & - & - & - & - & 1 & 4 & - & - & - & - \\
\hline- & - & - & - & - & - & 1 & $2 \cdot 7$ & - & - & - & - \\
\hline- & - & - & $5-6$ & - & - & - & - & - & - & - & - \\
\hline 9 & $6 \cdot 3-9 \cdot 64$ & - & - & - & - & - & - & - & - & - & - \\
\hline- & - & - & - & 1 & $7 \cdot 98$ & - & - & 2 & ca. 6 & - & - \\
\hline 82 & $?$ & - & - & 4 & $5 \cdot 95-8$ & - & - & 80 & $4-7 \cdot 05$ & - & - \\
\hline- & - & - & - & - & - & - & - & 1 & $3 \cdot 5$ & - & - \\
\hline 55 & $5 \cdot 25-12 \cdot 25$ & - & - & 9 & $6 \cdot 2-11 \cdot 9$ & - & - & 15 & $3 \cdot 8-6 \cdot 9$ & - & - \\
\hline 1 & $7 \cdot 7$ & - & - & 14 & $5 \cdot 6-11 \cdot 27$ & - & - & 16 & $3 \cdot 2-6 \cdot 5$ & - & - \\
\hline- & - & - & - & 1 & 8 & - & - & - & - & - & - \\
\hline- & - & - & - & 1 & $8 \cdot 8-15$ & - & - & 19 & $5 \cdot 8-8 \cdot 5$ & - & - \\
\hline- & - & - & - & - & - & - & - & - & - & - & - \\
\hline 8 & $4 \cdot 5-7 \cdot 7$ & - & - & 1 & $9 \cdot 8$ & - & - & 1 & 6.37 ca. & - & - \\
\hline 9 & $5 \cdot 5-8$ & 1 & $10 \cdot 8$ & - & - & - & - & 3 & $6 \cdot 6-6 \cdot 9$ & - & - \\
\hline 1 & $9 \cdot 8$ & - & - & - & - & - & - & - & - & - & - \\
\hline 9 & $7 \cdot 35-10 \cdot 35$ & 2 & $11 \cdot 06-11 \cdot 69$ & - & - & - & - & - & - & - & - \\
\hline 11 & $6 \cdot 4-10$ & 10 & $8-15$ & - & - & - & - & 13 & $5 \cdot 6-14$ & - & - \\
\hline 14 & $6 \cdot 3-9 \cdot 8$ & - & - & 1 & $\mathrm{z}$ & - & - & - & - & - & - \\
\hline 12 & $5-9$ & - & - & 12 & $6-13 \cdot 5$ & - & - & 13 & $4 \cdot 6-7 \cdot 3$ & - & - \\
\hline- & - & - & - & 6 & $6 \cdot 86-10 \cdot 5$ & - & - & 23 & $4 \cdot 7-7 \cdot 3$ & - & - \\
\hline- & - & - & - & - & - & - & - & - & - & - & - \\
\hline- & - & - & - & - & - & - & - & 3 & $5 \cdot 7-7 \cdot 35$ & - & - \\
\hline 12 & $4 \cdot 9-6 \cdot 5$ & - & - & - & - & - & - & 11 & $3 \cdot 8-7$ & - & - \\
\hline- & - & 1 & 6 & 5 & $10-17$ & - & - & - & - & - & - \\
\hline 8 & $4 \cdot 5-8 \cdot 5$ & - & - & 1 & $8 \cdot 4$ & - & - & 8 & $5 \cdot 2-6 \cdot 3$ & - & - \\
\hline 30 & $5-9 \cdot 5$ & - & - & 1 & 14 & 1 & $4 \cdot 9$ & 50 & $3 \cdot 8-9 \cdot 8$ & - & - \\
\hline 2 & $6 \cdot 65-6 \cdot 9$ & - & - & 1 & 10 & - & - & 16 & $4 \cdot 2-9 \cdot 1$ & - & - \\
\hline 1 & $9 \cdot 6$ & 2 & $4 \cdot 6-4 \cdot 75$ & - & - & - & - & - & $\overline{-}$ & 1 & $9 \cdot 6$ \\
\hline- & - & - & - & - & - & - & - & 2 & $7-7 \cdot 7$ & - & - \\
\hline- & - & - & - & - & - & - & - & - & - & - & - \\
\hline - & - & - & - & - & - & - & - & 24 & $4 \cdot 2-6 \cdot 4$ & - & - \\
\hline - & - & - & - & - & - & - & - & 1 & $5 \cdot 8$ & - & - \\
\hline - & - & - & - & - & - & - & - & 2 & $5-6 \cdot 8$ & - & - \\
\hline $\bar{\pi}$ & $\overline{-}$ & - & - & - & - & - & - & - & - & - & - \\
\hline 5 & $6 \cdot 5-11$ & - & - & - & - & - & - & 31 & $5-8 \cdot 6$ & - & - \\
\hline 2 & $6 \cdot 58-8$ & - & - & - & - & 1 & 8.05 & 13 & $5 \cdot 6-7 \cdot 7$ & 1 & $17 \cdot 5$ \\
\hline- & - & - & - & - & - & $\overline{0}$ & - & 7 & $4 \cdot 8-7 \cdot 6$ & - & - \\
\hline- & - & - & - & $\overline{1}$ & $\overline{0}$ & 2 & $4 \cdot 9$ & $\overline{3}$ & - & - & - \\
\hline- & - & $\overline{10}$ & $7-\overline{-15} \cdot 5$ & 1 & 9 & $\overline{1}$ & $\overline{1}$ & 11 & $5-7$ & - & - \\
\hline 1 & $8 \cdot 5$ & 19 & $\begin{array}{c}7-15 \cdot 5 \\
-\end{array}$ & $\begin{array}{l}2 \\
3\end{array}$ & $8 \cdot 5-15$ & 1 & 4 & 1 & $4 \cdot 9$ & 1 & $6 \cdot 16$ \\
\hline - & - & $\overline{4}$ & $\bar{z}$ & 3 & $\begin{array}{c}7-17 \\
-\end{array}$ & $\begin{array}{c}2 \\
40\end{array}$ & $\begin{array}{c}6 \cdot 3 \\
5-7 \cdot 5\end{array}$ & 7 & $5 \cdot 5-6 \cdot 5$ & 2 & ca. $7 \cdot 6$ \\
\hline- & - & 4 & z & $\overline{1}$ & $\overline{7 \cdot 2}$ & $\begin{array}{c}40 \\
1\end{array}$ & $\begin{array}{c}5-7 \cdot 5 \\
6 \cdot 5\end{array}$ & 1 & $\mathrm{z}$ & 1 & $6 \cdot 5$ \\
\hline - & - & - & - & $\frac{1}{-}$ & - & $\begin{array}{l}1 \\
2\end{array}$ & $\cdot 6-6 \cdot 6$ & 1 & $5 \cdot 39$ & - & - \\
\hline - & - & - & - & - & - & $\begin{array}{l}2 \\
3\end{array}$ & $\begin{array}{l}5 \cdot 0-0 \cdot 0 \\
\text { ca. } 7 \cdot 5\end{array}$ & $\overline{-}$ & - & 2 & $9-14$ \\
\hline - & $\overline{-}$ & - & - & - & - & 7 & ca. 9 & - & - & $\frac{2}{-}$ & ca. 7 \\
\hline
\end{tabular}


TABLE XXV.-

\begin{tabular}{|c|c|c|c|c|c|c|c|c|c|c|}
\hline \multirow[b]{2}{*}{ No. Haul, } & \multicolumn{2}{|c|}{ Clupea sp. } & \multicolumn{2}{|c|}{ Ammodytes sp. } & \multicolumn{2}{|c|}{ Labrus bergylta. } & \multicolumn{2}{|c|}{$\begin{array}{l}\text { Ctenolabrus } \\
\text { rupestris. }\end{array}$} & \multicolumn{2}{|c|}{ Arnoglossus sp. } \\
\hline & No. & & No. & Size. & No. & Size. & & & & Size. \\
\hline XLIV. A & 1 & 20 & 27 & ca. 20 & - & - & - & - & 5 & $4 \cdot 5-14 \cdot 5$ \\
\hline XLV. A & - & - & 6 & $11-15$ & - & - & - & - & 1 & 15 \\
\hline XLVI. A & 1 & 23 & 2 & $7-26 \cdot 5$ & - & - & 7 & $4 \cdot 5-6 \cdot 5$ & 22 & $4 \cdot 5-14 \cdot 5$ \\
\hline XLVII. A & 1 & 25 & - & - & - & - & - & - & - & - \\
\hline XLVIII. A & - & - & 1 & 7 & 20 & $3 \cdot 4-7 \cdot 5$ & 2 & $7 \cdot 5-8$ & - & - \\
\hline XLIX. A & 1 & 14 & 20 & $6 \cdot 5-16.5$ & - & - & - & - & 21 & $3 \cdot 5-20 \cdot 5$ \\
\hline L. A & - & - & - & - & - & - & - & - & 28 & $7-21 \cdot 5$ \\
\hline LI. A & - & - & - & - & - & - & - & - & 5 & $6 \cdot 5-12 \cdot 5$ \\
\hline LII. A & 2 & 25 & 1 & 7 & 1 & $5 \cdot 5$ & 1 & 6 & - & - \\
\hline LIII. A & 2 & $14-20$ & 2 & $10-21$ & - & - & - & - & 7 & $4 \cdot 5-23 \cdot 5$ \\
\hline LIV. A & 15 & $12-22$ & 8 & $6 \cdot 5-13$ & 3 & $6 \cdot 5-8$ & - & - & 25 & $4-15$ \\
\hline LV. A & 20 & $12-17$ & 3 & $7-16$ & - & - & - & - & 33 & $4-14$ \\
\hline LVI. A & 4 & $11-16$ & - & - & - & - & - & - & 20 & $5 \cdot 5-12$ \\
\hline LVII. A & 4 & $13 \cdot 5-16 \cdot 5$ & 2 & $10 \cdot 5-16$ & - & - & - & - & 9 & $5-8 \cdot 5$ \\
\hline LVIII. A & 17 & $9 \cdot 5-21$ & - & - & 1 & $5 \cdot 49$ & - & - & 6 & $5-13 \cdot 5$ \\
\hline LIX. A & 1 & 36 & - & - & - & - & - & - & - & - \\
\hline LX. A & - & - & 2 & $9-14$ & - & - & 2 & $5 \cdot 5-6$ & 14 & $7-21 \cdot 5$ \\
\hline LXI. A & - & - & 7 & $7 \cdot 5-23 \cdot 5$ & 1 & $5 \cdot 25$ & 1 & 6 & 31 & $4 \cdot 5-14.5$ \\
\hline LXII. A & - & - & 12 & $4 \cdot 5-12$ & I & $5 \cdot 2$ & - & - & 14 & $5 \cdot 5-17$ \\
\hline LXIII. A & 1 & 11 & 6 & $6-16 \cdot 5$ & - & - & - & - & 13 & $5-12$ \\
\hline LXIV. A & - & - & 14 & $10-19$ & - & - & - & - & 2 & $5-7 \cdot 5$ \\
\hline LXV. A & - & - & 13 & $7-15$ & 1 & $6 \cdot 16$ & - & - & 3 & $\mathrm{z}$ \\
\hline LXVI. A & - & - & 1 & 14.5 & - & - & - & - & 1 & 8.5 \\
\hline LXVII. A & - & - & - & - & - & - & - & - & 4 & $9-19 \cdot 5$ \\
\hline LXVIII. A & - & - & 1 & 7 & - & - & - & - & 7 & $6 \cdot 5-10$ \\
\hline X. A & - & - & 2 & $13-17 \cdot 5$ & - & - & - & - & 4 & $5-15$ \\
\hline LXX. A & - & - & - & - & 2 & 8 & - & - & 2 & $6-6 \cdot 5$ \\
\hline LXXI. A & - & - & - & - & - & - & - & - & - & - \\
\hline LXXII. A & 1 & $24 \cdot 5$ & - & - & - & - & - & - & - & - \\
\hline LXXIII. A & - & - & - & - & - & - & - & - & 2 & $12-16$ \\
\hline LXXIV. A & - & - & - & - & - & - & - & - & 1 & 11 \\
\hline LXXV. A & - & - & 2 & $8 \cdot 5-10 \cdot 5$ & - & - & 1 & $7 \cdot 5$ & 4 & $7 \cdot 5-11$ \\
\hline LXXVI. A & 1 & 23 & - & - & 1 & 4 & - & - & 8 & $6-21$ \\
\hline LXXVII. A & - & - & 3 & $11-17$ & - & - & - & - & 5 & $8-18$ \\
\hline LXXVIII. A & - & - & 5 & $6 \cdot 5-21$ & - & - & - & - & 6 & $7 \cdot 5-18$ \\
\hline LXXIX. A & 1 & $\mathrm{z}$ & 1 & 6 & - & - & - & - & 4 & $10 \cdot 5-15$ \\
\hline LXXX. A & - & - & 2 & 14 & 4 & $6 \cdot 5-8$ & - & - & - & - \\
\hline $\mathrm{A}$ & - & - & - & - & - & - & - & - & - & - \\
\hline LXXXII. A & 1 & 23 & - & - & - & - & - & - & 1 & 6 \\
\hline LXXXIII. A & - & - & 1 & 9 & - & - & - & - & 1 & 20 \\
\hline LXXXIV. A & 1 & $24 \cdot 5$ & - & - & - & - & - & - & - & - \\
\hline XXXV. A & - & - & - & $=$ & - & - & - & - & - & - \\
\hline VI. A & - & - & 1 & $6 \cdot 5$ & - & - & - & - & - & - \\
\hline III. A & - & - & - & - & - & - & - & - & - & - \\
\hline LXXXVIII. A & - & - & - & - & - & - & - & - & - & - \\
\hline LXXXIX. A & 1 & 25 & - & - & - & - & - & - & - & - \\
\hline XC. A & - & - & - & - & 1 & 7 & - & - & - & - \\
\hline XCI. A & - & - & - & - & - & - & - & - & - & - \\
\hline XCII. A & 2 & $21-23$ & 12 & $10 \cdot 5-10 \cdot 5$ & - & - & - & - & 7 & $7 \cdot 5-20$ \\
\hline XCIII. A & - & - & 2 & $7 \cdot 5-1$ & - & - & - & - & 2 & $13 \cdot 5-20 \cdot 5$ \\
\hline XCIV. A & 1 & 14 & 18 & $5-1$ & - & - & - & - & 2 & $11-13 \cdot 5$ \\
\hline XCV. A & - & - & 55 & $6 \cdot 5-1$ & - & - & - & - & 13 & $4-16.5$ \\
\hline XCVI. A & - & - & 40 & $8-25$ & - & - & - & - & 10 & $8-20$ \\
\hline XCVII. A & - & - & 42 & $7 \cdot 5-15 \cdot 5$ & - & - & - & - & 7 & $6-18$ \\
\hline XCVIII. A & - & - & 3 & 9 & - & - & - & - & 8 & ca. 5 \\
\hline XCIX. A & - & - & 56 & $11 \cdot 5-22$ & - & - & 1 & 7 & 22 & $8-28.5$ \\
\hline C. A & 5 & $20-20 \cdot 5$ & 20 & $6-16$. & - & - & - & - & 60 & - \\
\hline CI. A & - & - & 17 & $8 \cdot 5-16 \cdot 5$ & - & - & - & - & 12 & $4 \cdot 5-20$ \\
\hline CII. A & 4 & $15 \cdot 5-17$ & 32 & $7-18$ & - & - & - & - & 69 & $4-22$ \\
\hline CIII. A & i & $19 \cdot 5$ & 31 & $8 \cdot 5-14.5$ & - & - & - & - & 13 & $4-19 \cdot 5$ \\
\hline
\end{tabular}


Continued.

\begin{tabular}{|c|c|c|c|c|c|c|c|c|c|c|c|}
\hline \multicolumn{2}{|c|}{$\begin{array}{l}\text { Scophthalmus } \\
\text { norvegicus. }\end{array}$} & \multicolumn{2}{|c|}{ Gobius sp. } & \multicolumn{2}{|c|}{ Trigla sp. } & \multicolumn{2}{|c|}{$\begin{array}{l}\text { Trachinus } \\
\text { vipera. }\end{array}$} & \multicolumn{2}{|c|}{$\begin{array}{c}\text { Callionymus } \\
\text { lyra. }\end{array}$} & \multicolumn{2}{|c|}{ Blennius sp. } \\
\hline No. & Size. & No. & Size. & No. & Size. & No. & Size. & No. & Size. & No. & Size. \\
\hline - & - & - & - & - & - & 17 & $4 \cdot 5-9$ & 9 & $5 \cdot 5-8$ & - & - \\
\hline- & - & - & - & - & - & - & - & 1 & 7 & - & - \\
\hline- & - & - & - & 3 & $7-12$ & 112 & $3 \cdot 5-8$ & 28 & $4-8 \cdot 5$ & 4 & $5 \cdot 6-7 \cdot 5$ \\
\hline- & - & - & - & - & - & - & - & - & - & - & - \\
\hline- & - & - & - & - & - & 1 & $4 \cdot 8$ & - & - & 1 & 8.5 \\
\hline- & - & - & - & 3 & $7 \cdot 5-13 \cdot 5$ & 17 & $3 \cdot 5-5 \cdot 5$ & 17 & $4 \cdot 5-8$ & 3 & $5 \cdot 5-8$ \\
\hline- & - & - & - & - & - & - & - & 1 & $\mathrm{z}$ & - & - \\
\hline- & - & - & - & 1 & 9 & - & - & - & - & - & - \\
\hline- & - & - & - & - & - & 1 & 4 & - & - & 1 & $\mathrm{z}$ \\
\hline- & - & 8 & $4 \cdot 5-16 \cdot 5$ & - & - & 3 & $4 \cdot 5-6 \cdot 5$ & 5 & $3-8$ & 1 & 6 \\
\hline- & - & 7 & $4 \cdot 5-13$ & - & - & 13 & $4-7 \cdot 5$ & 29 & $3-11$ & 1 & $4 \cdot 5$ \\
\hline- & - & 3 & ca. $11 \cdot 5$ & 1 & 7 & 10 & $4-7 \cdot 5$ & 8 & $4-7$ & - & - \\
\hline- & - & 1 & $3 \cdot 5$ & 1 & $8 \cdot 5$ & 4 & $3-5 \cdot 5$ & 4 & $3 \cdot 5-5$ & 2 & ca. 6 \\
\hline- & - & 5 & $6-13$ & - & - & 2 & $4-5 \cdot 5$ & 4 & $4-10$ & - & - \\
\hline- & - & 1 & 10 & 2 & $9-16.5$ & 5 & $4-6 \cdot 5$ & 4 & $5-13$ & 1 & 10 \\
\hline- & - & 1 & 31 & - & - & 1 & 18 & - & - & 1 & 7 \\
\hline- & - & 3 & $6-7$ & - & - & 27 & $3 \cdot 5-9$ & - & - & 2 & $5 \cdot 5-7 \cdot 5$ \\
\hline- & - & - & - & - & - & 25 & $3-11 \cdot 25$ & - & - & - & - \\
\hline- & - & - & - & - & - & 4 & $3 \cdot 75-5$ & 7 & $3 \cdot 7-4 \cdot 6$ & 1 & $6 \cdot 03$ \\
\hline- & - & - & - & 1 & $4 \cdot 69$ & 3 & $4 \cdot 4-5 \cdot 1$ & 13 & $3 \cdot 0-6 \cdot 7$ & - & - \\
\hline- & - & - & - & - & - & 1 & 7 & 10 & $2 \cdot 75-$ & - & - \\
\hline- & - & - & - & - & - & 2 & $3 \cdot 6$ & 6 & $3 \cdot 68-7 \cdot 2$ & - & - \\
\hline- & - & - & - & - & - & 1 & $5 \cdot 4$ & 2 & $5 \cdot 3-6 \cdot 7$ & - & - \\
\hline- & - & - & - & - & - & 2 & $4 \cdot 5-5 \cdot 6$ & 3 & $3 \cdot 6-6 \cdot 7$ & 1 & $4 \cdot 8$ \\
\hline- & - & - & - & 1 & $5 \cdot 36$ & 6 & $4 \cdot 5-8 \cdot 5$ & 1 & $5 \cdot 5$ & 1 & $5 \cdot 3$ \\
\hline- & - & 1 & 7 & - & - & 2 & $4 \cdot 35$ & 1 & $4 \cdot 5$ & 1 & $6 \cdot 03$ \\
\hline- & - & - & - & - & - & 2 & $5 \cdot 5-8 \cdot 5$ & 5 & $3 \cdot 8-5 \cdot 7$ & 1 & 13 \\
\hline- & - & - & - & - & - & - & - & - & - & - & - \\
\hline- & - & - & - & - & - & 3 & $\mathrm{z}$ & 10 & $5 \cdot 6-8 \cdot 7$ & - & - \\
\hline- & - & - & - & - & - & - & - & - & - & - & - \\
\hline- & - & - & - & - & - & - & - & 3 & $5 \cdot 3-5 \cdot 6$ & 1 & 11 \\
\hline- & - & - & - & - & - & - & - & 2 & $4 \cdot 6-5 \cdot 5$ & 4 & $6 \cdot 5-8$ \\
\hline- & - & - & - & 3 & $4 \cdot 5-11$ & 7 & $5-6$ & 3 & $4-6$ & 1 & 4 \\
\hline- & - & 1 & $\mathrm{z}$ & 1 & $9 \cdot 5$ & 1 & $4 \cdot 35$ & 1 & $6 \cdot 03$ & - & - \\
\hline- & - & - & - & - & - & 1 & 13.5 & - & - & - & - \\
\hline- & - & 3 & $8 \cdot 5-11$ & 6 & $7-10$ & - & - & 3 & $5 \cdot 2-8 \cdot 8$ & - & - \\
\hline- & - & - & - & - & - & 4 & $6-7$ & - & - & - & - \\
\hline- & - & 2 & $3 \cdot 5-4$ & 1 & $z$ & 2 & $4-9 \cdot 5$ & - & - & 4 & $4 \cdot 5-6 \cdot 5$ \\
\hline- & - & - & - & 1 & 8 & 1 & $5 \cdot 5$ & - & - & 1 & 10 \\
\hline- & - & - & - & 2 & $6-6 \cdot 5$ & 1 & 4 & - & - & 2 & $5-7$ \\
\hline - & - & - & - & - & - & 1 & $6 \cdot 5$ & - & - & - & - \\
\hline- & - & 1 & $5 \cdot 06$ & - & - & - & - & 1 & 6 & 1 & $5 \cdot 5$ \\
\hline- & - & 1 & $4 \cdot 02$ & - & - & 1 & $4 \cdot 4$ & - & . - & 3 & ca. 8 \\
\hline- & - & 1 & $2 \cdot 8$ & - & - & 4 & $5-10$ & - & - & - & - \\
\hline- & - & 2 & $11-18$ & - & - & - & - & - & - & 1 & $12 \cdot 5$ \\
\hline- & - & - & - & 1 & $8 \cdot 5$ & - & $\overline{0}$ & - & - & - & - \\
\hline- & - & 2 & $3-6$ & - & - & 1 & 8 & 1 & $6 \cdot 5$ & 1 & $18 \cdot 5$ \\
\hline - & - & - & - & - & - & 1 & $6 \cdot 5$ & - & - & 1 & 7 \\
\hline- & - & 2 & $9-12$ & 4 & $5-15$ & 7 & $3-9$ & 1 & 8 & 2 & $9-13$ \\
\hline- & - & 1 & $6 \cdot 5$ & 4 & $5 \cdot 5-20$ & - & - & 1 & $7 \cdot 5$ & 3 & $5-6$ \\
\hline - & - & - & - & 1 & $10 \cdot 5$ & 1 & $5 \cdot 5$ & 4 & $4 \cdot 5-8 \cdot 5$ & - & - \\
\hline - & - & $\overline{8}$ & - & 2 & $5-16 \cdot 5$ & 4 & ca. $4 \cdot 5$ & 10 & $3-6$ & 3 & $4 \cdot 5-5 \cdot 5$ \\
\hline- & - & 2 & $6-8$ & 4 & $7 \cdot 5-13 \cdot 5$ & 1 & $\mathrm{z}$ & 11 & $4 \cdot 5-9$ & - & - \\
\hline- & - & 1 & 6 & 2 & ca. 8 & 1 & $8 \cdot 75$ & 29 & $3 \cdot 5-8 \cdot 5$ & - & - \\
\hline- & - & - & - & 2 & $13 \cdot 5-15 \cdot 5$ & 4 & $4 \cdot 5-5$ & 4 & $4 \cdot 5-7$ & - & - \\
\hline- & - & - & - & 3 & $8-9$ & 17 & $4-9 \cdot 5$ & 7 & 4-8 & - & - \\
\hline- & - & 4 & $2 \cdot 3-56$ & 9 & $4 \cdot 2-22$ & 20 & $4-5$ & 11 & 3-8 & 2 & $5 \cdot 2-6 \cdot 7$ \\
\hline- & - & 2 & 3-4 & 4 & ca. 6 & 10 & $3 \cdot 5-6$ & 8 & $3 \cdot 7-5 \cdot 6$ & 1 & $5 \cdot 2$ \\
\hline- & - & 3 & ca. $4 \cdot 5$ & 10 & $6-18$ & 23 & $3 \cdot 5-6 \cdot 9$ & 18 & $4-5 \cdot 4$ & 7 & $4-10 \cdot 5$ \\
\hline- & - & - & - & - & - & 3 & $2 \cdot 68-5 \cdot 2$ & 1 & $5 \cdot 3$ & - & - \\
\hline
\end{tabular}


TABLE XXV.-

\begin{tabular}{|c|c|c|c|c|c|c|c|c|c|c|}
\hline \multirow{3}{*}{$\begin{array}{l}\text { No. of Haul, } \\
\text { CIV. A }\end{array}$} & \multicolumn{2}{|c|}{ Clupea sp. } & \multicolumn{2}{|c|}{ Ammodytes sp. } & \multicolumn{2}{|c|}{ Labrus bergylta. } & \multicolumn{2}{|c|}{$\begin{array}{l}\text { Ctenolabrus } \\
\text { rupestris. }\end{array}$} & \multirow{2}{*}{\multicolumn{2}{|c|}{ Arnoglossus sp. }} \\
\hline & & & No. & Size. & No. & Size. & No. & Size. & & \\
\hline & 4 & $16 \cdot 5-18 \cdot 5$ & 20 & $5-16 \cdot 5$ & - & - & - & - & 7 & $4 \cdot 5-18$ \\
\hline & 2 & $19 \cdot 5-20$ & 20 & $6-17$ & - & - & - & - & 21 & $4-18 \cdot 5$ \\
\hline CVI. A & $\overline{1}$ & 20.5 & 6 & $11 \cdot 5-18$ & - & - & - & - & 14 & $5-21 \cdot 5$ \\
\hline CVII. A & - & - & - & - & - & - & - & - & - & \\
\hline CVIII. A & - & - & - & - & - & - & - & - & 2 & $5-11$ \\
\hline CIX. A & - & - & - & - & $\overline{-}$ & - & - & $\overline{-}$ & 1 & $\mathrm{z}$ \\
\hline CX. A & - & - & - & - & - & - & - & - & - & \\
\hline CXI. A & 1 & $9 \cdot 5$ & - & - & - & - & - & - & 4 & $5-7 \cdot 5$ \\
\hline CXII. A & - & - & - & - & - & - & - & - & - & - \\
\hline CXIII. A & - & - & - & - & - & - & - & - & 3 & $4 \cdot 5-5$ \\
\hline CXIV. A & - & - & - & - & - & - & - & - & 1 & 6 \\
\hline CXV. A & - & - & 1 & 7 & - & - & - & - & 4 & $4 \cdot 5-10$ \\
\hline CXVI. A & - & - & - & - & - & - & - & - & 33 & $4-9 \cdot 5$ \\
\hline CXVII. A & - & _- & - & - & - & - & - & - & 21 & $4-21$ \\
\hline CXVIII. A & - & - & - & - & - & - & - & - & 13 & $4-19$ \\
\hline CXIX. A & - & - & - & - & - & - & - & - & 8 & $6 \cdot 5-19$ \\
\hline CXX. A & - & - & - & - & - & - & - & - & 3 & $4 \cdot 4-11 \cdot 5$ \\
\hline CXXI. A & - & - & - & - & - & - & - & - & 4 & $6-14$ \\
\hline CXXII. A & - & - & 1 & $5 \cdot 5$ & - & - & - & - & 11 & $5-7 \cdot 5$ \\
\hline CXXIII. A & - & - & - & - & - & - & - & - & 8 & $4 \cdot 5-9$ \\
\hline CXXIV. A & $=$ & - & - & - & - & - & - & - & 25 & $4 \cdot 8-9 \cdot 5$ \\
\hline CXXV. A & 7 & $4 \cdot 5-5 \cdot 5$ & - & - & - & - & - & - & 1 & 4 \\
\hline CXXVI. A & - & - & - & - & - & - & - & - & 1 & 6 \\
\hline CXXVII. A & - & - & - & - & - & - & - & - & - & - \\
\hline CXXVIII. A & 2 & $3 \cdot 4$ & - & - & - & - & - & - & - & - \\
\hline CXXIX. A & - & - & - & - & - & - & - & - & - & - \\
\hline CXXX. A & - & - & - & - & - & - & - & - & - & - \\
\hline CXXXI. A & - & - & - & - & - & - & - & - & 6 & $4 \cdot 5-8$ \\
\hline CXXXII. A & - & - & - & - & - & - & - & - & 8 & $5 \cdot 5-16$ \\
\hline CXXXII. A & - & - & - & - & - & - & - & - & 5 & $4 \cdot 5-7$ \\
\hline CXXXIV. A & - & - & - & - & - & - & - & - & 20 & $4 \cdot 5-11$ \\
\hline CXXXV.A & - & - & - & - & - & - & - & - & 1 & $7 \cdot 5$ \\
\hline CXXXVI. A & - & - & - & - & - & - & - & - & 4 & $4 \cdot 5-5$ \\
\hline CXXXVII. A & - & - & - & - & - & - & - & - & ? & $4 \cdot 8-6 \cdot 5$ \\
\hline CXXXVIII. A & - & - & - & - & - & - & - & - & 5 & $6-8 \cdot 5$ \\
\hline CXXXIX. A & - & - & - & - & - & - & - & - & 10 & $6 \cdot 5-8$ \\
\hline CXL. A & - & - & - & - & - & - & - & - & 7 & $5-9 \cdot 75$ \\
\hline CXLI. A & - & - & - & - & - & - & - & - & 11 & $5 \cdot 5-12$ \\
\hline CXLII. A & - & - & - & - & - & - & - & - & 23 & $4 \cdot 5-10$ \\
\hline CXLIII. A & - & - & 1 & $6 \cdot 5$ & - & - & - & - & 4 & $4 \cdot 25-6 \cdot 25$ \\
\hline CXLIV. A & - & - & - & - & - & - & - & - & 8 & $6-8$ \\
\hline CXLV: A & - & - & - & - & - & - & - & - & 3 & $5 \cdot 36-5 \cdot 67$ \\
\hline CXLVI. A & 2 & $5-5 \cdot 6$ & - & - & - & - & - & - & - & - \\
\hline CXLVII. A & 1 & 5 & - & - & - & - & - & - & - & - \\
\hline CXLVIII. A & 1 & $4 \cdot 5$ & - & - & - & - & - & - & - & - \\
\hline CXLIX. A & 2 & $4 \cdot 75-5$ & - & - & - & - & - & - & - & $\overline{-}$ \\
\hline CL. A & 4 & 5 & - & - & - & - & - & - & - & - \\
\hline CLI. A & - & - & - & - & - & - & - & - & 1 & $6 \cdot 25$ \\
\hline CLII. A & 1 & $6 \cdot 25$ & 1 & $11 \cdot 25$ & - & - & - & - & 5 & $7-10$ \\
\hline CLIII. A & - & - & - & - & - & - & - & - & 1 & \\
\hline CLIV. A & - & - & - & - & - & - & - & - & 4 & $10 \cdot 25-18$ \\
\hline CLV. A & 2 & $5 \cdot 25-13$ & 1 & 20 & - & - & - & - & 10 & $9 \cdot 5-17$ \\
\hline CLVI. A & 2 & $3 \cdot 5-5$ & 2 & $9 \cdot 5-10 \cdot 5$ & - & - & - & - & 49 & $4 \cdot 5-18 \cdot 5$ \\
\hline CLVII. A & 1 & $5 \cdot 25$ & - & - & - & - & - & - & - & - \\
\hline CLVIII. A & 16 & $4-12$ & - & - & - & - & - & - & 3 & $3 \cdot 5-31$ \\
\hline CLIX. A & 2 & $3 \cdot 5-8 \cdot 5$ & - & - & - & - & - & - & 9 & $8 \cdot 5-16 \cdot 5$ \\
\hline CLX. A & - & - & - & - & - & - & - & - & 9 & $6 \cdot 5-15$ \\
\hline CLXI. A & 3 & $4 \cdot 5-6$ & - & - & - & - & - & - & 6 & ca. $3-16$ \\
\hline CLXII. A & 1 & $\mathrm{z}$ & - & - & - & - & - & - & 7 & $\mathrm{z}$ \\
\hline CLXIII. A & 3 & $6-8 \cdot 5$ & - & - & - & - & - & - & 3 & z \\
\hline
\end{tabular}


Continued.

\begin{tabular}{|c|c|c|c|c|c|c|c|c|c|c|c|}
\hline \multicolumn{2}{|c|}{$\begin{array}{l}\text { Seophthalmus } \\
\text { norvegicus. }\end{array}$} & \multicolumn{2}{|c|}{ Gobius sp. } & \multicolumn{2}{|c|}{ Trigla sp. } & \multicolumn{2}{|c|}{$\begin{array}{c}\text { Trachinus } \\
\text { vipera. }\end{array}$} & \multicolumn{2}{|c|}{$\begin{array}{c}\text { Callionymus } \\
\text { lyra. }\end{array}$} & \multicolumn{2}{|c|}{ Blennius sp. } \\
\hline No. & Size. & No. & Size. & No. & Size. & No. & Size. & No. & Size. & No. & Size. \\
\hline- & - & - & - & 2 & $5-10$ & 8 & 4-9 & 2 & $4 \cdot 3-7$ & 1 & $6 \cdot 2$ \\
\hline- & - & - & - & 1 & 15 & 36 & $3-7$ & 9 & $3-7$ & - & - \\
\hline - & - & 2 & $3 \cdot 68-3 \cdot 75$ & 1 & $6 \cdot 5$ & 6 & $\mathrm{z}$ & 4 & $3 \cdot 5-10$ & - & - \\
\hline - & - & - & - & - & - & - & - & - & - & 2 & \\
\hline- & - & - & - & 3 & $8-11$ & 1 & 4 & - & - & 3 & $5 \cdot 5-14 \cdot 5$ \\
\hline - & - & - & - & 2 & $8 \cdot 5-14$ & - & - & - & - & - & - \\
\hline - & - & - & - & 1 & $5 \cdot 5$ & - & - & - & - & - & - \\
\hline - & - & - & - & - & - & 1 & 4 & - & - & - & - \\
\hline - & - & 18 & $9-24.5$ & - & - & - & - & - & - & - & - \\
\hline - & - & 58 & $10-22$ & - & - & - & - & - & - & - & - \\
\hline - & - & - & - & - & - & - & - & 1 & 6 & - & - \\
\hline- & - & 2 & $3 \cdot 5-5 \cdot 5$ & - & - & - & - & 2 & $5 \cdot 5-7 \cdot 5$ & - & - \\
\hline- & - & - & - & - & - & - & - & - & - & - & - \\
\hline - & - & 1 & $3 \cdot 5$ & - & - & - & - & - & - & - & - \\
\hline- & - & - & - & - & - & - & - & - & - & 1 & $6 \cdot 5$ \\
\hline - & - & - & - & - & - & 1 & 4 & - & - & - & - \\
\hline - & - & - & - & - & - & - & - & - & - & 1 & 7 \\
\hline - & - & 3 & $5-6 \cdot 5$ & - & - & - & - & 3 & 4-7 & - & - \\
\hline - & - & 3 & ca. 4.5 & 1 & $6 \cdot 5$ & - & - & 2 & $5-6$ & - & - \\
\hline- & - & - & - & 1 & 5 & - & - & 8 & $5-9$ & - & - \\
\hline - & - & 2 & $4 \cdot 5-7 \cdot 5$ & 3 & $3 \cdot 5-4 \cdot 5$ & 1 & 7 & 1 & 5.5 & - & - \\
\hline - & - & - & - & - & - & - & - & - & - & - & - \\
\hline- & - & - & - & - & - & - & - & - & - & - & - \\
\hline- & - & - & - & - & - & - & - & - & - & - & - \\
\hline - & - & - & - & - & - & - & $\overline{-}$ & - & - & - & - \\
\hline - & - & - & - & - & - & 2 & $3 \cdot 5-6$ & - & - & - & - \\
\hline - & - & - & - & $\overline{1}$ & $\overline{15}$ & - & - & - & - & - & - \\
\hline I & $\overline{-}$ & $\overline{-}$ & $\overline{-}$ & $\frac{1}{-}$ & 15 & $\overline{2}$ & $\overline{4 \cdot 5}$ & $\overline{-}$ & $\bar{z}$ & $\overline{1}$ & $\overline{8.5}$ \\
\hline- & - & - & - & 2 & ca. $5 \cdot 5$ & - & - & - & - & - & - \\
\hline- & - & - & - & 1 & 6.5 & - & - & 2 & $5 \cdot 5-6$ & 1 & $7 \cdot 5$ \\
\hline- & - & - & - & - & - & - & - & - & - & - & - \\
\hline- & - & - & - & 1 & 6 & - & - & 1 & 7 & - & - \\
\hline 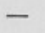 & - & - & - & - & - & - & - & - & - & 1 & $7 \cdot 25$ \\
\hline - & - & - & - & 2 & $5 \cdot 5-7 \cdot 5$ & - & - & - & - & - & - \\
\hline- & - & - & - & $\overline{9}$ & $\overline{7}$ & - & - & - & - & - & - \\
\hline - & - & $\bar{z}$ & $\overline{-}$ & $\begin{array}{l}2 \\
4\end{array}$ & $\begin{array}{l}5-7 \cdot 5 \\
6-10 \cdot 5\end{array}$ & $\overline{1}$ & $\overline{18}$ & $\overline{-}$ & $\bar{z}$ & $\overline{4}$ & $5-\overline{11} \cdot 5$ \\
\hline- & - & - & - & 1 & $9 \cdot 5$ & 2 & $3 \cdot 5-5 \cdot 5$ & 3 & $5 \cdot 5$ & i & $7 \cdot 5$ \\
\hline- & - & - & - & 4 & $5 \cdot 75-6 \cdot 5$ & - & - & - & - & - & - \\
\hline- & - & - & - & 3 & $6-1$ & - & - & - & - & 1 & 6 \\
\hline - & - & - & - & - & - & 1 & $\mathrm{z}$ & - & - & 1 & $13 \cdot 25$ \\
\hline- & - & - & - & - & - & - & - & - & - & - & - \\
\hline- & - & - & - & - & - & - & - & - & - & - & - \\
\hline- & - & - & - & - & - & - & - & - & - & - & - \\
\hline - & - & - & - & - & - & - & - & - & - & - & - \\
\hline - & - & - & - & - & - & - & - & - & - & - & - \\
\hline- & - & - & - & - & - & - & - & - & - & - & - \\
\hline - & - & - & - & - & - & - & - & - & - & - & - \\
\hline - & - & - & - & 1 & 6 & - & - & 1 & 7 & - & - \\
\hline - & - & - & - & 2 & $6 \cdot 5-7$ & - & - & - & - & - & - \\
\hline- & - & - & - & 1 & 13 & - & - & 1 & 5 & 1 & $\mathrm{z}$ \\
\hline - & - & - & - & 5 & $5 \cdot 25-7$ & 1 & $4 \cdot 25$ & - & - & 1 & 6.25 \\
\hline - & - & - & - & $\overline{1}$ & $\bar{\pi}$ & - & - & - & - & - & - \\
\hline - & - & $\overline{1}$ & $4 \cdot \overline{\cdot 25}$ & 1 & $\begin{array}{c}\mathrm{z} \\
5 \cdot 5-11 \cdot 5\end{array}$ & $\overline{1}$ & $\overline{7}$ & - & $\bar{z}$ & $\overline{1}$ & $\overline{8.5}$ \\
\hline ב & $\bar{z}$ & 1 & $\begin{array}{l}4 \cdot 25 \\
-\end{array}$ & 2 & $\begin{array}{c}5 \cdot 5-11 \cdot 5 \\
-\end{array}$ & 1 & $\underline{z}$ & $=$ & $\overline{-}$ & $\frac{1}{-}$ & $\begin{array}{c}8 \cdot 5 \\
-\end{array}$ \\
\hline- & - & - & $\overline{-}$ & $\overline{1}$ & $\overline{\mathrm{z}}$ & $\overline{-}$ & $=$ & - & - & - & - \\
\hline - & - & - & - & 9 & $6 \cdot 5-15$ & - & - & 2 & $\mathrm{z}$ & - & - \\
\hline- & - & - & - & 1 & $9 \cdot 5$ & 1 & 9 & - & - & - & \\
\hline
\end{tabular}


R. S. CLARK.

TABLE XXV.-

\begin{tabular}{|c|c|c|c|c|c|c|c|c|c|c|}
\hline \multirow[b]{2}{*}{ No. of Haul. } & \multicolumn{2}{|c|}{ Clupea sp. } & \multicolumn{2}{|c|}{ Ammodytes sp. } & \multicolumn{2}{|c|}{ Labrus bercylta, } & \multicolumn{2}{|c|}{$\begin{array}{l}\text { Ctenolabrus } \\
\text { rupestris. }\end{array}$} & \multicolumn{2}{|c|}{ Arnoglossus sp. } \\
\hline & No. & Size. & No. & Size. & No. & Size. & No. & Size. & No. & Size. \\
\hline CLXIV. A & 7 & $14-24$ & - & - & - & - & - & - & - & - \\
\hline CLXV. A & - & - & - & - & - & - & - & - & - & \\
\hline CLXVI. A & 20 & $5-8$ & - & - & - & - & - & - & - & - \\
\hline CLXVII. A & 2 & $5 \cdot 25$ & - & - & - & - & - & - & 2 & \\
\hline CLXVIII. A & 38 & $7 \cdot 5-8$ & - & - & - & - & - & - & - & - \\
\hline CLXIX. A & 24 & $5-9$ & - & - & - & - & - & - & 12 & $5-11$ \\
\hline CLXX. A & 5 & $6 \cdot 5-8$ & - & - & - & - & - & - & $?$ & - \\
\hline CLXXI. A & 38 & $6-15 \cdot 5$ & 1 & $17 \cdot 5$ & - & - & - & - & 145 & $5-20$ \\
\hline CLXXII. A & - & - & 2 & $19-24$ & - & - & - & - & 2 & $\mathrm{z}$ \\
\hline CLXXIII. A & - & - & 1 & 12 & - & - & - & - & 17 & $5-11 \cdot 5$ \\
\hline CLXXIV. A & 9 & $7-16$ & 1 & 12 & - & - & - & - & 24 & $4 \cdot 5-19$ \\
\hline CLXXV. A & 2 & $10-159$ & - & - & - & - & - & - & 2 & $17-19$ \\
\hline CLXXVI. A & 12 & $5-9 \cdot 5$ & - & - & - & - & - & - & 57 & $4-13 \cdot 5$ \\
\hline CLXXVII. A & 4 & $5-8 \cdot 5$ & - & - & - & - & - & - & 10 & $4 \cdot 5-11 \cdot 5$ \\
\hline CLXXVIII. A- & 7 & $6-11$ & - & - & - & - & - & - & 4 & $6-17$ \\
\hline CLXXIX. A & 5 & $7 \cdot 5-8$ & - & - & - & - & - & - & 24 & $5-18$ \\
\hline CLXXX. A & 22 & $5 \cdot 5-10$ & - & - & 1 & $4 \cdot 5$ & - & - & 2 & 4.5 \\
\hline CLXXXI. A & 3 & $7-13$ & - & - & - & - & - & - & 1 & 6 \\
\hline CLXXXII. A & 3 & $6-10$ & 1 & 22 & - & - & - & - & 7 & $9 \cdot 5-18$ \\
\hline CLXXXIII. A & 12 & $10 \cdot 5-12$ & - & - & - & - & - & - & 13 & $5-18 \cdot 5$ \\
\hline CLXXXIV. A & 12 & $8-13$ & - & - & - & - & - & - & - & - \\
\hline CLXXXV. A & 8 & $4.5-10.5$ & - & - & - & - & - & - & - & - \\
\hline CLXXXVI. A & 14 & $3 \cdot 5-11$ & - & - & - & - & - & - & 1 & 7 \\
\hline CLXXXVII. A & 4 & $7-10$ & - & - & - & - & - & - & - & - \\
\hline CLXXXVIII. A & 17 & $5-12$ & - & - & - & - & - & - & - & - \\
\hline CLXXXIX. A & 26 & $6-18$ & - & - & - & - & - & - & - & - \\
\hline CXC. A & 17 & $7 \cdot 5-17$ & - & - & - & - & - & - & 1 & $\mathrm{z}$ \\
\hline CXCI. A & 9 & $8 \cdot 5-12 \cdot 5$ & - & - & - & - & - & - & - & - \\
\hline CXCII. A & 228 & $5 \cdot 5-24$ & - & - & - & - & - & - & - & - \\
\hline CXCIII. A & 44 & $8-15 \cdot 25$ & - & - & - & - & - & - & - & - \\
\hline CXCIV. A & b02 & $7 \cdot 25-18 \cdot 5$ & - & - & - & - & - & - & - & - \\
\hline CXCV. A & 3 & $5-10.5$ & - & - & - & - & - & - & - & - \\
\hline CXCVI. A & 2 & $7-19 \cdot 5$ & - & - & - & - & - & - & - & - \\
\hline CXCVII. A & 37 & $7-16$ & - & - & - & - & - & - & - & - \\
\hline CXCVIII. A & 17 & $7 \cdot 5-21$ & - & - & - & - & - & - & - & - \\
\hline CXCIX. A & 22 & $5 \cdot 5-19$ & - & - & - & - & - & - & - & - \\
\hline CC. A & 4 & $11-16$ & - & - & - & - & - & - & - & - \\
\hline CCI. A & 2 & $10-11$ & - & 7 & - & - & - & - & - & - \\
\hline CCII. A & 3 & $8-13$ & - & - & - & - & - & - & - & - \\
\hline CCIII. A & 3 & $11-13$ & - & - & - & - & - & - & - & - \\
\hline CCIV. A & 4 & $10 \cdot 5-12.5$ & - & - & - & - & - & - & - & - \\
\hline CCV. A & 1 & 13 & - & - & - & - & - & - & - & - \\
\hline
\end{tabular}


Continued.

\begin{tabular}{|c|c|c|c|c|c|c|c|c|c|c|c|}
\hline \multicolumn{2}{|c|}{$\begin{array}{l}\text { Scophthalmus } \\
\text { norvegicus. }\end{array}$} & \multicolumn{2}{|c|}{ Gobius sp. } & \multicolumn{2}{|c|}{ Trigla sp. } & \multicolumn{2}{|c|}{$\begin{array}{l}\text { Trachinus } \\
\text { vipera. }\end{array}$} & \multicolumn{2}{|c|}{$\begin{array}{l}\text { Callionymus } \\
\text { lyra. }\end{array}$} & \multicolumn{2}{|c|}{ Blennius sp. } \\
\hline No. & Size. & No. & & No. & Size. & No. & Size. & No. & Size. & No. & Size. \\
\hline - & - & - & - & - & - & 1 & 7 & - & - & 1 & 21 \\
\hline - & - & 1 & 19 & - & - & - & - & - & - & - & - \\
\hline - & - & 1 & 6 & 2 & $6 \cdot 5-7 \cdot 5$ & 1 & $5 \cdot 5$ & - & - & - & - \\
\hline - & - & - & - & - & - & 1 & 7 & - & - & - & - \\
\hline - & - & - & - & 1 & $\mathrm{z}$ & - & - & - & - & - & - \\
\hline - & - & - & - & - & - & 1 & 5 & 1 & 5 & - & - \\
\hline - & - & - & - & - & - & - & - & 1 & 7 & - & - \\
\hline - & - & - & - & 2 & $8-28.5$ & 4 & $\mathrm{z}$ & 11 & $6-9 \cdot 5$ & 5 & $6 \cdot 5-8$ \\
\hline - & - & - & - & 2 & ca 18 & 4 & $5-6 \cdot 5$ & - & - & - & - \\
\hline - & - & - & - & 5 & $5-13$ & 1 & 6 & - & - & 1 & \\
\hline - & - & 1 & 6 & 3 & $5-12$ & 3 & $5-7 \cdot 5$ & 6 & $4 \cdot 5-10$ & 6 & $6 \cdot 5-12$ \\
\hline - & - & - & - & 1 & 14 & 1 & 9 & - & - & - & - \\
\hline - & - & 1 & $5 \cdot 5$ & - & - & 1 & $7 \cdot 5$ & 2 & $6-8$ & - & - \\
\hline - & - & - & - & 1 & $7 \cdot 5$ & 3 & $5 \cdot 5-7$ & 1 & 8 & - & - \\
\hline - & - & - & - & 2 & $6-8$ & $i$ & 7 & 1 & $7 \cdot 5$ & - & - \\
\hline - & - & 3 & $8-10$ & 3 & $5-7$ & 4 & $5-7$ & 6 & $5 \cdot 8$ & - & - \\
\hline - & - & - & - & - & - & - & - & - & - & - & - \\
\hline - & - & - & - & - & - & - & - & - & - & - & - \\
\hline- & - & - & - & 5 & $7 \cdot 5-14.5$ & 1 & 8 & $\overline{-}$ & $\overline{-}$ & $\overline{1}$ & $\overline{13}$ \\
\hline - & - & - & - & 8 & $7 \cdot 5-12 \cdot 5$ & - & - & - & - & - & - \\
\hline - & - & - & - & - & - & - & - & - & - & - & - \\
\hline - & - & 1 & 6 & - & - & - & - & - & - & - & - \\
\hline - & - & - & - & - & - & - & - & - & - & - & - \\
\hline - & - & - & - & - & - & - & - & - & - & - & - \\
\hline - & - & - & - & - & - & - & - & - & - & - & - \\
\hline - & - & - & - & - & - & - & - & - & - & - & - \\
\hline - & - & - & - & - & - & - & - & 1 & $5 \cdot 02$ & - & - \\
\hline - & - & - & - & - & - & - & - & - & - & - & - \\
\hline - & - & 27 & $11-29$ & - & - & - & - & - & - & - & - \\
\hline - & - & 147 & $21-32$ & - & - & - & - & - & - & - & - \\
\hline - & - & 15 & $23-33$ & - & - & - & - & - & - & - & - \\
\hline - & - & - & - & - & - & - & - & - & - & - & - \\
\hline - & - & - & - & - & - & - & - & - & - & - & - \\
\hline - & - & - & - & - & - & - & - & - & $-a$ & - & - \\
\hline - & - & - & - & - & - & - & - & - & - & - & - \\
\hline- & - & - & - & - & - & - & - & - & - & - & - \\
\hline $\bar{z}$ & $\overline{-}$ & $\overline{-}$ & $\bar{z}$ & $\bar{z}$ & $\bar{z}$ & $\bar{z}$ & $\overline{-}$ & $\bar{z}$ & $\overline{-}$ & $\overline{-}$ & $\overline{-}$ \\
\hline- & - & - & - & - & - & - & - & $\overline{-}$ & - & - & $\overline{-}$ \\
\hline- & - & - & - & - & - & - & - & - & - & - & - \\
\hline- & - & - & - & - & - & - & - & - & - & - & - \\
\hline- & - & - & - & - & - & - & - & - & - & - & - \\
\hline
\end{tabular}




\section{CONCLUDING REMARKS.}

The Tables of the occurrence of the various species with the number and size of individuals show that all those recorded spawn either in the immediate neighbourhood or at localities not far distant.

It may be of interest to note here the capture of the young stages of those adult forms which have approximately their most northern limit of distribution in Plymouth waters.*

The spawning period is definite for most of the species, though in cases such as the sprat and dragonet, it is prolonged indefinitely over a considerable part of the year. In closely related species of the same genus there may be wide variation in the length and time of spawning.

One of the most interesting problems suggested by the study of the distribution of pelagic larval and post-larval forms is the question of the nature of the causes which bring about the movements of young fishes from the inshore to the offshore waters and vice versa. There appears to be evidence in favour of the view that in some localities these movements are the result of inshore and offshore currents which are not constant and which seem to vary according to the prevailing winds. In narrow waters like the English Channel, the currents are doubtless modified by the general set of the main currents from the Atlantic, and by the contour of the coast-line. In addition, the tidal streams tend to make conditions more complex. The present records bring some evidence to bear on the matter. For example, pelagic larval and post-larval forms of Ctenolabrus rupestris, an inshore spawner, occurred in the waters south of the Eddystone rocks, while similar stages of Solea variegata, a deeper water type, were taken in comparatively shallow areas. The whole question is one of great interest and might well repay further investigation.

The vertical distribution of the young was found to vary considerably during day and night hauls. The latter yielded a much larger percentage of young forms from the surface layers.

Finally, incompleteness in the study of the Clupeida, Ammodytida, Triglida, Bothince, Gobiida, and Bleniid $x$ must be acknowledged, but these are now receiving special attention.

\section{REFERENCES.}

Ehrenbaum's two volumes on "Eier und Larven von Fischen" in the Nordisches Plankton series, Lief 4, 1905, and Lief 10, 1909, have been used extensively in the present work, both for the description of species and in the references to papers published previous to 1909.

* Since this paper went to press, the larvæ and post-larvæ of Serranus cabrilla have been identified from the 1913 material. I am indebted to Prof. Ehrenbaum for confirmation of my identification. 
Apstein, C. Die Verbreitung der pelagischen Fischeier und Larven in der Beltsee und den angrenzenden Meeresteilen. 1908-1909.

Wiss. Meeresunters. N.F. Abt. Kiel. Bd. 13. 1911.

Bowman, A. D. The Spawning Areas of Sand-eels in the North Sea. Fisheries, Scotland, Sci. Invest. 1913. III. (Jan., 1914.)

DAKIN, W. J. Notes on the biology of Fish Eggs and Larvæ. Internat. Revue Hydrobiol. Hydrog. III. 1910-11.

Damas, W. Contribution à la biologie des Gadides.

Proc. Verb Explor. Mer. X. 1909.

Danois, E. L. Étude systematique et biologique des Poissons de la Manche occidentale.

Thèses présentées à la Faculté des Sciences de Paris. Paris, 1913.

Ehrenbaum, E. Eier und Larven von Fischen.

Nordisches Plankton. Lief 4, 1905. Lief 10, 1909.

Ehrenbaum, E. Eier und Larven von Pleuronectiden der Nordsee und benachbarter gewässer.

Rapp. et Proc. Verb. XII. 1910.

Ehrenbaum, E., and Mrelck, W. Fangtabellen. Wiss. Meeresunters. N.F. Bd. IX. Abt. Helgoland. 1910.

Ehrenbaum, E. Die Plattfischlarven der Nordsee und benachbarter gewässer nach Zeit und Ort ihres Vorkommens.

Rapp. et Proc. Verb. XIII. 1911.

Ehrenbaum, E. The Mackerel and the Mackerel Fishery. Biological and Fishery-Statistical Report to the International Council for the investigation of the Sea.

Rapp. et Procès Verbaux des Réunions. Vol. XVIII. 1914.

FAGE, L. Recherches sur les stades pélagiques de quelques Teleostéens de

la Mer de Nice (parages de Monaco) et du Golfe de Lion.

Ann. de l'Institut Océanographique. Tome I, fasc. 1-7. 1909.

FAGE, L. Recherches sur la biologie de la Sardine (C. pilchardus Walb.).

Arch. Zool. Exp. et Gen. T. 52, fasc. 3. 1913.

Franz, V. Einige Versuche zur Biologie der Fischlarven.

Internat. Revue Hydrobiol. u. Hydrographie. II. 1909.

Franz, V. Untersuchungen über das spezifische genicht der planktonischen Fischeier.

Wiss. Meeresunters. Helgoland. IX. 1909-10.

HefFord, A. E. Notes on Teleostean Ova and Larvæ.

Journ. Mar. Biol. Assoc. New Series. Vol. IX, No. 1. 1910.

Heinen, A. Die planktonische Fischeier und Larven der Ostsee.

Wiss. Meeresunters. Abt. Kiel. N.F. 14 Bd. 1912.

Ноєк, P. P. C. Les Clupéides (le Hareng excepté) et leurs migrations.

Rapp. et. Proc. Verb. Explor. Mer. Vol. XVI. 1913.

Johansen, A. C. Bericht über die Eier, Larven und älteren Stadien der Pleuronectiden in der Ostsee.

Rapp. et Proc. Verb. XII. 1910. 
Johansen, A. C. Zweiter Bericht über die Eier, Larven und älteren Stadien der Pleruonectiden in der Ostsee.

Rapp. et Proc. Verb. XIII. 1911.

Kramp, P. L. Report on the Fish Eggs and Larvæ collected by the Danish Research Steamer Thor in the Langelandsbelt in 1909.

Medd. Komm. f. Havund. Serie Fiskeri. Bd. IV, No. 5. 1913.

Kyle, H. M. Heterosomata.

Report on the Danish Oceano. Exped. 1908-1910 to the Mediterranean and Adjacent Seas. No. 2. 1913.

Lübbert, H. Was ist eine Sardine? Der Fischerbote. VI. Jahrg., Nr. 4. 1914.

McIntosh. On a young stage of Gadus luscus with bold transverse bars of pigment.

Ann. Mag. Nat. Hist. London. 3. 1909.

Murray, Sir J., and HJort, J. The Depths of the Ocean. London, 1912.

Petersen, C. G. J. On the Larval and Post-larval Stages of some Pleuronectidæ (Zeugopterus, Arnoglossus and Solea).

Medd. Havunders. Serie Fiskeri. 3. No. 1. 1909.

Redeke, H. C. Bericht über die Holländischen Arbeiten zur Naturgeschichte der Gadiden in den Jahren 1902 bis 1906.

Rapp. et Proc. Verb. Explor. Mer. X. 1909.

Scotт, A. On Pelagic Fish Eggs collected off South-West of Isle of Man.

Rep. Lancs. Sea Fisheries Laboratory. No. XXI. 1913.

Shann, E. Some notes on the Life History and Rate of Growth in Gobius minutus.

Ann. Mag. Nat. Hist. London. 5. 1910.

Storrow, B. The Spawning of the Whiting.

Report Dove Marine Laboratory. New Series, II. 1913.

Sund, O., and Koefoed, E. Undersökelser over Brislingen i Norske Farvande.

Særtryk av " Aarsberetning vedkommende Norges Fiskerier." Bergen, 1911.

Sund, O. Brislingen. The Sprat.

Rep. on Norwegian Fishery and Mar. Invest. Vol. II. No. 1. 1909.

Tesch, J. J. Eier und Larven einiger im Frühjahr laichenden Fische besonders der Südlichen Nordsee.

Helder Verh. Onderz. Zee. 2. 1909.

Tesch, J. J. Weitere Untersuchungen über das Laichen einiger Nutzfische besonders der Südlichen Nordsee.

Rapp. en Verhand. Rijksinst. v. Visscherijonderzoek. Deel I, Afl. 1. 1913.

Wollaston, H. J. Buchanan. Report on the Results of the Fish-Egg Cruise made by the S.S. Huxley in June, 1909. Internat. Fish. Investigations. Marine Biol. Assoc. Report III, 1906-8 (Cd. 5546). 1911. 